\title{
Mariana Spitz
}

\section{Mutações da glicocerebrosidase em pacientes com doença de Parkinson}

Tese apresentada à Faculdade de Medicina da Universidade de São Paulo, para obtenção do Título de Doutor em Ciências

Área de concentração: Neurologia Orientador: Prof. Dr. Egberto Reis Barbosa

São Paulo 
Para os meus pais, pelo amor que sempre me deram e pelo estímulo para a realização desta tese. 


\section{AGRADECIMENTOS}

Ao Prof. Dr. Egberto Reis Barbosa, o meu sincero agradecimento pela orientação recebida ao longo da elaboração desta tese e pelo indubitável crescimento profissional que me proporcionou.

A Roberto Rozenberg, do Laboratório de Genética Molecular do Instituto de Biologia da USP, sem o qual este trabalho não poderia ter sido realizado, pela paciência com que me orientou na introdução às técnicas laboratoriais de processamento de material genético.

À Prof ${ }^{\mathrm{a}}$ Lygia Veiga Pereira, do Laboratório de Genética Molecular do Instituto de Biologia da USP, que gentilmente cedeu as instalações para que parte do projeto fosse realizada, além de participar ativamente na construção intelectual do projeto.

A Alice Estevo Dias, Maira Tonidandel Barbosa, Hsin Fen Chien e Aline Mizuta Korozoski Kanashiro, pelo estímulo e amizade.

À minha irmã Lidia, presente em todos os momentos, que me auxiliou na revisão desta tese utilizando seus conhecimentos de informática.

Aos pacientes do ambulatório de Distúrbios do Movimento do HCFMUSP, que generosamente aceitaram participar deste projeto. 
Aos voluntários que concordaram em integrar este estudo como grupo controle, pelo seu altruísmo.

A Alexandre Pieri, pela ajuda prática, incentivo e amizade. 
A doença é muito antiga e nada sobre ela mudou. Somos nós que mudamos, à medida que aprendemos a reconhecer o que era previamente imperceptível.

Jean-Martin Charcot 


\section{NORMALIZAÇÃO ADOTADA}

Esta tese está de acordo com as seguintes normas, em vigor no momento desta publicação:

Referências: adaptado de International Committee of Medical Journals Editors (Vancouver)

Universidade de São Paulo. Faculdade de Medicina. Serviço de Biblioteca e Documentação. Guia de apresentação de dissertações, teses e monografias. Elaborado por Anneliese Carneiro da Cunha. Maria Julia de A. L. Freddi. Maria F. Crestana, Marinalva de Souza Aragão, Suely Campos Cardoso, Valéria Vilhena. $2^{\mathrm{a}}$ ed. São Paulo: Serviço de Biblioteca e Documentação; 2005.

Abreviaturas dos títulos dos periódicos de acordo com List of Journals Indexed in Index Medicus. 


\section{SUMÁRIO}

Lista de abreviaturas

Lista de figuras

Lista de tabelas

Resumo

Summary

Apresentação

1.Introdução

1.1.A doença de Parkinson no século XXI...................................................... 1

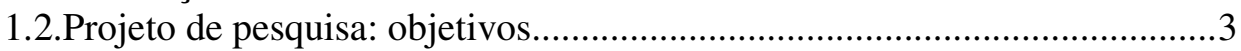

2.Revisão de literatura

2.1.Sobre a doença de Parkinson: aspectos gerais............................................. 4

2.2.Doença de Parkinson: epidemiologia..........................................................6

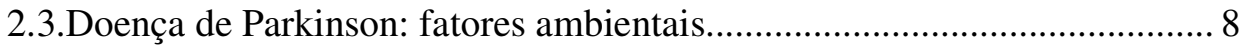

2.4.Genética da doença de Parkinson: os PARK.............................................. 10

2.5.Fisiopatologia da doença de Parkinson: visão atual.................................... 21

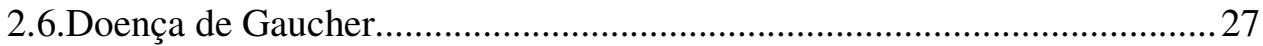

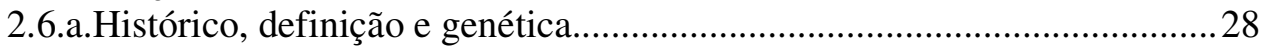

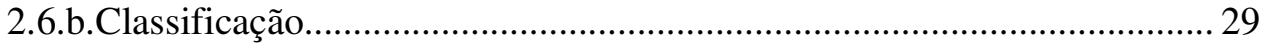

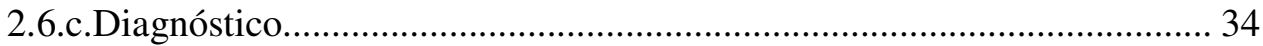

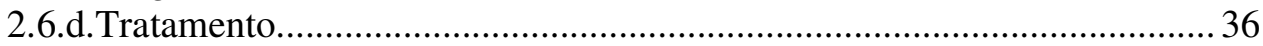

2.7.Associação entre doença de Parkinson e doença de Gaucher...................... 38

2.7.a.Parkinsonismo e doença de Gaucher - literatura mundial........................ 39

2.7.b.Parkinsonismo em pacientes com DG - experiência do HCFMUSP...... 42

2.7.c.Mutações da GBA em pacientes com DP.............................................. 46

3.Métodos

3.1.Da seleção de pacientes e controles............................................................51

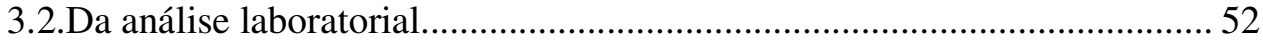

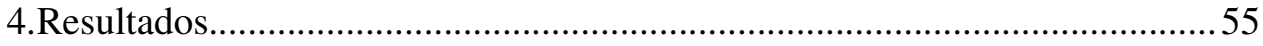

5.Discussão

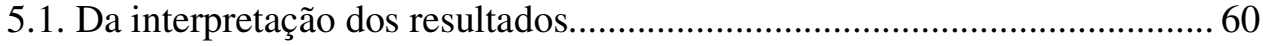

5.2. Da associação DP x DG - Fisiopatologia ................................................69

5.3. Das descobertas genéticas na doença de Parkinson.................................... 72

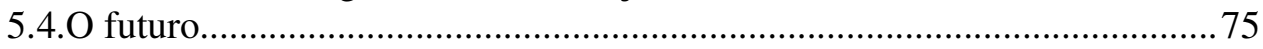

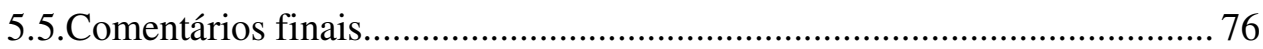

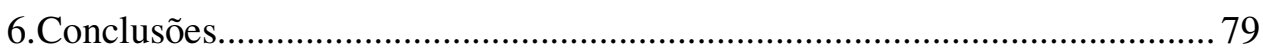

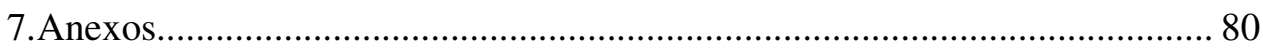

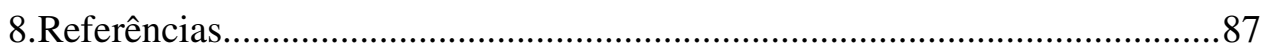




\section{LISTA DE ABREVIATURAS}

DP

DG

GBA

et al.

HCFMUSP
Doença de Parkinson

Doença de Gaucher

Gene da glicocerebrosidase

e outros

Hospital das Clínicas da Faculdade de Medicina da Universidade de São Paulo 


\section{LISTA DE FIGURAS}

Figura 1 - Representação esquemática do sistema ubiquitina-proteassomo de

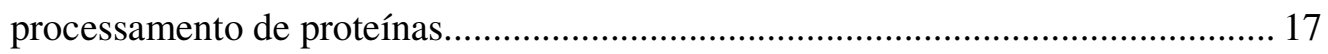

Figura 2 - Processos celulares associados à patogênese da doença de Parkinson...27

Figura 3 - Via de metabolismo lipídico..................................30

Figura 4 - Histopatologia do baço: paciente com doença de Gaucher e

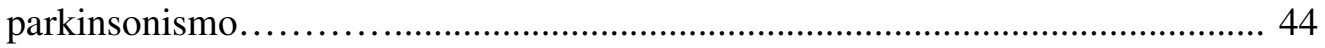

Figura 5 - Distribuição dos pacientes com doença de Parkinson por idade de início

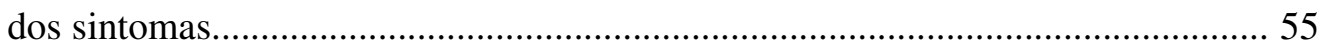

Figura 6 - História familiar de doença de Parkinson nos pacientes estudados..... 56

Figura 7 - Sintoma inicial da doença de Parkinson nos pacientes estudados..........56 


\section{LISTA DE TABELAS}

Tabela 1 - Principais formas hereditárias monogênicas de parkinsonismo

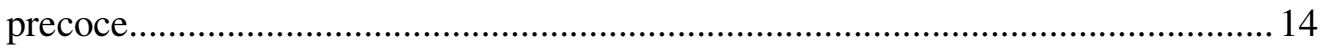

Tabela 2 - Formas clínicas da doença de Gaucher............................................ 32

Tabela 3 - Estudos sobre mutações da glicocerebrosidase em pacientes com doença

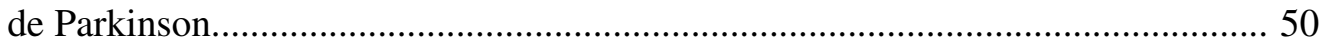

Tabela 4 - Estratégias de detecção das mutações analisadas.............................. 54

Tabela 5 - Características dos 65 pacientes do estudo........................................ 57-58

Tabela 6 - Perfil dos pacientes com doença de Parkinson carreadores de mutações da

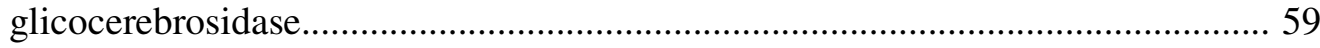




\section{RESUMO}

Spitz M. Mutações da glicocerebrosidase em pacientes com doença de Parkinson [tese]. São Paulo: Faculdade de Medicina, Universidade de São Paulo; 2006. 96p.

Introdução: A doença de Parkinson é uma enfermidade neurodegenerativa decorrente da perda de neurônios dopaminérgicos na substância negra, principalmente, e em outras regiões cerebrais. Caracteriza-se clinicamente por tremor, rigidez, bradicinesia e instabilidade postural. O tratamento é sintomático e consiste essencialmente na reposição da dopamina deficiente. A etiologia da doença de Parkinson ainda não é conhecida, mas os recentes avanços da Neurologia trouxeram novos conhecimentos acerca dos mecanismos fisiopatológicos envolvidos. Disfunção mitocondrial, estresse oxidativo e degradação de proteínas são alguns dos processos celulares que foram relacionados à degeneração dos neurônios dopaminérgicos. O campo da genética da doença de Parkinson tem recebido atenção especial na última década, graças à descoberta de vários genes associados ao desenvolvimento da doença. Um fator de risco genético recentemente descrito é a presença de mutações no gene da glicocerebrosidase, uma enzima lisossomal cuja deficiência resulta na doença de Gaucher. Apesar de a maioria dos estudos já publicados terem confirmado esta associação, um trabalho mais recente da Noruega não encontrou significância estatística ao analisar a presença destas mutações em pacientes com doença de Parkinson, tornando o assunto ainda controverso. Objetivo: Pesquisar a presença de mutações da glicocerebrosidase em pacientes com diagnóstico de doença de Parkinson no Brasil, acompanhados no ambulatório de 
Distúrbios do Movimento do Hospital das Clínicas da Faculdade de Medicina da Universidade de São Paulo e correlacionar tais achados com estudos recémpublicados que analisaram esta associação em outras populações em âmbito mundial, além de descrever possíveis características dos pacientes portadores de mutações que os diferenciem de não portadores. Métodos: Foram incluídos no estudo 65 pacientes com o diagnóstico de doença de Parkinson e idade de início da doença inferior ou igual a 55 anos e 267 controles sem a doença, emparelhados para sexo e idade. Foi realizada análise genética de material obtido a partir de raspagem da mucosa oral destes indivíduos, tendo sido pesquisadas as três mutações da glicocerebrosidase mais comuns na população brasileira: N370S, L444P e G377S. Resultados: Em dois dos 65 pacientes e em nenhum dos 267 controles foram identificadas mutações no gene da glicocerebrosidase. Os dois pacientes carreadores de mutações (L444P em um e L444P + E326K em outro) apresentavam quadro clínico indistinguível dos demais pacientes com doença de Parkinson não portadores das mutações. Conclusões: Foi observada uma associação estatisticamente significativa $(\mathrm{P}=0,0379$, teste exato de Fisher) entre doença de Parkinson e mutações da glicocerebrosidase na nossa população. A prevalência de mutações da glicocerebrosidase neste grupo de pacientes foi maior do que a esperada para a população geral, porém menor do que a encontrada em estudos internacionais previamente publicados. Espera-se que a identificação desta nova associação permita uma maior compreensão dos mecanismos subjacentes à doença de Parkinson e que em um futuro próximo possa propiciar o desenvolvimento de novas estratégias terapêuticas.

Descritores: Doença de Parkinson/genética, glucosilceramidase, Doença de Gaucher. 


\section{SUMMARY}

Spitz M. Glucocerebrosidase mutations in Parkinson's disease patients [thesis]. São Paulo: "Faculdade de Medicina, Universidade de São Paulo"; 2006. 96p.

Introduction: Parkinson's disease is a neurodegenerative disorder due to the loss of dopaminergic neurons in the substantia nigra, primarily, and in other brain regions. It is clinically characterized by tremor, rigidity, bradykinesia and postural instability. Treatment is symptomatic and consists essentially in replacing the deficient dopamine. The etiology of Parkinson's disease remains unknown, but recent advances in Neurology have provided data concerning the pathophysiological mechanisms involved. Mithocondrial dysfunction, oxidative stress and protein degradation are some of the cellular processes that have been linked to dopaminergic neurons degeneration. The field of genetics in Parkinson's disease has gained special attention in the past decade, thanks to the discovery of several genes associated with the development of the disease. A recently described genetic risk factor for Parkinson's disease is the presence of glucocerebrosidase gene mutations. Glucocerebrosidase is a lysosomal enzyme which is deficient in Gaucher disease. Although most studies published to date have confirmed such association, a recent article from Norway could not find statistical significance when Parkinson's disease patients were analyzed for glucocerebrosidase mutations, generating controversy. Objective: To search for glucocerebrosidase mutations in Parkinson's disease patients in Brazil, followed at the Movement Disorders Division at Hospital das Clínicas, University of São Paulo Medical School, and correlate these findings with 
recently published studies which evaluated this association in other populations worldwide, besides describing possible features of patients carrying the mutations that may help differentiating them from non-carriers. Methods: Sixty five patients diagnosed with Parkinson's disease, with disease onset before age 55, and 267 age and sex-matched controls were included in the study. DNA analysis of the three most common glucocerebrosidase mutations in the Brazilian population, N370S, L444P and G377S, was performed utilizing samples obtained from mouth mucus. Results: Glucocerebrosidase gene mutations were identified in two of the 65 Parkinson's disease patients and in none of the 267 controls. The two patients who were carriers of mutations (one of them had L444P and the other L444P+E326K) had a clinical picture indistinguishable from the other Parkinson's disease non-carriers patients. Conclusion: A statistically significant association ( $\mathrm{P}=0,0379$, Fisher's exact test) between Parkinson's disease and glucocerebrosidase mutations was observed in our population. The prevalence of glucocerebrosidase mutations was higher than expected for the general population, though lower than reported in previous international studies. It is expected that the finding of this association will allow a better understanding of Parkinson's disease mechanisms and that in a near future it may help providing the development of new therapeutic strategies.

Descriptors: Parkinson disease/genetics, glucosylceramidase, Gaucher disease. 


\section{APRESENTAÇÃO}

Quando decidi me mudar para São Paulo em 2001, para fazer a residência em Neurologia na Escola Paulista de Medicina, jamais poderia imaginar que meu período nesta cidade se estenderia por mais de cinco anos. Apesar de saudosa de casa, no Rio de Janeiro, tomei a difícil - e hoje bem vejo acertada - decisão de prolongar minha permanência, tentando a pós-graduação na USP.

Após uma reunião com o Dr. Egberto Barbosa - então meu futuro orientador comecei a freqüentar o gigante Hospital das Clínicas da USP, especializando-me em um campo da Neurologia que atraiu minha atenção pela primeira vez ainda na faculdade - o de distúrbios do movimento.

Alguns meses após, o Dr. Egberto foi procurado por um biólogo do Instituto de Biologia da USP, Roberto Rozenberg, que durante a execução de seu projeto de doutorado acerca da doença de Gaucher no Brasil, havia se deparado com um interessante relato de literatura associando doença de Parkinson e mutações causadoras da doença de Gaucher, e buscava uma parceria para novas investigações sobre o assunto no Brasil.

Surgia assim meu projeto de doutorado, inicialmente intitulado "Síndrome parkinsoniana como manifestação da doença de Gaucher", ainda em 2004, e que evoluindo simultaneamente à literatura mundial, modificou seu foco e posteriormente seu título para "Mutações da glicocerebrosidase em pacientes com doença de Gaucher". O tema, bem definido pelo Dr. Egberto como "na crista da onda”, nos surpreendia a cada mês com novos artigos e descobertas, reforçando o valor da pesquisa. 
O trabalho consistia na pesquisa genética de determinadas mutações da doença de Gaucher em pacientes com doença de Parkinson. A coleta de material dos pacientes não ofereceu grandes desafios, pois todos se mostravam esperançosos de poder contribuir para novas descobertas.

A detecção de mutações no grupo de pacientes gerou em nós alívio e disposição para prosseguir.

Quando se passou à coleta de controles, atingi o ponto mais próximo da desistência. Por mais gentil e educada que fosse a abordagem, a resposta muitas vezes era ríspida e desconfiada. As recusas em participar se sucediam, rendendo novas manhãs e tardes de peregrinação pelos corredores do HCFMUSP. Muitas pessoas, à simples menção de ser o estudo de cunho genético, demonstravam preocupação de que o material pudesse ser usado indevidamente para cloná-las.

Em seguida, obtidas as amostras necessárias, fui desdobrada em neurologistapesquisadora-cientista e, devido à sobrecarga de trabalho para o Roberto, juntei-me a ele no processamento do material. O aprendizado das técnicas laboratoriais de manipulação e análise de DNA levou-me a um universo antes desconhecido e devo confessar que no início me mostrei deveras atrapalhada.

Por fim, com os resultados analisados, significância estatística confirmada e uma sensação de satisfação e dever cumprido, surgiu a esperança de que este pequeno, porém esforçado trabalho, possa contribuir para o desenvolvimento da ciência. 


\section{INTRODUÇÃO}

\subsection{A doença de Parkinson no século XXI}

Os recentes avanços da Neurologia trouxeram novos conhecimentos acerca dos mecanismos fisiopatológicos envolvidos na doença de Parkinson (DP). Disfunção mitocondrial, estresse oxidativo e processamento inadequado de proteínas são alguns dos processos celulares relacionados à degeneração de neurônios dopaminérgicos na substância negra.

O progresso em relação à patogênese da doença, no entanto, não foi acompanhado de avanços correspondentes na área da terapêutica. Utilizada inicialmente na década de 60, a levodopa, ainda que associada a uma série de efeitos colaterais a curto e longo prazo, revolucionou o tratamento da DP e permanece como a opção farmacológica mais eficaz ${ }^{1}$. A lógica consiste em corrigir a deficiência estriatal de dopamina própria da doença².

Neste contexto de descoberta de novas informações acerca da DP, tem papel de destaque o campo da Genética. Mutações genéticas relacionadas à doença, como Parkin, LRRK2, DJ1 e PINK1, surgem como termos correntes na descrição de casos de parkinsonismo, especialmente em pacientes com início precoce da doença e história familiar positiva.

Foi exatamente na área da Genética que uma das associações mais recentes e surpreendentes da DP, talvez pela falta inicial de um nexo lógico, foi descrita: a presença de mutações no gene da glicocerebrosidase (GBA) como um fator de risco para o desenvolvimento de parkinsonismo. Parkinsonismo conota uma constelação clínica que pode incluir tremor, rigidez, distúrbio de marcha e instabilidade postural e cuja principal causa é a DP. 
A glicocerebrosidase é a enzima lisossomal responsável pela lise de glicocerebrosídeos em glicose e ceramida. Mutações na GBA levam à redução da atividade da enzima e são responsáveis pela principal doença de depósito lisossomal, a doença de Gaucher (DG). A DG divide-se em três subtipos de acordo com a presença de sintomas neurológicos e sua gravidade. A DG tipo 1 é classicamente considerada não-neuronopática, mas vários relatos de literatura nas últimas décadas descreveram manifestações neurológicas nestes pacientes, tipicamente uma síndrome parkinsoniana. Com base nestes achados, associando doenças a princípio tão díspares, surgiu a idéia de pesquisar mutações da GBA em pacientes com DP. Até o momento foram publicados apenas alguns estudos sobre o assunto, a maioria demonstrando a presença da associação. Um deles encontrou, de forma surpreendente, uma freqüência significativa de mutações da GBA em pacientes com DP - cerca de $30 \%^{3}$. Outro artigo recentemente publicado, por sua vez, não conseguiu demonstrar significância estatística desta associação em uma população específica $^{4}$.

O mecanismo da associação entre DP e mutações da GBA ainda não foi elucidado, porém já existem teorias correlacionando mutações da GBA e formação de agregados de alfa-sinucleína, que são os constituintes principais dos corpos de Lewy, os marcadores patológicos da DP. Espera-se que a confirmação desta nova associação e investigações subseqüentes permitam uma maior compreensão dos mecanismos subjacentes à DP e que em um futuro próximo seja possível o desenvolvimento de novas estratégias terapêuticas.

Diante destes achados, o presente estudo teve como objetivo avaliar a associação entre DP e mutações da GBA em um grupo de pacientes brasileiros. 


\subsection{Projeto de pesquisa: Objetivos}

Os objetivos do presente estudo são:

1) Identificar, dentre um grupo de pacientes com diagnóstico de DP idiopática iniciada antes de 55 anos de idade, acompanhados no ambulatório de Distúrbios do Movimento do Hospital das Clínicas da Faculdade de Medicina da Universidade de São Paulo (HCFMUSP), aqueles portadores de mutação no gene da glicocerebrosidase, responsável pela DG;

2) Avaliar o impacto das mutações da GBA, um possível fator de risco hereditário para DP, na nossa população;

3) Correlacionar os achados na população brasileira com estudos realizados em outros países;

4) Discutir possíveis características clínicas que permitam a diferenciação de pacientes com DP carreadores e não carreadores das mutações avaliadas. 


\section{REVISÃO DE LITERATURA}

\subsection{Sobre a doença de Parkinson: aspectos gerais}

A DP foi descrita pela primeira vez por James Parkinson, então membro do Colégio Real de Cirurgiões, em 1817. Em seu ensaio, "An essay on the shaking palsy", o médico britânico, baseando-se em três pacientes por ele avaliados, em outros dois que tinha observado casualmente na rua e em outro não examinado pessoalmente ${ }^{5}$, descreve uma nova condição - a "paralisia agitans" - que caracteriza como:

"Involuntary tremulous motion, with lessened muscular power, in parts not in action and even when supported; with a propensity to bend the trunk forward, and to pass from a walking to a running pace the senses and intellect being uninjured". 6

["Movimento tremulante involuntário, com redução da força muscular, em partes que não estão em ação e mesmo quando com suporte, com propensão a inclinar o tronco para frente, e passar de um compasso de marcha para corrida, sem comprometimento dos sentidos e do intelecto"]

A DP constitui a segunda doença neurodegenerativa mais comum, sendo superada apenas pela doença de Alzheimer ${ }^{7,8,9,10}$. Decorre da perda progressiva de neurônios dopaminérgicos na substância negra, principalmente, e em outras regiões do cérebro $^{11}$. O quadro clínico torna-se evidente quando esta perda neuronal dopaminérgica ultrapassa aproximadamente 70 a $80 \%$ do total $^{12}$ e caracteriza-se por tremor de repouso, rigidez, bradicinesia e instabilidade postural. Tipicamente, o início da DP é assimétrico, insidioso e progressivo à medida que disfunção neuronal e morte celular levam a uma deleção profunda do neurotransmissor dopamina no striatum, um componente central dos gânglios da base que é responsável pela iniciação e controle dos movimentos ${ }^{13}$. Além destes denominados sintomas cardinais da doença, outras manifestações presentes ao longo da evolução da mesma, em maior ou menor grau, incluem: transtornos neuropsiquiátricos (como depressão e 
demência), disfunção autonômica (hipotensão postural, alterações esfincterianas, impotência) e sintomas sensitivos, como dor ${ }^{14}$. Estas manifestações não motoras da doença muitas vezes são subdiagnosticadas, dada a exuberância do quadro motor, mas do ponto de vista do paciente podem ser consideravelmente incapacitantes e levar a um comprometimento da qualidade de vida.

Tentativas de neuroproteção (prevenção de morte celular) e neurorrestauração (recuperação dos neurônios "doentes") estão sendo muito debatidas à medida que se avançam os conhecimentos sobre a $\mathrm{DP}^{10}$, mas até o momento não foi estabelecida uma estratégia para se interferir com a história natural da doença e impedir a progressão da mesma. No entanto, há quase meio século encontra-se disponível a levodopa, que constitui uma terapia sintomática eficaz, permitindo o controle de grande parte dos sintomas, especialmente no início da doença. A resposta à levodopa é esperada em 94 a 100\% dos pacientes ${ }^{15}$, sendo inclusive a ausência de uma resposta satisfatória a esta medicação considerada um sinal de alerta no diagnóstico diferencial com outras síndromes parkinsonianas ${ }^{16}$.

O uso de levodopa e, mais recentemente, de agonistas dopaminérgicos e drogas que inibem enzimas responsáveis pela metabolização da dopamina (monoaminoxidase-B, ou MAO-B, e catecol-O-metil-transferase, ou COMT), tiveram um impacto dramático na vida dos pacientes afetados pela DP através do benefício sintomático proporcionado. Baseando-se no princípio de repor o neurotransmissor deficiente na doença, o tratamento sintomático da DP representa um avanço, especialmente se considerarmos as poucas opções disponíveis para a terapêutica de outras doenças neurodegenerativas. Infelizmente, apesar de muito eficaz, a terapia com levodopa está associada a uma série de complicações a longo 
prazo, que podem ser tão incapacitantes quanto a própria doença, levando a um comprometimento da qualidade de vida ${ }^{17}$. Entre elas, têm destaque o "wearing off" (piora dos sintomas parkinsonianos antes da dose seguinte programada de levodopa) e as discinesias (movimentos involuntários induzidos por droga) ${ }^{18}$. Tal fato reforça a necessidade de, através de uma melhor compreensão da patogênese da doença, serem obtidas novas abordagens terapêuticas para a DP.

\subsection{Doença de Parkinson: epidemiologia}

A DP é observada em todos os países, grupos étnicos e classes sócioeconômicas ${ }^{19}$. Tem uma prevalência estimada de 150 a 200 por 100000 habitantes, representando uma das doenças neurológicas mais comuns ${ }^{20}$. Estima-se atualmente que a doença tenha uma prevalência de aproximadamente 3,3\% na população acima de 64 anos, segundo dados brasileiros ${ }^{21}$. Afeta aproximadamente um milhão de americanos e 1 a $2 \%$ daqueles acima de 60 anos de idade no mundo todo, estando associada a um risco de desenvolvê-la durante a vida de $2 \%$ e apresentando aumento da incidência com a idade. Acredita-se que o envelhecimento da população, fenômeno que vem sendo constatado em escala mundial, modifique de forma significativa essas estatísticas em um futuro próximo, devendo o número de pessoas afetadas triplicar nos próximos $50 \operatorname{anos}^{22}$.

Esses dados representam um impacto substancial, não só em termos individuais, já que a doença é progressiva e tende a gerar uma limitação significativa das atividades da vida diária, acarretando um impacto psicossocial que inclui desde comprometimento pessoal por dor, imobilidade e dependência progressiva até 
desemprego e problemas conjugais ${ }^{23}$, como em relação aos gastos com saúde pública $^{24}$. O início mais precoce da doença está relacionado a uma maior frequiência de desemprego, rompimento da estrutura familiar e percepção de estigmatização em relação aos casos de início mais tardio ${ }^{25}$.

A idade média de início da doença é de aproximadamente $55 \operatorname{anos}^{8}$, sendo porém mais precoce em casos de DP familiar e com componente genético. Os estudos divergem no que se refere ao acometimento preferencial por gênero, mas na maioria se observa um predomínio do sexo masculino, em uma taxa de 1,5:1 até 2:1 em relação ao sexo feminino ${ }^{9}$. Um estudo recente em 8 municípios italianos, por exemplo, mostrou que os homens têm uma chance duas vezes maior de desenvolver DP quando comparados às mulheres ${ }^{26}$. A razão para esta diferença não está esclarecida, apesar de ter sido sugerido um possível efeito neuroprotetor dos estrogênios $^{27}$.

Estudos de incidência de DP mostram que a taxa de ocorrência da doença aumenta significativamente após a quinta década. Um estudo da Califórnia ${ }^{9}$ de 2003 mostrou uma incidência anual de 12,3 por 100.000 na população geral, enquanto que para pessoas com mais de 50 anos a incidência foi de 44 por 100.000. A taxa de incidência da doença entre asiáticos parece ser menor do que em brancos e neste estudo em particular foi menor em negros do que em brancos. Nesta população avaliada, apenas cerca de $0,5 \%$ dos casos foram diagnosticados antes de 40 anos e 3,4\% antes de 50 anos, demonstrando mais uma vez a influência da idade na incidência da doença. Em uma análise dos estudos epidemiológicos acerca da DP já publicados, Twelves et al ${ }^{28}$ mostraram uma incidência média de 16 a 19 por 100.000 
por ano, com uma taxa significativamente maior em homens (1,5 a 2 vezes mais). $\mathrm{O}$ pico de incidência foi de 70 a 79 anos.

Em um estudo de prevalência de DP realizado em Londres ${ }^{29}$ em 1997, a taxa de DP idiopática foi de 128 por 100000, mas os autores defendem em seu artigo que a doença não teria sido diagnosticada em até 10 a $20 \%$ dos casos, o que aumentaria este número para cerca de 200 por 100.000 . Os casos não diagnosticados muitas vezes devem-se à não procura de auxílio médico por parte dos pacientes, que desta forma não são incluídos em estudos clínicos realizados em âmbito hospitalar²7.

Em um trabalho nacional publicado em 2006, realizado em Bambuí ${ }^{21}$, cidade no interior de Minas Gerais, a taxa de prevalência de DP foi de 3,3\%, também sendo observado aumento acentuado com a idade, em concordância com a literatura.

\subsection{Doença de Parkinson: fatores ambientais}

Muitos fatores ambientais já foram associados ao desenvolvimento da DP e parkinsonismo, mas nenhum foi definido de forma conclusiva como causador da doença $^{30}$. Dentre as exposições ambientais e ocupacionais já implicadas na etiologia da DP, pode-se citar: ingestão de água de poço, pesticidas, herbicidas, vida rural, exposição a certos metais, campos magnéticos e mineração ${ }^{22}$, entre outros. A hipótese mais aceita atualmente é que ocorra uma interação entre fatores ambientais e fatores genéticos no desencadeamento da doença.

A teoria da influência dos fatores ambientais na gênese da DP foi fortalecida na década de oitenta, quando jovens usuários de drogas da área da baía de São Francisco, nos Estados Unidos, injetaram inadvertidamente um subproduto da 
fabricação da meperidina, o MPTP (1-metil-4-fenil 1,2,3,6-tetraidropiridina) e desenvolveram um quadro muito semelhante à $\mathrm{DP}^{30,31}$. O MPTP induz toxicidade através de sua conversão pela MAO-B em astrócitos para seu metabólito ativo $\mathrm{MPP}^{+}$, que é então seletivamente captado por neurônios dopaminérgicos, causando um defeito no complexo I (NADH CoQ redutase) da cadeia transportadora de elétrons mitocondrial, resultando em degeneração neuronal ${ }^{12,30}$. Esta constatação permitiu o posterior desenvolvimento de modelos experimentais de DP em animais, que ainda são muito utilizados. No entanto, há diferenças importantes entre a DP idiopática e o parkinsonismo induzido por MPTP. Talvez a mais notável seja a ausência de corpos de Lewy, considerados como os marcadores patológicos da DP, neste último ${ }^{12}$.

Em um estudo italiano ${ }^{26}$ de 2003 , um maior risco para DP foi observado em indivíduos de idade mais avançada, do sexo masculino, sem prática prévia de tabagismo e expostos a pesticidas. A hipótese mais simples para a associação entre pesticidas e DP é que os pesticidas ou seus metabólitos sejam diretamente tóxicos para a mitocôndria, cuja disfunção é considerada atualmente como um dos eventoschave na fisiopatologia da DP. Quanto ao tabagismo, observa-se uma associação inversa com a ocorrência de DP, porém a base biológica subjacente ainda não é bem compreendida. Uma das explicações atribui a menor incidência de DP entre tabagistas ao fato de a nicotina ser capaz de estimular a liberação de dopamina e agir como antioxidante ${ }^{27}$. O uso de pesticidas como possível fator de risco para a DP também foi avaliado por Firestonde et al. em $2005^{32}$. Neste estudo caso-controle de incidência de DP em Washington, nos Estados Unidos, os achados não forneceram evidências significativas para a hipótese de que a exposição a pesticidas seja um fator de risco para a DP. Jankovic, em 2005, analisou a possível relação da toxicidade do 
manganês e exposição a soldagem como fatores de risco em potencial para o desenvolvimento de parkinsonismo e concluiu que não há evidências convincentes de que a soldagem seja um fator de risco significativo para a DP ou que o parkinsonismo induzido por manganês compartilhe qualquer mecanismo patogênico com a $\mathrm{DP}^{22}$.

\subsection{Genética da doença de Parkinson: os PARK}

Historicamente a DP era considerada como uma doença não-genética. Estudos em gêmeos eram inconsistentes com a hipótese de um componente genético, apesar de já terem sido observadas concentrações de casos em uma mesma família ${ }^{33}$. Em artigo de 2004, Wirdefeldt et al. estudaram a concordância de DP em gêmeos na Suécia $^{34}$. Os autores referem no trabalho que estudos prévios com gêmeos registravam baixa taxa de concordância, que não diferia no caso de os irmãos serem mono ou heterozigotos, e concluem a partir dos seus achados que os efeitos genéticos são de pouca importância na $\mathrm{DP}$, propondo como uma das explicações a preponderância da interação gene-ambiente na determinação da doença. De fato, apesar do relato de 10 a $30 \%$ dos pacientes com DP de um parente de primeiro grau com parkinsonismo, a agregação familiar foi geralmente atribuída a exposições compartilhadas de um ambiente comum ${ }^{13}$.

As novas descobertas na área da Genética da DP trouxeram contribuições inestimáveis à compreensão da fisiopatologia da doença. Ironicamente, conforme observado por Farrer, “a DP, doença aparentemente não-genética, pode ser uma das primeiras a ser prevenida através da compreensão genética de suas causas moleculares" $" 13$. 
Na última década, uma série de mutações foram descritas em famílias com DP, com um padrão mendeliano de herança. A identificação de várias formas monogênicas estabeleceram a DP como um distúrbio de movimento com uma origem genética considerável, em pelo menos um subgrupo de pacientes. Todas as formas monogênicas combinadas explicam apenas cerca de $20 \%$ dos casos de DP de início precoce e menos de $3 \%$ de início tardio ${ }^{35}$. Quanto mais precoce a idade de início da DP, maior a probabilidade de que os fatores genéticos tenham um papel dominante ${ }^{36}$. Apesar de relativamente incomuns dentro da população total de pacientes com DP, as formas genéticas da doença forneceram um caminho para estudo e identificação dos mecanismos que levam ao desenvolvimento da doença, não só nos casos genéticos, mas também nos esporádicos.

O ano de 1997 trouxe uma mudança no cenário caracterizado pela idéia de a DP ser uma doença "não-genética". Polymeropoulos et al. descreveram a primeira mutação em uma família de Contursi com DP, no gene da alfa-sinucleína ${ }^{37}$. Este achado, de importância considerável por si só, recebeu uma valorização adicional, quando no mesmo ano, um grupo de pesquisadores do Reino Unido conseguiu identificar justamente a alfa-sinucleína como o principal componente dos corpos de Lewy ${ }^{38,39}$. Dessa forma, o elo entre Genética e a fisiopatologia da doença lançou novas esperanças de finalmente se desvendar os mecanismos moleculares que levavam à DP. A esta descoberta inicial, se seguiram outras, de valor equivalente. Em um intervalo de menos de 10 anos, as descobertas de genes associados à DP cresceram de forma exponencial, a ponto que se torna difícil hoje falar sobre a DP sem se fazer referência aos aspectos genéticos da doença. 
Até o momento 11 loci genéticos foram identificados na DP, tendo sido denominados PARK1 a PARK11. Cada PARK representa uma região genômica ligada, com graus variáveis de evidência, a "doenças tipo DP" "doenças", pois será comentado a seguir que o espectro de manifestações das formas genéticas de DP muitas vezes se estende além das características definidoras da doença de tremor, rigidez, bradicinesia e instabilidade postural. Dois desses 11 loci genéticos foram posteriormente descartados: a família originalmente mapeada como PARK4 na realidade mapeava como PARK1 e o PARK9 não é de fato um locus de DP. Dos nove loci remanescentes, foram identificados os seguintes genes: PARK1 alfa-sinucleína, PARK2 - parkin, PARK5 - UCHL1, PARK6 - PINK1, PARK7 DJ-1 e PARK8 - LRRK2. Certamente genes adicionais serão identificados em um futuro próximo, fornecendo novas peças ao "quebra-cabeça etiológico" da $\mathrm{DP}^{33}$.

Apesar de somente uma pequena proporção dos casos de DP (estima-se que 10\%) serem causados por mutações genéticas com alta penetrância, a identificação destes genes teve um impacto significativo na compreensão dos mecanismos que determinam a degeneração dopaminérgica ${ }^{41}$. Esses mecanismos envolvem a agregação de proteínas, déficit de degradação de substratos pelo sistema ubiquitinaproteassomo, disfunção mitocondrial e estresse oxidativo, temas que serão abordados no próximo tópico. Além disso, como tanto anseiam os pacientes, espera-se que, em médio ou longo prazo, a estas descobertas genéticas corresponda um avanço em termos de estratégias terapêuticas para a doença.

A seguir serão descritas as principais descobertas relacionadas à genética da DP. A Tabela 1 resume as principais características da doença no caso de cada uma das mutações. Os PARK 1, 5 e 8 têm transmissão autossômica dominante. Os PARK 
2, 6 e 7 são formas autossômicas recessivas, relativamente raras, associadas à perda de função, e resultam em DP com idade de início precoce (tipicamente abaixo de 40 anos), com progressão lenta e boa resposta à levodopa ${ }^{13}$.

*PARK1 - Alfa-sinucleína

Em 1996, Polymeropoulos et al. mapearam o defeito genético responsável pela DP em uma família de Contursi, no sul da Itália, no braço longo do cromossomo 4 (4q21-23). Um ano depois, o mesmo grupo descobriu uma mutação (A53T) no gene da alfa-sinucleína como causa genética de DP familiar, neste grupo e em várias famílias gregas com $\mathrm{DP}^{12,37}$. O fenótipo clínico era semelhante ao da DP clássica, porém com início mais precoce da doença (quarta década, em média), tendo já sido descritas algumas características atípicas, incluindo demência proeminente, hipoventilação e distúrbios autonômicos graves $^{23}$. Mutações no gene da alfasinucleína causam DP em um pequeno número de indivíduos com DP familiar ${ }^{42}$.

PARK1 envolve mutações no gene da alfa-sinucleína, como A53T e A30P. Multiplicações no gene da alfa-sinucleína "nativa" também foram associadas à DP, tendo sido identificada triplicação do gene em uma família com DP autossômica dominante e duplicação em outra com DP de início precoce.

Mutações no gene da alfa-sinucleína resultam em níveis aumentados de protofibrilas, que são consideradas a forma mais tóxica da proteína. As mutações A53T (da família de Contursi) e a A30P (identificada em uma família de origem alemã $\tilde{a}^{2}$ promovem a formação de protofibrilas. A mutação A30P, além disso, potencializa a toxicidade da dopamina, aumentando a lesão mediada por radicais livres e a morte celular ${ }^{43}$. 


\begin{tabular}{|c|c|c|c|c|c|}
\hline PARK & $\begin{array}{c}\text { Gene } \\
\text { envolvido; } \\
\text { cromossomo }\end{array}$ & $\begin{array}{l}\text { Forma de } \\
\text { transmissão }\end{array}$ & $\begin{array}{l}\text { Idade de } \\
\text { início }\end{array}$ & Quadro clínico & $\begin{array}{l}\text { Alterações } \\
\text { patológicas }\end{array}$ \\
\hline PARK1 & $\begin{array}{l}\text { Alfa- } \\
\text { sinucleína; } \\
4 \mathrm{q}\end{array}$ & $\begin{array}{c}\text { Autossômica } \\
\text { dominante }\end{array}$ & $\begin{array}{l}\text { Em média, } \\
\text { quarta } \\
\text { década }\end{array}$ & $\begin{array}{c}\text { Parkinsonismo } \\
\text { responsivo à } \\
\text { levodopa, } \\
\text { associado a } \\
\text { declínio } \\
\text { cognitivo, } \\
\text { disfunção } \\
\text { autonômica e } \\
\text { demência. }\end{array}$ & $\begin{array}{l}\text { Típicas, com } \\
\text { corpos de Lewy; } \\
\text { perda neuronal } \\
\text { proeminente } \\
\text { nigral e no } \\
\text { hipocampo. }\end{array}$ \\
\hline PARK2 & Parkin, 6q & $\begin{array}{l}\text { Autossômica } \\
\text { recessiva }\end{array}$ & $\begin{array}{c}\text { Maioria } \\
\text { antes de } 40 \\
\text { anos } \\
\text { (média=30 } \\
\text { anos) }\end{array}$ & $\begin{array}{l}\text { Progressão lenta, } \\
\text { discinesias } \\
\text { precoces, pode } \\
\text { haver disfunção } \\
\text { autonômica, } \\
\text { hiperreflexia, } \\
\text { instabilidade } \\
\text { postural precoce. } \\
\text { Resposta a doses } \\
\text { baixas de } \\
\text { levodopa. }\end{array}$ & $\begin{array}{l}\text { Predomínio de } \\
\text { perda neuronal } \\
\text { nigral e gliose } \\
\text { sem corpos de } \\
\text { Lewy (já } \\
\text { descritos em } \\
\text { alguns casos). }\end{array}$ \\
\hline PARK5 & $\mathrm{UCH}-\mathrm{L} 1,4 \mathrm{p}$ & $\begin{array}{c}\text { Autossômica } \\
\text { dominante }\end{array}$ & $\begin{array}{l}55-58 \text { anos; } \\
\text { início tardio }\end{array}$ & DP esporádica & $\begin{array}{l}\text { Indeterminada; a } \\
\text { proteína UCH- } \\
\text { L1 é um } \\
\text { componente } \\
\text { proeminente dos } \\
\text { corpos de Lewy }\end{array}$ \\
\hline PARK6 & PINK1, 1p & $\begin{array}{l}\text { Autossômica } \\
\text { recessiva }\end{array}$ & $\begin{array}{l}\text { Entre } 20 \text { e } \\
50 \text { anos }\end{array}$ & $\begin{array}{c}\text { Progressão lenta, } \\
\text { resposta a doses } \\
\text { baixas de } \\
\text { levodopa, pode } \\
\text { haver distonia } \\
\text { focal e demência. }\end{array}$ & Desconhecida \\
\hline PARK7 & $\mathrm{DJ}-1,1 \mathrm{p}$ & $\begin{array}{l}\text { Autossômica } \\
\text { recessiva }\end{array}$ & $\begin{array}{c}\text { Geralmente } \\
\text { antes de } 40 \\
\text { anos (20-40 } \\
\text { anos) }\end{array}$ & $\begin{array}{c}\text { Progressão lenta, } \\
\text { maior frequiência } \\
\text { de distúrbios } \\
\text { psiquiátricos e } \\
\text { distonia } \\
\end{array}$ & Desconhecida \\
\hline PARK8 & LRRK2, 12q & $\begin{array}{c}\text { Autossômica } \\
\text { dominante }\end{array}$ & $\begin{array}{c}\text { Maioria } \\
\text { acima de } 50 \\
\text { anos (50-70 } \\
\text { anos) }\end{array}$ & $\begin{array}{l}\text { Típico de DP } \\
\text { clássica }\end{array}$ & $\begin{array}{c}\text { Variáveis: } \\
\text { corpos de Lewy, } \\
\text { emaranhados } \\
\text { neurofibrilares, } \\
\text { perda neuronal } \\
\text { nigroestriatal. }\end{array}$ \\
\hline
\end{tabular}

Tabela 1 - Principais formas hereditárias monogênicas de parkinsonismo precoce 
O gene da alfa-sinucleína codifica uma proteína pré-sináptica envolvida na plasticidade neuronal ${ }^{37}$, expressa ao longo do cérebro, que tem papel também no aprendizado, na dinâmica de vesículas e na síntese de dopamina ${ }^{13}$. Ela foi originalmente identificada como a proteína precursora do componente não-(beta) amilóide nas placas amilóides da doença de Alzheimer ${ }^{37}$.

Em seu artigo, Polymeropoulos et al. enfatizam a importância da sua descoberta ao comentar que "apesar de a mutação no gene da alfa-sinucleína não ser responsável pela maioria de casos esporádicos e familiares de DP, pode sê-lo por uma proporção significativa de famílias com DP de início precoce caracterizadas por uma herança muito penetrante, autossômica dominante”.

Até 1997, a composição bioquímica dos filamentos dos corpos de Lewy, o marcador histopatológico da DP, permanecia desconhecida. Em 1912, Friederich Lewy havia descrito as inclusões características da DP, que posteriormente receberam o nome em sua homenagem. Em 1960, a microscopia eletrônica foi usada para mostrar que tais inclusões eram compostas de filamentos anormais ${ }^{12}$. No ano de 1997, Spillantini et al. identificaram uma forte imunorreatividade dos corpos de Lewy para a alfa-sinucleína, criando, desta forma, uma ligação com a descoberta genética $^{38}$. Assim sendo, foi determinado que a alfa-sinucleína era o principal constituinte dos corpos de Lewy, tanto em casos genéticos como esporádicos da DP. Foi a primeira prova inequívoca de que a genética tinha um papel valioso na DP, o que contribuiu para estimular a pesquisa na área ${ }^{33}$.

No entanto, ainda não se definiu se os agregados de alfa-sinucleína têm um papel causal direto na DP ou se apenas representam um marcador do processo patogênico subjacente. 
*PARK2 - Parkin

Um ano após a descoberta das mutações no gene da alfa-sinucleína, mostrou-se que mutações no gene parkin causavam uma forma autossômica recessiva de DP. PARK2 é a causa monogênica mais comum de parkinsonismo de início precoce responsável por cerca de metade dos casos de DP autossômica recessiva de início antes dos $40 \operatorname{anos}^{31}$ - e deve-se a mutações no cromossomo $6^{23}$.

Em 1998, Kitada et al. descreveram mutações neste novo gene da DP e nomearam o produto da proteína “parkin”. Essas mutações estariam ligadas a doença de início precoce e neurodegeneração na substância negra sem formação de corpos de Lewy ${ }^{44}$.

Em 2000, Shimura et al. verificaram que parkin é uma ubiquitina E3 ligase $^{45}$ (isto é, tem a função de conjugar a ubiquitina às proteínas para torná-las alvo de degradação ${ }^{13}$ ), o que implicou a disfunção do sistema ubiquitina-proteassomo na patogênese da $\mathrm{DP}^{31}$. A ubiquitina é um pequeno modificador que se liga a determinadas proteínas, formando uma cadeia que se torna um sinal de degradação, indicando que tal proteína deve ser atacada pelo proteassomo, que por sua vez é considerado a "lixeira" da célula ${ }^{45}$ (Figura 1). Proteassomos são proteases catalíticas e as principais enzimas responsáveis pela degradação de proteínas na célula. Medeiam a remoção de proteínas mutantes, mal dobradas, oxidadas e anormais; sua inibição desencadeia acúmulo e agregação de proteínas, formação de corpos de inclusão, interrupção de atividades inter e intracelulares e finalmente morte celular ${ }^{46}$. 


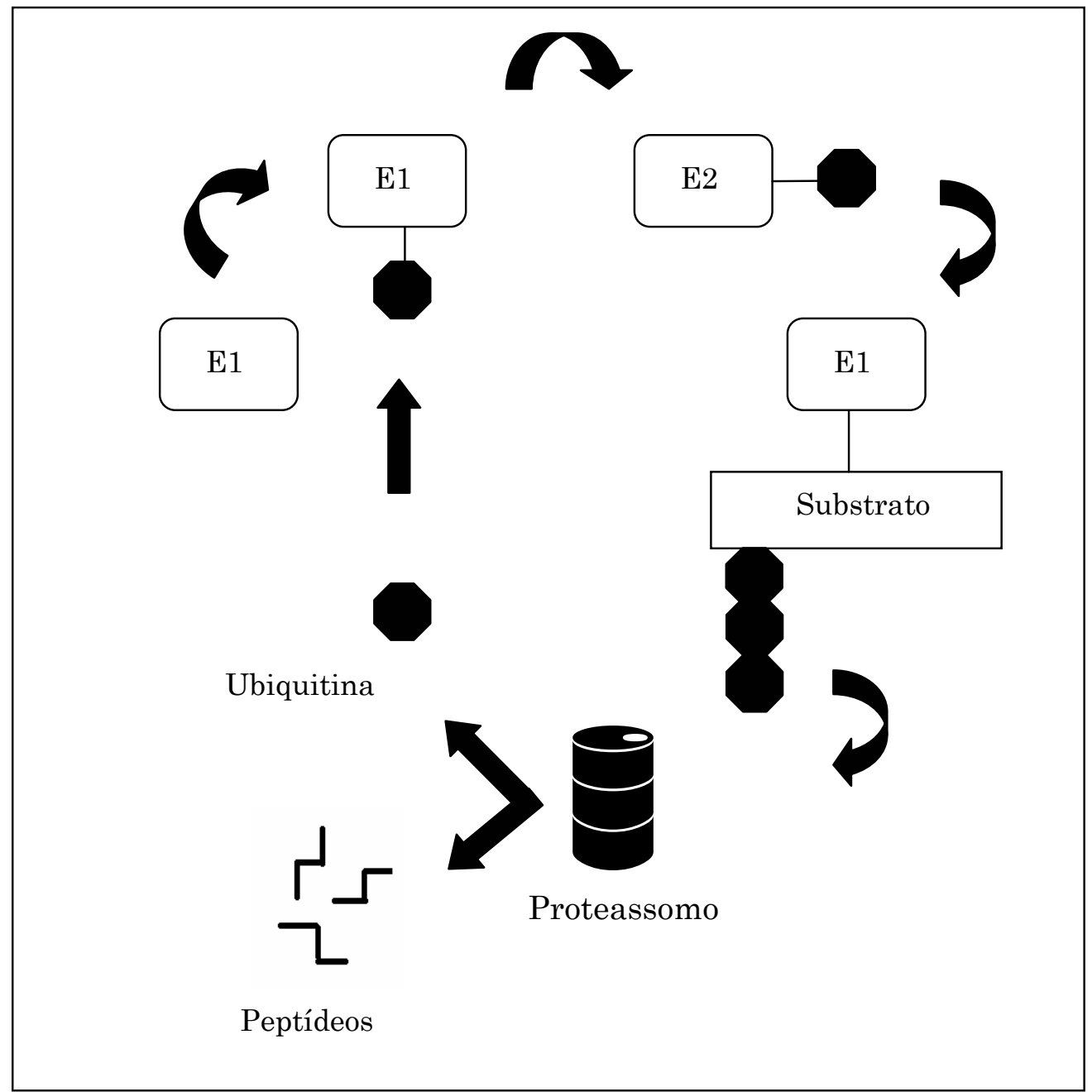

Figura 1. Representação esquemática do sistema ubiqutina-proteassomo de processamento de proteínas.

A maioria das mutações no gene de parkin parece ocasionar alterações do tipo "perda de função" ${ }^{45}$ : na presença do defeito de parkin, a ubiquitinação e conseqüente remoção de substratos ficam comprometidas, resultando em seu acúmulo e subseqüente toxicidade. Estudos sugeriram também um papel potencial da parkin no estresse oxidativo e disfunção mitocondrial ${ }^{31}$. 
O quadro clínico característico de PARK2 difere da DP clássica por estar associado a distonia, tipicamente no início da doença, e apresentar características como hiperreflexia, progressão mais lenta e complicações precoces do tratamento com levodopa (maior susceptibilidade a discinesias e flutuações motoras) ${ }^{33}$. Patologicamente a perda celular é restrita à parte compacta da substância negra e locus ceruleus e tipicamente não são observados corpos de Lewy. Os pacientes portadores destas mutações carreiam deleções ou mutações pontuais em várias partes do gene parkin ${ }^{43}$.

*PARK5 - UCH-L1

Outra mutação familiar rara de DP afeta a ubiquitina carboxil-terminal hidrolase-1 (UCH-L1), um componente do sistema ubiquitina-proteassomo da célula, que degrada proteínas lesadas. Entre as funções já registradas de UCH-L1 destaca-se a atividade hidrolase, através da qual ocorre reciclagem das cadeias de ubiquitina de polímeros para monômeros após a degradação pelo proteassomo, de forma que possam interagir com outras proteínas. Além disso, a proteína apresenta atividade ubiquitina ligase, "ubiquitinando" a alfa-sinucleína, isto é, assinalando-a para posterior degradação ${ }^{47}$.

A descoberta deste gene reforçou a relevância do sistema ubiquitinaproteassomo na patogênese da DP. UCH-L1 é uma enzima encontrada em todo o cérebro, para a qual já foi demonstrada imunorreatividade nos corpos de Lewy ${ }^{2}$. A mutação foi identificada inicialmente em dois irmãos de uma família alemã, com DP típica e padrão autossômico dominante de herança. A forma mutante de UCH-L1 
exibe atividade enzimática reduzida, resultando em alteração na remoção de proteínas indesejadas pelo sistema ubiquitina-proteassomo ${ }^{43}$.

\section{*PARK6 - PINK1}

PARK6 foi descrito em três grandes famílias da Sicília, Itália e Espanha. O curso clínico é semelhante ao da DP idiopática clássica, com discinesias precoces, mas boa resposta a levodopa ${ }^{33}$. O gene correspondente a PARK6 é o PINK1 (PTENinduced putative kinase 1), que codifica uma quinase mitocondrial ${ }^{43}$ e está localizado no braço curto do cromossomo $1^{23}$. Este gene parece proteger os neurônios de disfunção mitocondrial e apoptose induzidas por estresse; este efeito estaria suprimido no caso de mutação ${ }^{48}$. Mutações de PINK1 são a segunda causa mais comum de DP de início precoce ${ }^{35}$. Especula-se que PINK1 exerça seu papel protetor através da fosforilação de certas subunidades enzimáticas da cadeia respiratória ${ }^{43}$.

*PARK7 - DJ1

A descoberta de PARK7, localizado no gene DJ-1, ocorreu em 2003 por Bonifati et $\mathrm{al}^{49}$. Foi inicialmente identificado em duas famílias consangüíneas com DP de início precoce e herança autossômica recessiva em populações isoladas da Holanda e da Sicília ${ }^{50}$. O gene DJ-1 codifica uma proteína altamente conservada, cuja função permanece desconhecida, mas as evidências sugerem seu envolvimento na resposta ao estresse oxidativo ${ }^{49}$. A redução da expressão de DJ-1 resulta em inibição do proteassomo e susceptibilidade ao estresse oxidativo, levando a uma sensibilidade seletiva a toxinas ambientais, como rotenona ${ }^{13}$, um agente que 
sabidamente pode ocasionar um quadro de parkinsonismo. A DJ-1 parece estar envolvida também na regulação da transcrição ${ }^{50}$.

O fenótipo clínico de DJ-1 é semelhante ao de parkin, com idade de início precoce, boa resposta à levodopa e progressão relativamente lenta. A patologia ainda é desconhecida ${ }^{31,33}$. Blefaroespasmo e distonia de membro inferior, assim como distúrbios psiquiátricos precoces, já foram descritos nos pacientes com esta mutação $0^{50}$.

PARK7 parece ser uma causa rara de DP, determinando principalmente doença de início precoce (antes de 40 anos), com prevalência neste grupo de cerca de 1 a $2 \%$ dos $\operatorname{casos}^{35}$.

*PARK8 - LRRK2

A mutação correspondente a PARK8 foi identificada no gene LRRK2 (leucinerich repeat kinase 2) em 2004 por dois grupos independentes de pesquisadores que observaram que o gene estava ligado ao cromossomo $12^{51}$. PARK8 parece explicar 0,5 a 2\% dos casos de DP esporádica e $5 \%$ dos casos de parkinsonismo familiar, representando a causa genética mais comum de casos familiares e esporádicos de $\mathrm{DP}^{52}$. A mutação G2019S é a mais comum e tem penetrância variável ${ }^{43}$.

Postula-se que LRRK2 seja membro da família de proteínas quinases ${ }^{13}$, que são responsáveis pela regulação da maioria das vias celulares, especialmente aquelas relacionadas à transdução de sinal. As mutações no gene aumentam sua atividade quinase. LRRK2 reside na membrana mitocondrial externa, de forma semelhante a parkin $^{52}$. Devido ao tremor observado na DP e porque uma parte das famílias com 
PARK8 eram de ascendência basca, a proteína codificada pelo gene LRRK2 foi denominada dardarina, derivada da palavra basca “dardara", que significa tremor ${ }^{53,54}$.

LRRK2 parece ser central na etiologia de várias doenças neurodegenerativas, incluindo sinucleinopatias e taupatias. Potencialmente, LRRK2 pode ser responsável pela fosforilação tanto da alfa-sinucleína como da proteína tau; sua atividade quinase pode ser um evento chave no acúmulo e agregação destas proteínas nos neurônios em degeneração ${ }^{41}$. Acredita-se que LRRK2 tenha um papel também na integração do tráfego celular e sinalização intracelular ${ }^{13}$, além de respostas do citoesqueleto a estímulos externos.

A mutação de PARK8 pode resultar em uma doença de início tardio, dificultando o reconhecimento de formas familiares, já que os carreadores da mutação podem morrer antes de manifestar sinais e sintomas de DP ou antes de serem devidamente diagnosticados. Em geral, os pacientes têm características típicas de DP, com início assimétrico de tremor, bradicinesia e rigidez ${ }^{43}$. A idade média de início é em torno de 65 anos e o curso é benigno, com resposta excelente a doses baixas de levodopa.

\subsection{Fisiopatologia da DP: visão atual}

Apesar de ainda não se ter pleno conhecimento dos processos que ocasionam o desenvolvimento de DP, muito se avançou neste sentido nos últimos anos. A partir das descobertas genéticas, estudos epidemiológicos, investigações neuropatológicas e de modelos experimentais mais fidedignos, atualmente acredita-se que a DP decorra de alterações mitocondriais, na via de processamento de proteínas pelo sistema ubiquitina-proteassomo (a agregação de proteínas é uma característica patológica 
consistente de doenças neurodegenerativas e seu dobramento é fundamental para a função normal das mesmas $^{55}$ ) e de estresse oxidativo ${ }^{48}$, que culminam com a agregação e depósito de alfa-sinucleína nos corpos de Lewy. Spillantini et al. descreveram em 1997 que os corpos de Lewy se coravam fortemente com anticorpos para alfa-sinucleína, concluindo que a mesma devia ser o principal componente dos corpos de Lewy na $\mathrm{DP}^{38}$. $\mathrm{O}$ valor desta descoberta foi fornecer uma base para o desenvolvimento de um programa para identificar novas drogas que possam modificar o curso da DP.

A hipótese fisiopatológica vigente para explicar a DP baseia-se no papel atribuído às proteínas que foram ligadas a parkinsonismo por estudos genéticos até o momento: dinâmica de lipídeos e vesículas (alfa-sinucleína), sistema ubiquitinaproteassomo (parkin e UCH-L1), sinalização de quinases (dardarina) e estresse oxidativo e função mitocondrial (DJ1, PINK1). Evidentemente estas funções diversas devem se sobrepor, já que todas elas convergem para a morte de neurônios dopaminérgicos, que caracteriza a DP. LRRK2 e PINK1 codificam proteínas quinases, que por sua vez podem integrar uma cascata de mensageiro secundário que influencia a fosforilação de proteínas que se acumulam no estágio final da doença ${ }^{13}$. Tanto mutações no gene de parkin, através da perda de função, como de DJ1, que pode funcionar como uma chaperona (isto é, uma proteína cuja função é auxiliar outras proteínas a assumirem a conformação apropriada), possivelmente comprometem a capacidade da célula de lidar com a disfunção do proteassomo ${ }^{56}$.

O papel da alfa-sinucleína na DP foi reforçado pela descoberta de mutações no seu gene como causa de DP hereditário autossômico dominante ${ }^{56}$. Tanto nas formas esporádica como familiar da DP, a alfa-sinucleína é o principal componente 
estrutural dos corpos de Lewy e neuritos de Lewy ${ }^{42}$. Os neuritos de Lewy correspondem a neuritos anormais que contêm filamentos semelhantes àqueles encontrados nos corpos de Lewy ${ }^{38}$. Conforme mencionado anteriormente, o marcador patológico da DP são os corpos de Lewy, que consistem em inclusões citoplasmáticas eosinofílicas arredondadas compostas de um centro menos definido de alfa-sinucleína (principal componente) agregada e outras proteínas, rodeado por fibrilas radiadas ${ }^{57}$, encontradas em todas as regiões cerebrais afetadas pela doença ${ }^{7}$. Ainda que estejam notadamente ausentes na maioria dos casos de PARK2 (tendo sido sugerido então que a função de parkin possa ser promover a formação de inclusões nos corpos de $\operatorname{Lewy}{ }^{56}$ ), parecem representar o ponto final comum de diferentes vias que levam à degeneração dos neurônios dopaminérgicos. Nos estágios precoces da doença, os corpos de Lewy inicialmente se desenvolvem no bulbo e tronco cerebral inferior; nos estágios intermediários são encontrados no prosencéfalo basal e nos casos mais avançados podem aparecer no neocórtex ${ }^{57,58}$. Os mecanismos implicados até o momento na fisiopatologia da DP envolvem diferentes processos celulares, mas as evidências sugerem que ocorra uma interação entre eles, desencadeando uma síndrome neurológica comum.

Uma questão fundamental para a patogênese da DP parece envolver uma falha na conformação de proteínas e uma deficiência na correção destas proteínas aberrantes. Existem duas vias de degradação protéica nas células: as chaperonas e o sistema ubiquitina-proteassomo ${ }^{56}$. Ambas são responsáveis pela identificação, seqüestro e eliminação de proteínas cujo dobramento (que define sua conformação) seja inadequado. As chaperonas se ligam a tais proteínas, que são conseqüentemente degradadas por lisossomos, organelas celulares que contêm enzimas para digestão de 
macromoléculas, e proteassomo. Já o sistema ubiquitina-proteassomo representa a principal rota não-lisossomal de degradação destas proteínas lesadas. Nessa via (Figura 1), o processo se inicia com a ubiquitinação, através da enzima ativadora de ubiquitina E1, que transfere a ubiquitina ativada para a enzima conjugadora de proteína E2, que, por sua vez, com o auxílio da enzima ligadora de ubiquitina E3, transfere a ubiquitina ativada, tornando as proteínas mal dobradas alvos para degradação posterior ${ }^{59}$. As proteínas marcadas pela ubiquitina sofrem degradação proteolítica através do complexo enzimático chamado proteassomo.

Construindo um paralelo com as descobertas genéticas, sabe-se que parkin é uma ubiquitina E3 ligase e que UCH-L1 recicla as moléculas usadas de ubiquitina, portanto mutações nestes genes interferem no funcionamento normal do processo descrito, levando a um acúmulo de proteínas indesejadas.

Acredita-se que na DP, devido a uma disfunção do sistema ubiquitinaproteassomo, hipótese favorecida pela descoberta das mutações PARK2 e PARK5, ocorra uma remoção inadequada da alfa-sinucleína, conseqüentemente observandose sua presença nos corpos de Lewy. O acúmulo de alfa-sinucleína anormal (sob a forma de oligômeros e protofibrilas), decorrente de uma falha de ubiquitinação, por sua vez inibe o proteassomo em sua função ubiquitina-dependente através de ação $\operatorname{direta}^{56}$.

A mutação no gene da alfa-sinucleína (PARK1) está associada a um ganho tóxico de função ${ }^{57}$ e aumenta a propensão da proteína a se polimerizar anormalmente em filamentos, formando protofibrilas, que então se agregam e se depositam nos corpos de Lewy. O neurônio pode reagir ao aumento do acúmulo citoplasmático do monômero alfa-sinucleína degradando-a rapidamente através do sistema ubiquitina- 
proteassomo e/ou vias endossomais/lisossomais ou direcionando a formação e agregação de fibrilas de maior peso molecular. Os neurônios dopaminérgicos são seletivamente vulneráveis à toxicidade pela alfa-sinucleína ${ }^{31}$. Ainda se discute se o seqüestro das protofibrilas nos agregados seria uma forma de a célula se defender da sua toxicidade ${ }^{13,59}$, porém algumas evidências sugerem o contrário, isto é, que os corpos de Lewy seriam tóxicos por si só. Por exemplo, há uma correlação entre a quantidade de corpos de Lewy e a gravidade da doença. Além disso, os agregados de alfa-sinucleína podem preencher grande parte do citoplasma das células afetadas, dificultando o trânsito celular ${ }^{57}$. Outros autores, como McNaught ${ }^{46}$, defendem que a formação dos corpos de Lewy seria uma resposta protetora, mais do que simplesmente um epifenômeno. Acredita-se que a alfa-sinucleína possa ter um papel na plasticidade sináptica e na modulação da neurotransmissão dopaminérgica ${ }^{42}$. A alfa-sinucleína sob a forma de protofibrilas poderia permeabilizar membranas celulares através da formação de poros, alterando o ambiente intracelular e predispondo estas células à apoptose. A permeabilização das vesículas sinápticas permitiria que a dopamina vazasse no citoplasma e então participasse de reações que geram estresse oxidativo ${ }^{7}$, outro processo associado ao desenvolvimento de DP. Como se atribui à alfa-sinucleína função de regulação da formação de vesículas sinápticas, mutações na alfa-sinucleína também podem resultar em menor número de vesículas disponíveis para o armazenamento de dopamina, levando a um acúmulo de dopamina no citoplasma e subseqüente aumento dos níveis de estresse oxidativo ${ }^{59}$.

A alfa-sinucleína interage com ácidos graxos poliinsaturados in vivo para promover a formação de oligômeros altamente solúveis que precedem os agregados insolúveis de alfa-sinucleína associados à neurodegeneração ${ }^{60}$. O equilíbrio entre a 
alfa-sinucleína associada a lipídeos e a proteína no citoplasma parece fornecer uma ligação entre os mecanismos de produção de dopamina e empacotamento e dinâmica de vesículas. A alteração na liberação de neurotransmissores e seu acúmulo no citossol podem levar à formação de espécies reativas de oxigênio ${ }^{13}$.

O estresse oxidativo é uma condição deletéria que resulta da supressão insuficiente de espécies reativas de oxigênio, que são geradas por uma série de reações bioquímicas. Normalmente estas espécies são eliminadas por sistemas antioxidantes intracelulares, que podem ser alterados em algumas doenças ${ }^{59}$. A participação do estresse oxidativo na patogênese da DP, assim como da disfunção mitocondrial, é sugerida por: localização de PINK1 (PARK6) e DJ1 (PARK7) na mitocôndria, desenvolvimento de parkinsonismo por inibidores do complexo I da cadeia transportadora de elétrons mitocondrial (como rotenona e MPTP) e o achado consistente em estudos pós-mortem de pacientes com DP de deficiência do complexo $\mathrm{I}^{10,31}$. Quando a atividade do complexo I mitocondrial encontra-se deficiente, a formação de ATP é reduzida, levando à despolarização da membrana ${ }^{56}$. Este processo favorece a formação de espécies reativas de oxigênio e torna os neurônios mais suscetíveis à excitoxicidade pelo glutamato ${ }^{30}$.

O próprio metabolismo da dopamina pode levar à formação de espécies reativas de oxigênio, expondo particularmente os neurônios dopaminérgicos nigrais $^{59}$, e o estresse oxidativo resultante pode, além de exercer efeitos sobre a integridade celular, promover o dobramento inadequado de proteínas e exacerbar a agregação de alfa-sinucleína no citoplasma. A inibição do complexo I também pode afetar o sistema ubiqutina-proteassomo, aparentemente por gerar espécies reativas de oxigênio que causam dano oxidativo a proteínas, talvez incluindo componentes do 
proteassomo $^{47}$. O estresse oxidativo também potencializa a agregação e a toxicidade da alfa-sinucleína ${ }^{10}$, especialmente na presença de dopamina ${ }^{57}$.

Em resumo, os inibidores de proteassomo lesam a mitocôndria e as toxinas mitocondriais levam à lesão do proteassomo, diretamente ou reduzindo o ATP necessário para a função normal do sistema ubiquitina-proteassomo. Tanto disfunção mitocondrial como do sistema ubiquitina-proteassomo podem levar a ou ser causados por estresse oxidativo ${ }^{43}$. (Figura 2)

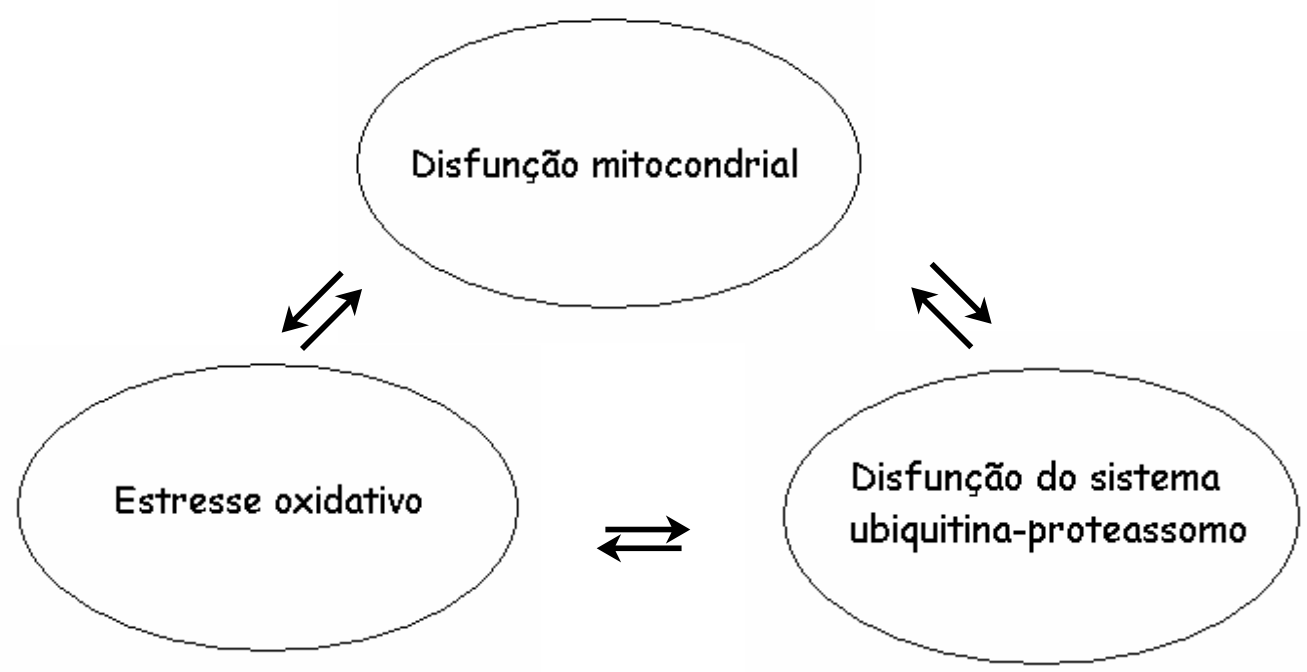

Figura 2. Inter-relação entre os processos celulares associados à patogênese da DP.

\subsection{Doença de Gaucher}

Antes de passar à discussão do projeto de pesquisa, que descreve a associação da DP com mutações próprias da doença de Gaucher (DG), é válido mencionar de forma resumida do que se trata a DG. A associação, entre doenças aparentemente tão díspares, fornece um exemplo de heterozigose para uma doença mendeliana agindo como fator de risco para uma doença complexa ${ }^{61}$. 


\section{6.a.Histórico, definição e genética}

Em 1882, Phillipe Charles Ernest Gaucher, um médico francês, descreveu uma nova doença em uma paciente de 32 anos com hepatoesplenomegalia, no que veio a ser sua tese de doutorado. Esta condição foi chamada por Brill de doença de Gaucher em 1905. A ocorrência familiar da doença já havia sido reconhecida em 1901, porém o padrão de herança foi esclarecido somente vários anos depois ${ }^{62}$.

Em 1934, Aghion relatou que pacientes com a doença apresentavam acúmulo de um esfingoglicolipídeo denominado glicocerebrosídeo. Em 1964, Brady demonstrou que este acúmulo resultava da deficiência de uma enzima - a glicocerebrosidase ${ }^{63}$.

A DG é o mais comum dos distúrbios hereditários de depósito lisossomal, com uma prevalência estimada de 1:57.000 nascidos vivos na população geral ${ }^{64}$. Os lisossomos são vesículas intracitoplasmáticas que contêm uma variedade de enzimas de degradação que catabolisam substratos complexos, como esfingolipídeos, gangliosídeos, cerebrosídeos, sulfatídeos, mucopolissacarídeos e glicoproteínas ${ }^{65}$.

A DG é determinada geneticamente por várias mutações no gene da enzima $\beta$ glicosidase (glicocerebrosidase), localizado no cromossomo $1^{66}$. Como resultado da mutação, ocorre redução da atividade da enzima, que é responsável pela catalisação da clivagem hidrolítica da glicose a partir do glicocerebrosídeo, com conseqüente acúmulo do glicolipídeo glicocerebrosídeo nas células do sistema monocitário ${ }^{67}$ (Figura 3). Esse processo pode levar a hepatoesplenomegalia, doença óssea, envolvimento pulmonar e pancitopenia ${ }^{68}$. O limiar crítico abaixo do qual a atividade enzimática baixa leva ao acúmulo de glicocerebrosídeos é estimado em 11 a $15 \%{ }^{69}$. 
O gene da DG foi mapeado no cromossomo 1q21 e até o momento mais de 200 alelos mutantes já foram identificados ${ }^{70}$. As mutações mais freqüentes são [c.1226A >G;N370S] e [c.1448T>C;L444P], aqui denominadas N370S e L444P, respectivamente. A análise da mutação tem valor preditivo considerável no que diz respeito ao prognóstico, apesar de não ser absoluto. A mutação L444P deriva da seqüência do pseudogene, adjacente ao gene da GBA, que compartilha 96\% de homologia da sequiência e dificulta as estratégias de detecção de mutação ${ }^{71}$.

Foram descritos três fenótipos principais na DG, detalhados a seguir. Heterogeneidade foi observada em todos os três fenótipos, particularmente no tipo 1. A mutação mais comum no tipo $1, \mathrm{~N} 370 \mathrm{~S}$, leva a um menor envolvimento do sistema nervoso central, mesmo na forma heterozigótica ${ }^{64}$. A mutação grave L444P é a mais freqüente na população não-Ashkenazi de $\mathrm{DG}^{72}$ (judeus Ashkenazi são aqueles descendentes de comunidades judaicas da Alemanha, Polônia, Áustria e Leste Europeu e representam cerca de $80 \%$ do total da população judaica mundial atualmente). A classificação dos pacientes pela identificação de mutações específicas é a mais promissora: homozigose para N370S invariavelmente prediz o tipo 1, enquanto homozigose para L444P geralmente indica o tipo 3 da doença ${ }^{73}$.

Os heterozigotos são sempre assintomáticos para DG. Na ausência da enzima, seus substratos, glicocerebrosídeo e glicosilesfingosina, derivados da fagocitose de hemácias e leucócitos senescentes ${ }^{74}$, se acumulam no sistema retículo-endotelial.

\section{6.b.Classificação}

A DG é classicamente dividida em três subtipos, de acordo com a presença ou não de quadro neurológico e a progressão dos sinais clínicos em 
desenvolvimento $^{75}$ (Tabela 2). Já foi descrito, entretanto, um fenótipo intermediário entre os tipos 2 e $3^{76}$, sugerindo que a DG compreende um continuum de fenótipos, muitos dos quais não podem ser definidos dentro da classificação nos três tipos clássicos. A classificação de pacientes com DG em subtipos é importante para avaliação de prognóstico e resposta ao tratamento ${ }^{72}$.

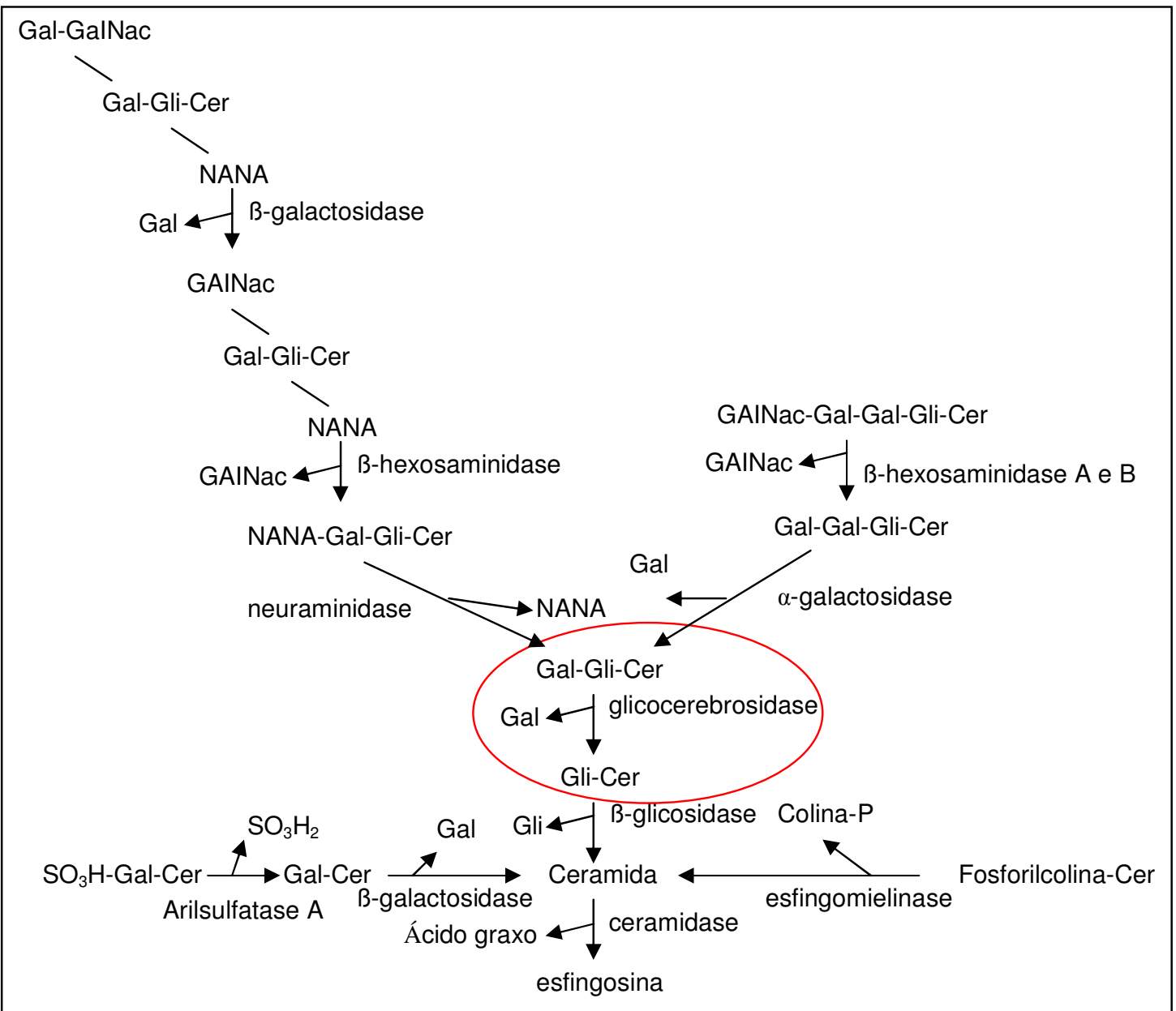

Figura 3. Via do metabolismo lipídico, ressaltando a etapa da enzima deficiente na DG. Cer:ceramida; Gli:glicose; Gal:galactose; GAINac:Nacetilgalactosamina; NANA:ácido N-acetilneuramínico. 
Os três grupos clínicos de DG têm transmissão autossômica recessiva e apresentam como características comuns: hepatoesplenomegalia, hiperesplenismo, células de Gaucher na medula óssea e níveis reduzidos de glicocerebrosidase nos órgãos e tecidos ${ }^{62}$. Recebem a denominação de "células de Gaucher" macrófagos com aparência característica devido ao acúmulo de glicocerebrosídeos nos lisossomos, com deslocamento do núcleo e citoplasma, com aspecto de "papel amassado"61. Trombocitopenia é a alteração de sangue periférico mais freqüentemente observada. Esplenomegalia está presente em quase todos os pacientes, podendo o baço atingir dimensões significativas. $\mathrm{O}$ envolvimento da medula óssea resulta do acúmulo de células de Gaucher, comprometimento vascular, infarto e cicatrização. Como consequiência deste comprometimento, a alteração mais freqüente é a redução da massa óssea ou osteoporose. Envolvimento cardíaco ou pulmonar é raro, mas quando presente, indica mau prognóstico ${ }^{62}$. Geralmente a doença óssea é responsável pela maior morbidade e limitação funcional a longo prazo $^{77}$. Os aspectos neurológicos da DG, presentes nos tipos 2 e 3 da doença, englobam um amplo espectro de manifestações clínicas (epilepsia, retardo mental, sinais piramidais, etc.) e se originam de disfunção neuronal, mais provavelmente causada por acúmulo de glicocerebrosídeos em neurônios ${ }^{78}$.

A DG tipo 1 é a mais comum, com distribuição pan-étnica, porém com predileção por judeus Ashkenazi, nos quais a taxa de carreador chega a 1:17 $7^{78}$. Aproximadamente $95 \%$ dos pacientes com DG são classificados como tipo $1^{62}$. Já os tipos 2 (infantil, neuronopática aguda) e 3 (juvenil, neuronopática subaguda) são raros e pan-étnicos ${ }^{79}$. Existe registro de incidência maior da DG tipo 3 na Suécia, em Norrbotten ${ }^{80}$. 
A DG tipo 1 (do adulto) tem um curso clínico cronicamente progressivo e até recentemente era considerada não-neuronopática. O quadro clínico caracteriza-se pelo envolvimento essencialmente de órgãos periféricos. O início da doença pode ocorrer em qualquer idade, tanto em crianças como em indivíduos mais velhos. O curso é variável, com acelerações súbitas em qualquer faixa etária. A apresentação no tipo 1 é inconstante: mesmo entre membros de uma família com o mesmo genótipo, a gravidade da doença pode variar.

\begin{tabular}{|l|l|l|l|}
\hline Características clínicas & Tipo 1 & Tipo 2 & Tipo 3 \\
\hline Idade de início & Infância/Vida adulta & $<6$ meses & Infância \\
\hline Esplenomegalia & Presente & Presente & Presente \\
\hline Hepatomegalia & Presente & Presente & Presente \\
\hline Doença esquelética & Ausente ou presente & Ausente & Presente \\
\hline $\begin{array}{l}\text { Doença primária do } \\
\text { sistema nervoso central }\end{array}$ & Ausente & Presente & $\begin{array}{l}\text { Presente } \\
\left(1^{\mathrm{a}} \text { a } 5^{\mathrm{a}} \text { décadas) }\right.\end{array}$ \\
\hline Sobrevida & 6 a 80 ou+ anos & $\sim 2$ anos & 2 a 60 anos \\
\hline Etnia/Grupo demográfico & $\begin{array}{l}\text { Pan-étnico } \\
\text { Judeus Ashkenazi }\end{array}$ & Pan-étnico & $\begin{array}{l}\text { Pan-étnico } \\
\text { Norrbotten (Suécia) }\end{array}$ \\
\hline
\end{tabular}

Tabela 2 - Formas clínicas da doença de Gaucher

Quase todos os pacientes afetados pela DG apresentam lesões ósseas ao longo da evolução da doença. Pode ocorrer alargamento ósseo associado a afilamento da cortical, abaulando o contorno ósseo e gerando uma imagem radiográfica clássica no fêmur distal, denominada deformidade de Erlenmeyer ${ }^{81}$. Crises de dor óssea ocorrem em até 20 a $40 \%$ dos pacientes $^{62}$. A presença da mutação mais comum, N370S, em 
um alelo parece ser protetora para o desenvolvimento de formas neuronopáticas da DG e, de fato, o genótipo N370S/N370S é o mais comum entre pacientes com o tipo 1 da doença. Somente pacientes pertencentes à categoria do tipo 1 sobrevivem além da terceira década de vida.

A DG tipo 2, uma forma neuronopática aguda rara, é uma doença neurológica rapidamente fatal. Inicia-se geralmente antes de 6 meses de idade e costuma levar ao óbito ao redor dos 2 anos. Caracteriza-se por um abdome protuberante, hepatoesplenomegalia e início das manifestações neurológicas por volta de 6 meses de idade e mais raramente pouco após o nascimento. O quadro neurológico, exuberante, envolve regressão do desenvolvimento psicomotor, hipertonia, estrabismo, estridor e hiperextensão da cabeça, que contribui para a morte (por pneumonia aspirativa, na maioria dos casos) antes de 2 anos de idade ${ }^{79,82}$. Trismo, paralisia ocular, disfagia, estridor laríngeo, hiperreflexia, resposta plantar em extensão, convulsões e perda sensitiva são manifestações menos comuns. A sobrevida média é em torno de 9 meses ${ }^{83}$.

A DG tipo 3 (juvenil) consiste em uma forma neuronopática crônica; é uma doença neurológica progressiva de início mais tardio que o tipo 2, levando ao óbito geralmente na segunda ou terceira décadas de vida. Nestes casos, o envolvimento neurológico caracteriza-se pelo início, na primeira ou segunda décadas de vida, de deterioração mental, convulsões, distúrbios de comportamento, tremor, alteração da coordenação, paralisia dos movimentos extraoculares e hipertonia ${ }^{83}$. A principal manifestação no sistema nervoso central na DG tipo 3 é a paresia do olhar horizontal. Pode haver também paralisia do olhar vertical e epilepsia mioclônica ${ }^{63}$. 


\section{6.c.Diagnóstico}

A DG caracteriza-se pela presença em vários tecidos das células de Gaucher, que são preenchidas por lipídeos e apresentam aparência típica. Além das células de Gaucher, as alterações histológicas mais precoces observadas são a presença de fibras reticulares, levando à fibrose nas vísceras acometidas.

Leucócitos do sangue periférico normalmente apresentam intensa atividade da glicocerebrosidase, porém na DG sua capacidade de clivar glicosilceramida está significativamente reduzida. O paciente típico com DG tipo 1 apresenta atividade enzimática de 10 a $30 \%$ do normal ${ }^{77}$. Todos os pacientes vivos com DG exibem alguma atividade residual da enzima ${ }^{84}$. A demonstração da deficiência enzimática permanece como padrão-ouro para estabelecer o diagnóstico de $\mathrm{DG}^{85}$. No entanto, não é possível prever o curso clínico da doença a partir da medida da atividade residual da glicocerebrosidase ${ }^{73}$.

A tecnologia baseada na identificação de mutações no gene da glicocerebrosidase tem vantagens sobre o diagnóstico enzimático, já que os resultados são qualitativos. Ela fornece um guia útil para a classificação fenotípica precocemente no curso da doença ${ }^{67}$. A mutação N370S é responsável por 80 a $90 \%$ dos alelos produtores da doença em judeus Ashkenazi. Entre não-judeus, as mutações L444P e N370S representam 70\% dos alelos mutantes. Pacientes homozigotos para L444P parecem ter doença visceral grave e geralmente desenvolvem doença neurológica.

Tradicionalmente, a fonte de DNA para análise do gene era a coleta de sangue e posterior exame de leucócitos fracionados, mas este método apresenta algumas desvantagens, como desconforto para o paciente, risco de exposição a patógenos, 
custo e necessidade de manipulação de líquidos. Como alternativa, progressivamente mais utilizada em estudos genéticos, existe a opção de coleta de DNA da mucosa da boca - método escolhido neste estudo, como será comentado adiante. O DNA desta fonte tem boa relação custo-benefício em estudos de larga escala e fornece quantidade e qualidade suficientes de DNA para genotipagem. Além disso, é simples, as células obtidas são estáveis e permite reprodutibilidade da amplificação através de PCR, tornando o método confiável ${ }^{86}$.

Ao se estudarem as mutações da GBA, é necessário o cuidado adicional de discriminar mutações provenientes de recombinação entre o gene da glicocerebrosidase e seu pseudogene.

O pseudogene da GBA é uma duplicata não funcional do gene responsável pela DG (GBA), com o qual tem alta homologia e pode se combinar, formando alelos complexos. As variantes do pseudogene da GBA podem ser confundidas com mutações da $\mathrm{GBA}^{87}$. Os chamados rearranjos complexos na DG incluem os produtos gênicos resultantes da combinação das seqüências de DNA da GBA e seu pseudogene: esses alelos são chamados alelos complexos, pseudopadrão, "rec" (de "recombinante") ou alelos de fusão. Podem surgir por crossover recíproco, em que o gene de um alelo se alinha com a sequiência do pseudogene no outro alelo, freqüentemente em regiões com alta homologia; originando um alelo de fusão; crossover intramolecular entre o gene e o pseudogene no mesmo cromossomo e através de conversão genética, uma mudança de sequiência não-recíproca entre seqüências alélicas ou não. Dessa forma, recomenda-se que o DNA de todos os pacientes carreadores de uma mutação pontual derivada de pseudogene seja examinado para a presença de um alelo recombinante da GBA ${ }^{61}$. As recombinações 
do gene da glicocerebrosidase com o pseudogene podem complicar a genotipagem de pacientes com DG e contribuir para a dificuldade na interpretação das correlações genótipo-fenótipo nesta doença ${ }^{88}$

Vários alelos com mutações múltiplas foram identificados como sendo derivados de rearranjos entre o gene estrutural e o pseudogene da GBA ${ }^{72}$. E326K é um modificador de fenótipo associado a L444P em vários pacientes com DG. A mutação E326K já foi identificada em pacientes com DG dos tipos 1,2 e 3. No entanto, em todos os casos, foi encontrada no mesmo alelo em que outra mutação da glicocerebrosidase, sugerindo que esta mutação deve ser considerada uma variante modificadora, que pode ser não patogênica ou ser levemente patogênica por si só, mas que tem um efeito aditivo sobre outra mutação, tornando-a patogênica e diminuindo ainda mais a atividade enzimática ${ }^{89,90}$.

V460V, por sua vez, faz parte de um grupo de mutações resultantes da recombinação homóloga entre o gene e o pseudogene da glicocerebrosidase. O efeito fenotípico do alelo L444P + V460V é provavelmente idêntico àquele com a mutação L444P isolada, uma vez que V460V não muda a seqüência de aminoácidos.

Além das técnicas específicas mencionadas, os seguintes exames complementares podem auxiliar no diagnóstico da DG, mostrando alterações sugestivas da mesma: hemograma, ultra-sonografia de abdome, radiografia de tórax e de ossos e densitometria óssea.

\section{6.d.Tratamento}

A DG é um paradigma para a intervenção terapêutica na genética médica ${ }^{74}$ devido à existência de uma terapia de reposição enzimática eficaz ${ }^{91}$. Esse tratamento 
faz com que a DG tenha uma importância econômica significativa, apesar de sua baixa incidência. A terapia de reposição enzimática para a DG foi aprovada pelo FDA (Food and Drug Administration) em $1991^{67}$.

O tratamento da DG classicamente incluía hidratação e analgesia para crises de dor óssea; esplenectomia (eficaz para a trombocitopenia e anemia e também indicada na esplenomegalia acentuada), procedimentos ortopédicos, como $\operatorname{artroplastia~}^{92}$ e transplante de medula óssea (indicado em casos específicos e limitado pelas complicações próprias do procedimento), porém atualmente o tratamento de escolha é a terapia de reposição enzimática.

A deficiência de glicocerebrosidase foi identificada como a causa da DG em 1965. Christian de Duve descobriu os lisossomos - organelas subcelulares - e foi o primeiro a sugerir que a terapia de reposição enzimática poderia ser útil nestas doenças $^{91}$.

A terapia de reposição enzimática é de alto custo - 40 a 320 mil dólares por ano $^{91}$ - mas extremamente eficaz para as manifestações sistêmicas dos pacientes com DG, não conseguindo, no entanto, reverter os déficits neurológicos nos tipos 2 e 3 da doença $^{74}$. Utiliza enzima derivada da placenta (alglucerase - a glicocerebrosidase está presente no tecido placentário e foi inicialmente purificada a partir desta fonte ${ }^{84}$ ) ou produto recombinante (imiglucerase), que apresentam eficácia clínica e efeitos adversos semelhantes, em infusões intravenosas periódicas, com uma dose média de 60U/kg a cada 2 semanas $^{85}$. Deve ser empregada de forma contínua.

A regressão da organomegalia geralmente ocorre dentro dos primeiros 6 meses de tratamento, enquanto a regressão das alterações ósseas se dá de forma muito mais lenta ${ }^{85}$. A terapia de reposição enzimática impede a progressão das manifestações da 
DG e melhora a anemia, trombocitopenia, organomegalia e dor óssea associadas à doença $^{93}$.

Atualmente mais de 4300 pacientes no mundo todo recebem terapia de reposição enzimática para $\mathrm{DG}^{84}$.

Na DG tipo 3, a terapia de reposição enzimática é muito eficaz em relação ao controle das manifestações sistêmicas da doença, mas a melhora do movimento ocular e da epilepsia não foi descrita de forma convincente. Esta deficiência do tratamento estimulou a pesquisa de reposição enzimática com uma glicocerebrosidase recombinante com alvo no macrófago, associada à administração oral de uma substância (miglustat), que bloqueia a enzima glicosilceramida sintase, responsável pela primeira etapa da biossíntese da maioria dos glicoesfingolipídeos. Essa abordagem é chamada de terapia de redução de substrato e espera-se que seja capaz de atravessar a barreira hemato-encefálica para inibir a biossíntese de quantidades tóxicas de glicocerebrosídeo no sistema nervoso central e proporcionar benefício clínico ${ }^{84}$. Ela é um meio de reduzir o acúmulo de glicocerebrosídeo através da limitação da quantidade de precursor sintetizado para um nível que possa ser removido pela enzima afetada com a sua atividade hidrolítica residual.

\subsection{Associação entre DP e DG}

Apesar de a DG tipo 1 ser classicamente definida como não-neuronopática, relatos de literatura datados até de 1942 descreviam casos isolados de pacientes que desenvolveram quadro neurológico, caracteristicamente uma síndrome parkinsoniana. Na DG juvenil, distúrbios do movimento são freqüentemente encontrados $^{83}$, porém atualmente existe crescente evidência de que acometimento 
neurológico, especialmente parkinsonismo, pode ocorrer como uma complicação tardia também do tipo 1 da DG.

A curiosidade do achado levou pesquisadores a cogitar se, de alguma forma, pacientes com DP teriam alterações da GBA. O estudo pioneiro de Lwin et al. ${ }^{75}$ demonstrou, através da análise de amostras de cérebros de pacientes com o diagnóstico de DP, uma proporção significativamente alta de indivíduos com mutação no gene da glicocerebrosidase. $O$ achado surpreendente gerou um burburinho na comunidade científica sobre a possível confirmação deste dado em outros grupos de pacientes e o significado do mesmo. Até então, portadores heterozigotos de mutações da GBA eram considerados isentos de quaisquer manifestações clínicas, já que a DG é autossômica recessiva.

\section{7.a.Parkinsonismo em pacientes com DG - Literatura mundial}

A associação incidental de DP e DG no mesmo paciente foi descrita pela primeira vez em $1939^{94}$ e vários relatos se seguiram ${ }^{64,79,95,96}$, incluindo um do nosso grupo $^{97}$, mostrando que parkinsonismo pode se desenvolver em pacientes com DG do tipo 1 ao longo do curso de sua doença e pode até mesmo preceder o diagnóstico de DG (como no exemplo do paciente de 51 anos descrito por Machaczka et al. em 1999, no qual a síndrome parkinsoniana precedeu em 12 anos a manifestação da $\mathrm{DG}^{95}$ ). Muitos destes casos apresentavam características que não seriam esperadas na DP clássica, como início mais precoce e resposta insatisfatória à levodopa a longo prazo.

Os primeiros relatos da associação não receberam muita atenção, pois a DP, como uma doença relativamente prevalente, poderia acometer ao acaso pacientes 
com DG, mas a multiplicação do número de pacientes nos quais ambas as doenças incidiam levou os pesquisadores a se deter sobre a questão ${ }^{98}$.

Um dos primeiros relatos de sintomas neurológicos sob a forma de síndrome parkinsoniana na DG tipo 1 foi de autoria de Davidson em 1942 - um homem de 26 anos com DG tipo 1 que desenvolveu imobilidade facial ${ }^{79}$. Depois dele, outras descrições mencionando a coexistência incidental entre DG e DP se seguiram, inicialmente de forma episódica e, mais consistentemente, nas décadas de 80 e 90.

Em 1985 McKeran et al. relataram o caso de uma paciente de 55 anos, com DG tipo 1 diagnosticada aos 7 anos, que evoluiu tardiamente, aos 45 anos, com uma síndrome extrapiramidal, caracterizada por um quadro rígido-acinético sem tremor, inicialmente responsivo à levodopa ${ }^{83}$.

No estudo realizado por Neudorfer et al., publicado em 1996, foram descritos 6 pacientes com DG e parkinsonismo ${ }^{79}$. A idade média de início da síndrome parkinsoniana foi de 48,8 anos (contrastando com a idade média de 61,4 anos de início da DP em uma amostra da mesma população sem DG) e as manifestações mais comuns foram tremor, rigidez, bradicinesia, hipomimia e fala monótona. Quatro pacientes permaneceram em seguimento e observou-se serem refratários à levodopa. Dois pacientes foram submetidos a talamotomia estereotáxica para alívio dos sintomas neurológicos, com resposta apenas parcial.

Em 2003, Bembi et al. descreveram 4 pacientes com DG tipo 1 e sintomas parkinsonianos: 3 mulheres e 1 homem, com idade média de 61,7 anos, idade média de início de 50,2 anos e duração média da doença de 7,25 anos ${ }^{64}$. Dois pacientes haviam recebido o diagnóstico de DG tipo 1 em idade precoce e desenvolveram parkinsonismo muitos anos depois. Todos tinham hepatoesplenomegalia, anemia e 
trombocitopenia. As manifestações parkinsonianas eram típicas e incluíam tremor de repouso de início assimétrico, rigidez e bradicinesia, com resposta inicial favorável à levodopa e às intervenções cirúrgicas (palidotomia bilateral em um paciente, estimulação cerebral profunda em outro). A idade de início do parkinsonismo foi menor do que na forma clássica da DP em todos os pacientes. A reposição enzimática demonstrou ser eficaz em reduzir o processo de depósito periférico e corrigir as alterações hematológicas, mas não teve efeito sobre o quadro parkinsoniano. Nestes pacientes o quadro neurológico era indistinguível da DP clássica, exceto pelo início precoce.

Várkonyi et al., também em 2003, descreveram mais 4 casos em que DG e parkinsonismo ocorriam no mesmo paciente, fornecendo mais evidências de que estas condições distintas estariam de alguma forma ligadas. Todos os pacientes foram relativamente refratários ao tratamento com levodopa e a maioria teve início precoce da doença. Não houve melhora significativa dos sintomas neurológicos durante a terapia de reposição enzimática. Um dos pacientes tinha o perfil de mutações da GBA N370S/N370S, o que produziu discussão no artigo acerca do conceito vigente de que este seria um alelo protetor para manifestações neurológicas da doença ${ }^{98}$.

O mesmo grupo de Várkonyi havia descrito o desenvolvimento de parkinsonismo em um paciente húngaro com DG tipo $1^{99}$. Neste trabalho de 2002, os autores enfatizam que até então as manifestações neurológicas esperadas na DG tipo 1 eram relacionadas ao acometimento sistêmico da doença, como sangramento do sistema nervoso central (pelas alterações hematológicas próprias da DG) e complicações esqueléticas, como já havia sido relatado por Grewal et al. em 1991, na 
descrição de 8 pacientes com DG tipo 1 que, devido à coagulopatia e doença óssea secundárias à DG, desenvolveram quadros neurológicos, como plexopatia lombossacral e hematomielia espontânea ${ }^{100}$.

Tayebi et al., ainda em 2003, estudaram o gene da glicocerebrosidase em 17 pacientes com parkinsonismo e DG e encontraram 12 genótipos diferentes: 14 apresentavam a mutação comum "não-neuronopática" N370S, incluindo 5 homozigotos. Não foram identificadas mutações do gene parkin ou do gene da alfasinucleína. A maioria dos pacientes apresentava tremor, rigidez e bradicinesia. A reposição enzimática com alglucerase foi empregada em sete pacientes, sem melhora do quadro parkinsoniano. A resposta a agentes antiparkinsonianos foi modesta ou ruim. Houve possibilidade de analisar o tecido cerebral post-mortem em 4 casos, tendo sido observado um padrão típico da DP, com perda marcante de neurônios dopaminérgicos na substância negra e presença de corpos de Lewy ${ }^{96}$.

\section{7.b.Parkinsonismo em pacientes com DG - experiência do HCFMUSP}

Durante a realização do projeto, tivemos a oportunidade de acompanhar no ambulatório de Distúrbios do Movimento do HCFMUSP dois pacientes com DG que evoluíram durante o curso de sua doença com quadro de parkinsonismo.

O primeiro caso, que gerou inclusive uma publicação a respeito ${ }^{97}$, veio encaminhado do ambulatório de Hematologia do próprio Hospital das Clínicas da USP e era de um homem de 45 anos, branco, com queixa de dificuldade à marcha desde 2002. O paciente tinha o diagnóstico de DG tipo 1 desde os 22 anos de idade, quando exames de sangue de rotina haviam demonstrado anemia. Durante a investigação, o paciente foi submetido a biópsia de medula óssea, que foi sugestiva 
de DG, e posteriormente a estudo genético, que mostrou mutações N370S/L444P no gene da glicocerebrosidase. O paciente era o segundo filho de pais não consangüíneos e tinha nascido de parto normal e apresentado desenvolvimento neuropsicomotor normal na infância. Não tinha ascendência judaica e tinha história familiar negativa tanto para DP como para DG. No seguimento com o hematologista foi observada hepatoesplenomegalia e dor óssea. Em 1995 o paciente foi submetido a esplenectomia (Figura 4). Em 1998, foi iniciada terapia de reposição enzimática com imiglucerase $60 \mathrm{UI} / \mathrm{kg}$ a cada duas semanas e o paciente obteve melhora dos sintomas, além de regressão das alterações hematológicas. Com 43 anos, o paciente notou dificuldade progressiva à marcha, com redução do balanço dos braços e dificuldade para se virar. Concomitantemente, ele desenvolveu um tremor de ação assimétrico bilateral, de predomínio à esquerda, e bradicinesia. Foi prescrito levodopa/carbidopa, com melhora parcial do tremor e da marcha. Quando foi avaliado no nosso ambulatório, o paciente estava em uso de levodopa/benserazida 200/50 mg, meio comprimido cinco vezes ao dia. Pouco tempo após a introdução da medicação ele começou a apresentar discinesias. O exame físico geral não tinha alterações significativas. Ao exame neurológico, havia fraqueza moderada bilateral à dorsiflexão dos tornozelos (o paciente tinha eletroneuromiografia de 2002 com radiculopatia L4-S1 bilateral e neuropatia do nervo fibular esquerdo; tomografia computadorizada da coluna lombossacral mostrava estenose espinhal em L3-L4 estas alterações haviam sido atribuídas à DG), rigidez em roda denteada nos membros superiores e inferiores, tremor cinético bilateral leve, discinesias em membros inferiores e arreflexia de aquileus. Foi prescrito pramipexole 0,25 mg três vezes ao dia e o paciente obteve melhora sintomática leve. 


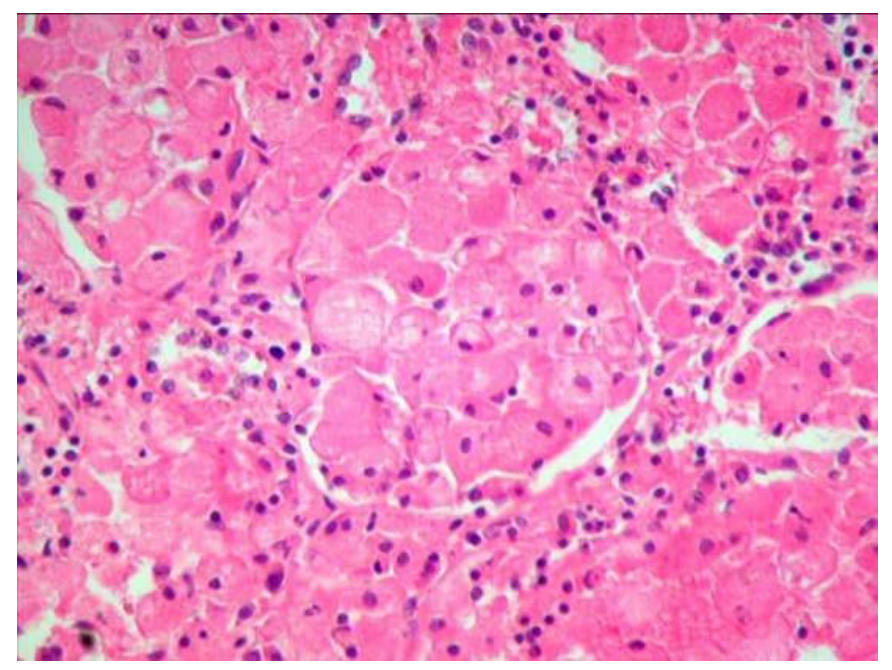

Figura 4. Histopatologia do baço do paciente com DG, evidenciando as células de Gaucher, características da doença.

Este paciente, assim como a maioria dos casos descritos na literatura, desenvolveu parkinsonismo em idade mais precoce do que a usual (43 anos). Esta parece ser uma característica consistente dos pacientes com DG tipo 1 que desenvolvem parkinsonismo. Outro ponto interessante é que o paciente desenvolveu sintomas parkinsonianos na vigência de terapia de reposição enzimática, confirmando dados previamente publicados sobre a ineficácia deste tratamento específico para DG em corrigir as manifestações neurológicas da doença. O paciente teve sintomas bilaterais desde o início e até o momento uma resposta insatisfatória ao tratamento com levodopa, o que também não seria esperado na DP clássica.

A outra paciente com DG que procurou o ambulatório veio encaminhada pela sua hepatologista. Era uma senhora de 80 anos, branca, com queixa de dificuldade para andar há 3 anos. Relatava que em 2003 havia tido quadro de dor no ombro esquerdo e que durante a investigação diagnóstica, fora solicitada uma radiografia simples do local, que teria mostrado alguma alteração que levou a paciente a ser 
submetida a uma biópsia de medula óssea, compatível com o diagnóstico de DG. Referia que desde a infância tinha anemia, equimoses pelo corpo e dores ósseas, porém tais sintomas não tinham motivado uma avaliação médica mais detalhada. Em 2004, iniciou terapia de reposição enzimática com imiglucerase a cada duas semanas. Três anos antes, notara dificuldade para movimentar o membro inferior esquerdo e, cerca de um ano depois, lentificação para as atividades que requeriam o uso da mão esquerda. Não havia queixa de tremor. Ainda em 2003 havia procurado neurologista, que prescreveu levodopa/carbidopa de liberação lenta, dois comprimidos por dia, porém os sintomas haviam permanecido inalterados. A paciente era filha de pais não consangüíneos, com origem étnica judaica (Ashkenazi). Não havia casos de DP na família e nem de DG, porém relatava que um primo, que havia recentemente feito triagem pré-natal nos Estados Unidos, havia sido identificado como portador de uma mutação da DG. Ao exame neurológico, observava-se marcha com redução do balanço passivo do braço esquerdo, discreta rigidez em roda denteada em membro superior esquerdo e discreta bradicinesia ipsilateral. Como a paciente estava sob efeito da medicação, sugeriu-se que ela retornasse dentro de uma semana, durante a qual, não deveria fazer uso de levodopa, para reavaliação. Após esse período, retornou ao ambulatório referindo piora significativa da marcha e ao exame observava-se nitidamente uma piora da rigidez e bradicinesia à esquerda. Orientado novamente o uso de levodopa. Infelizmente a paciente morava em outra cidade e optou por não seguir acompanhamento em São Paulo. 
2.7.c.Mutações da GBA em pacientes com DP

Em artigo publicado em 2004, Lwin et al. estudaram o gene da glicocerebrosidase em amostras de cérebros de 57 pacientes, provenientes de cinco bancos de cérebro dos Estados Unidos, portadores do diagnóstico de $\mathrm{DP}^{75}$. Foram identificadas alterações genéticas em 12 casos (21\%), com maior freqüência nos pacientes mais jovens, incluindo 8 (14\%) com mutações (N307S, L444P, K198T e RT329C), sendo 6 heterozigotos, e quatro com provável polimorfismo (T369M e E326K - estas alterações são consideradas polimorfismos porque só foram identificadas em pacientes que carreavam outra mutação no mesmo alelo). Dentre 44 amostras de cérebros de controles, emparelhados para idade, sem evidência patológica de DP, 2 tinham o alelo E326K, mas não foram identificadas mutações. O estudo sugeriu que mutações da GBA podem ser um fator de risco para o desenvolvimento de parkinsonismo, mesmo em heterozigose.

Em estudo publicado ainda em 2004, Aharon-Peretz et al. pesquisaram as seis mutações mais comuns da glicocerebrosidase em judeus Ashkenazi em 99 pacientes de Israel com DP idiopática e a origem étnica em questão e encontraram em 31 deles $(31,3 \%)$ mutação em um ou dois alelos, valor significativamente maior (mais que cinco vezes) do que nos controles $(\mathrm{p}<0,001)$ - 95 carreadores em 1543 indivíduos sugerindo que inclusive heterozigose para mutações da GBA pode predispor a parkinsonismo $^{3}$. A maioria dos pacientes com as mutações (23) eram heterozigotos para N370S, porém 3 eram homozigotos N370S/N370S, no entanto sem sintomas compatíveis com DG e sem terem recebido este diagnóstico em qualquer momento. Entre os pacientes com DP, portadores de mutações da GBA eram mais jovens do que os não portadores $(\mathrm{P}=0,04)$. 
Em resposta a este artigo, Zimran et al. enfatizaram a importância da interpretação adequada dos achados, pois os dados publicados acerca da incidência significativa de parkinsonismo de início precoce entre carreadores de mutações da DG poderia desencadear o estabelecimento de políticas de triagem em larga escala entre judeus Ashkenazi e potencialmente levar a recomendações para terapia de reposição enzimática neste grupo meramente pela prevenção hipotética de doença neurológica. Como essa situação teria implicações enormes nos níveis pessoal e social, os autores insistiram que, antes de aceitos como absolutos, os dados deveriam ser confirmados em estudos em larga escala ${ }^{101}$.

Sidransky e outros pesquisadores do NIH (National Institute of Health), que constituem um dos expoentes mundiais no estudo da DG e da associação DG x DP, seqüenciaram, em 2005, o gene da glicocerebrosidase em 26 amostras de cérebros do Banco de Cérebros de Londres de pacientes com diagnóstico de DP e encontraram 2 (8\%) que carreavam mutações da glicocerebrosidase ${ }^{57}$. Estes achados, baseados em diagnósticos definitivos de autópsia, reforçaram a idéia de que a heterozigose para mutações da GBA pode ser um fator de risco para parkinsonismo, não apenas em judeus Ashkenazi. O grupo de Sidransky, em um estudo de 2004, havia descrito 10 famílias de indivíduos com DG em que carreadores obrigatórios ou confirmados de mutações da GBA desenvolveram parkinsonismo ${ }^{102}$. Em todas as famílias, os sintomas parkinsonianos apareciam em uma idade precoce, freqüentemente com um curso atípico. Foram identificadas diversas mutações nestas famílias, indicando que a predisposição a parkinsonismo em indivíduos heterozigotos para mutações da DG não pode ser atribuída a uma mutação específica. 
Dois outros estudos publicados em 2005 tentaram estabelecer a presença da associação DP x DG em outras populações. O primeiro, realizado nos Estados Unidos por Clark et al., avaliou 160 pacientes de Nova York com DP, de ascendência judaica Ashkenazi, e 92 controles emparelhados para idade e sexo, com a mesma origem étnica, e encontrou mutações N370S da glicocerebrosidase em 17 deles (10,7\%), incluindo 2 homozigotos e 15 heterozigotos, versus 4,3\% nos controles. Este valor não alcançou significância estatística nesta amostra ${ }^{103}$. No Canadá, Sato et al. estudaram 88 pacientes com DP, selecionados para idade de início precoce ou história familiar positiva, pesquisaram 7 mutações da GBA, e identificaram mutações em 5,6\% dos pacientes (N370S e L444P) e em 1 de 122 controles (N370S), correspondendo a $0,8 \%$ do total, obtendo como resultado uma associação marginalmente significativa entre DP e mutações da glicocerebrosidase nesta população $(\mathrm{P}=0,048)$. Os pacientes com a mutação tinham manifestações típicas da DP, com início assimétrico e boa resposta à levodopa ${ }^{104}$.

Um recente estudo retrospectivo conduzido na Noruega em 2006 encontrou uma frequiência semelhante de mutações da GBA (tendo sido pesquisadas N370S e L444P) entre 311 pacientes com DP $(7=2,3 \%)$ e um grupo controle de 474 indivíduos da mesma área $(8=1,7 \%)$, contradizendo a associação causal entre estas duas doenças na população estudada. Todos os pacientes com a mutação tinham um fenótipo parkinsoniano típico e boa resposta à levodopa. A idade média de início da doença era de 56,9 anos, comparável à do grupo total ${ }^{4}$.

Ainda em 2006, Eblan et al. avaliaram um grupo etnicamente diferente de 33 pacientes diagnosticados com DP de início precoce, acompanhados no Hospital de Caracas, na Venezuela ${ }^{100}$. Nesta coorte, a idade de início dos sintomas variou de 24 a 
50 anos. Nenhum dos indivíduos tinha ascendência judaica Ashkenazi. Após seqüenciamento do gene da GBA, detectou-se a presença de mutações em 4 (12\%), todos com resposta favorável à levodopa. Posteriormente foram analisados 41 pacientes adultos sem sinais clínicos de parkinsonismo. Um controle $(3,2 \%)$ carreava uma alteração da GBA. Os autores sugeriram que mutações da GBA são observadas com frequiência aumentada não apenas em judeus Ashkenazi com DP, mas também em indivíduos com parkinsonismo e origem étnica diversa.

A Tabela 3 mostra um resumo dos trabalhos publicados sobre a associação DP x DG e seu desenho experimental. Cinco artigos descreveram uma frequiência maior do que a esperada de diferentes mutações causadoras de DG em pacientes com DP em diferentes populações e um artigo não confirmou a presença desta associação.

Com base nestes achados e cientes da importância desta associação para um maior entendimento da fisiopatologia da DP, buscou-se neste trabalho descrever a análise das mutações mais comuns da DG em 65 pacientes brasileiros com DP, comparados a um grupo controle emparelhado para idade e sexo, composto de 267 indivíduos. 


\begin{tabular}{|c|c|c|c|c|}
\hline Referência & $\begin{array}{l}\text { População } \\
\text { estudada }\end{array}$ & $\begin{array}{c}\text { Mutações da GBA } \\
\text { analisadas }\end{array}$ & Resultados & Grupo controle \\
\hline $\begin{array}{c}\text { Lwin et al., } \\
2004\end{array}$ & $\begin{array}{c}\text { Amostras de } \\
\text { cérebros de } 57 \\
\text { pacientes com } \\
\text { DP }\end{array}$ & $\begin{array}{l}\text { Seqüenciamento } \\
\text { completo do gene }\end{array}$ & $\begin{array}{c}8 \text { pacientes }(14 \%) \\
\text { com mutações da } \\
\text { GBA: } 2 \text { homozigotos } \\
\text { (N370S/N370S) e } 6 \\
\text { heterozigotos }\end{array}$ & $\begin{array}{c}\text { Presença apenas de dois } \\
\text { portadores de E326K } \\
\text { sem outras mutações da } \\
\text { GBA em amostras de } \\
\text { cérebro de } 44 \text { pacientes } \\
\text { adultos sem DP. }\end{array}$ \\
\hline $\begin{array}{l}\text { Aharon- } \\
\text { Peretz et } \\
\text { al., } 2004\end{array}$ & $\begin{array}{c}99 \text { pacientes } \\
\text { judeus de Israel } \\
\text { com DP }\end{array}$ & $\begin{array}{c}6 \text { mutações: } \\
\text { N370S, L444P, } \\
\text { 84insG, Ivs2+1g>a, } \\
\text { V394L e R496H }\end{array}$ & $\begin{array}{c}31 \text { pacientes }(31 \%) \\
\text { com mutações da } \\
\text { GBA: } \\
3 \text { homozigotos e } 28 \\
\text { heterozigotos }\end{array}$ & $\begin{array}{c}\text { Grupo controle de } 1543 \\
\text { judeus, com presença de } \\
95 \text { carreadores, um valor } \\
5 \text { vezes menor que o dos } \\
\text { pacientes com DP. }\end{array}$ \\
\hline $\begin{array}{c}\text { Clark et al., } \\
2005\end{array}$ & $\begin{array}{c}160 \text { pacientes } \\
\text { judeus de Nova } \\
\text { York com DP }\end{array}$ & $\begin{array}{l}1 \text { mutação: } \\
\text { N370S }\end{array}$ & $\begin{array}{l}17 \text { pacientes }(11 \%) \\
\text { com mutações da } \\
\text { GBA: } \\
2 \text { homozigotos e } 15 \\
\text { heterozigotos }\end{array}$ & $\begin{array}{c}\text { Grupo controle de } 92 \\
\text { judeus, com freqüência } \\
\text { de mutação de } 4 \% \text {, uma } \\
\text { diferença sem } \\
\text { significância estatística } \\
(\mathrm{P}=0.2)\end{array}$ \\
\hline $\begin{array}{l}\text { Sato et al., } \\
2005\end{array}$ & $\begin{array}{c}88 \text { pacientes } \\
\text { canadenses com } \\
\text { DP }\end{array}$ & $\begin{array}{c}7 \text { mutações: } \\
\text { N370S, L444P, } \\
\text { 84insG, Ivs2+1g>a, } \\
\text { K198T, R329C e } \\
\text { Rec }\end{array}$ & $\begin{array}{c}5 \text { pacientes }(5,6 \%) \\
\text { com mutações da } \\
\text { GBA em heterozigose }\end{array}$ & $\begin{array}{c}\text { Grupo controle }(\mathrm{n}=122) \\
\text { com frequiência de } \\
\text { mutação de } 0,8 \%, \text { uma } \\
\text { diferença marginalmente } \\
\text { significativa }(\mathrm{P}=0.048)\end{array}$ \\
\hline $\begin{array}{c}\text { Toft et al., } \\
2006\end{array}$ & $\begin{array}{l}311 \text { pacientes } \\
\text { noruegueses } \\
\text { com DP }\end{array}$ & $\begin{array}{c}2 \text { mutações: N370S } \\
\text { e L444P }\end{array}$ & $\begin{array}{c}7 \text { pacientes }(2,3 \%) \\
\text { com mutações da } \\
\text { GBA em heterozigose }\end{array}$ & $\begin{array}{c}\text { Grupo controle }(\mathrm{n}=474) \\
\text { com frequiência de } \\
\text { mutação de } 1,7 \%, \text { uma } \\
\text { diferença sem } \\
\text { significância estatística } \\
\qquad(\mathrm{P}=0,58)\end{array}$ \\
\hline $\begin{array}{c}\text { Eblan et al., } \\
2006\end{array}$ & $\begin{array}{c}33 \text { pacientes } \\
\text { venezuelanos } \\
\text { com DP }\end{array}$ & $\begin{array}{l}\text { Seqüenciamento } \\
\text { completo do gene }\end{array}$ & $\begin{array}{c}4 \text { pacientes }(12 \%) \\
\text { com mutações da } \\
\text { GBA em heterozigose }\end{array}$ & $\begin{array}{l}\text { Grupo controle }(\mathrm{n}=31) \\
\text { com freqüência de } \\
\text { mutação de } 3,2 \% \text {. Sem } \\
\text { descrição de } \mathrm{P} \text {. }\end{array}$ \\
\hline
\end{tabular}

Tabela 3. Resumo dos estudos já publicados sobre mutações da GBA em pacientes com DP. 


\section{MÉTODOS}

O estudo consistiu na avaliação clínica e genética de 65 pacientes com DP em seguimento no ambulatório de Distúrbios do Movimento do Hospital das Clínicas da Faculdade de Medicina da Universidade de São Paulo (HCFMUSP) e a posterior comparação dos resultados com aqueles obtidos a partir da análise de 267 controles, constituídos por pacientes e acompanhantes de pacientes, sem DP, entrevistados nos ambulatórios do Hospital das Clínicas da USP, emparelhados para sexo e idade.

\subsection{Da seleção de pacientes com DP e grupo controle}

Foram analisadas amostras de DNA de 65 pacientes com o diagnóstico de DP idiopática acompanhados no ambulatório de Distúrbios do Movimento do HCFMUSP. O diagnóstico da doença baseou-se nos critérios do Banco de Cérebro de Londres $^{106,107,108}$ (United Kingdom Parkinson's Disease Society Brain Bank clinical criteria - Anexo A), com exceção do critério de exclusão para pacientes com história familiar positiva de DP, que inclusive vem sendo questionado por vários autores e desconsiderado também em outros trabalhos genéticos ${ }^{109}$.

Antes de o paciente integrar o estudo, era explicado ao mesmo os objetivos e modo de funcionamento do projeto, cabendo ao paciente interessado em colaborar assinar um termo de consentimento (Anexo B), onde se encontrava devidamente esclarecido o direito de o paciente desistir da participação no estudo, sem qualquer forma de prejuízo para seu tratamento. Os pacientes participantes respondiam a um questionário do qual constavam, entre outras, informações relativas a nome, data e local de nascimento, nome dos pais e respectivos locais de nascimento, endereço, telefone, e-mail, existência de consangüinidade entre os pais, origem étnica, número 
de irmãos, história familiar de parkinsonismo, primeiros sintomas da doença e resposta à levodopa. Foram selecionados pacientes com idade de início da doença antes de 55 anos, com base nos estudos iniciais sobre a associação entre DP e DG, que sugeriam que os pacientes com DP portadores de mutações da GBA teriam um início mais precoce do que o usual da doença ${ }^{64,79}$.

Um grupo controle de 267 indivíduos foi obtido, emparelhado para idade e sexo com a amostra de pacientes com DP. Este grupo de indivíduos, entrevistados em ambulatórios do HCFMUSP que não o de Neurologia, não apresentava diagnóstico conhecido de DG, DP ou qualquer outra doença neurológica.

Nenhum dos participantes do estudo tinha ascendência judaica, uma população que representa somente cerca de $0,05 \%$ da população brasileira total ${ }^{110}$. Análises estatísticas foram realizadas utilizando o teste exato de Fischer.

Todos os pacientes e controles voluntários para a pesquisa foram orientados a assinar um termo de consentimento informado. O projeto foi aprovado pelo Comitê de Ética do HCFMUSP (Anexo C).

\subsection{Da análise laboratorial}

O DNA dos pacientes foi extraído de material obtido a partir da mucosa da boca, de acordo com Richards et al. ${ }^{86}$. A coleta foi realizada através da raspagem de mucosa jugal com uma haste flexível durante um período médio de dez segundos, seguida de corte do segmento da haste em que se depositou o material com uma tesoura e colocação deste dentro de um tubo devidamente fechado, contendo $\mathrm{NaOH}$. A determinação da forma de coleta do material (mucosa bucal versus sangue) foi definida pelo laboratório de Genética Molecular do Departamento de Biologia da 
Universidade de São Paulo, onde a análise laboratorial foi realizada, com o respaldo da literatura, conforme descrito na introdução (página 35).

Em todos os pacientes e controles foram pesquisadas as mutações N370S e L444P, as mais freqüentes no mundo todo. A mutação G377S é a terceira mais freqüente em Portugal e no Brasil, optando-se por também incluí-la na análise inicial. As mutações pesquisadas estão presentes em cerca de $75 \%$ dos alelos dos pacientes com DG no Brasil ${ }^{111}$. Os pacientes puderam ter acesso ao resultado da análise, de acordo com a vontade previamente declarada no termo de consentimento.

Pacientes nos quais a mutação L444P era detectada, tinham suas amostras posteriormente analisadas para V460V e também E326K, de forma a detectar, respectivamente, alelos recombinantes (pseudogene derived mutations) e alelos complexos (vide introdução).

As mutações foram pesquisadas através do método de amplificação do DNA por PCR (polymerase chain reaction) e digestão dos produtos com enzimas de restrição específicas para cada mutação. A análise molecular foi baseada em polimorfismos de restrição de fragmento por comprimento (restriction fragment length polymorphisms). A estratégia de triagem, os primers (pequenos oligonucleotídeos utilizados para iniciar a replicação das fitas de DNA, necessários para o seqüenciamento de DNA e PCR) e as endonucleases de restrição usadas para a detecção de mutações e o método de referência quando previamente estabelecido são descritos na Tabela 4. Após a digestão por endonucleases, os fragmentos eram submetidos a eletroforese, sendo utilizado gel de poliacrilamida a $12 \%$ para pesquisa das mutações N370S e G377S e gel de agarose a $2 \%$ para pesquisa das mutações 
L444P, V460V e E326K. Controles positivos e negativos foram incluídos em todos os ensaios.

Maiores explicações acerca dos procedimentos utilizados para o processamento das amostras encontram-se no Anexo $\mathrm{D}^{112,113,114}$.

\begin{tabular}{|c|c|c|c|}
\hline $\begin{array}{c}\text { Mutação } \\
\text { (seqüência } \\
\text { do DNA) }\end{array}$ & Grupo analisado & Primers & $\begin{array}{c}\text { Endonuclease de } \\
\text { restrição }\end{array}$ \\
\hline $\begin{array}{c}\mathrm{N370S} \\
(\mathrm{c.1226A}>\mathrm{G})\end{array}$ & $\begin{array}{c}\text { Todos os pacientes e } \\
\text { controles }\end{array}$ & $\begin{array}{l}\text { F: 5' }{ }^{\prime} \text { gctttgtccttacctctcg } 3^{\prime} \\
\text { R: } 5^{\prime} \text { acgaaagttacgcaccaatt } 3^{\prime} \\
\text { (39) }\end{array}$ & XhoI \\
\hline $\begin{array}{c}\text { G377S } \\
(\text { c.1246G }>A)\end{array}$ & $\begin{array}{c}\text { Todos os pacientes e } \\
\text { controles }\end{array}$ & $\begin{array}{l}\text { F: } 5^{\prime} \text { gcctttgtccttaccctcg } 3^{\prime} \\
\text { R: } 5^{\prime} \text { acgaaagttacgcacccaatt } 3^{\prime}\end{array}$ & AluI ou PvuII \\
\hline $\begin{array}{c}\text { L444P } \\
(\text { c.1448T }>C)\end{array}$ & $\begin{array}{c}\text { Todos os pacientes e } \\
\text { controles }\end{array}$ & $\begin{array}{l}\text { F: 5'ctgaaccccgaaggaggac } 3^{\prime} \\
\text { R: } 5^{\prime} \text { tgaatggagtagccaggtga } 3^{\prime} \\
(40)\end{array}$ & NciI \\
\hline $\begin{array}{c}\mathrm{V} 460 \mathrm{~V} \\
(\mathrm{c} .1497 \mathrm{G}>\mathrm{C})\end{array}$ & $\begin{array}{l}\text { Pacientes com } \\
\text { L444P }\end{array}$ & $\begin{array}{l}\text { F: } 5^{\prime} \text { ctgaaccccgaaggaggac } 3^{\prime} \\
\text { R: } 5^{\prime} \text { tgaatggagtagccaggtga } 3^{\prime}\end{array}$ & BcgI \\
\hline $\begin{array}{c}\text { E326K } \\
(\text { c.1093G }>A)\end{array}$ & $\begin{array}{l}\text { Pacientes com } \\
\quad \text { L444P }\end{array}$ & $\begin{array}{l}\text { Primeiro PCR: } \\
\text { F: 5'acaaattagctgggtgtggc } 3^{\prime} \\
\text { R: 5'taagctcacactggccetgc } 3^{\prime} \\
\text { Segundo PCR: } \\
\text { F: 5'tgtgcaaggtccaggatcag } 3^{\prime} \\
\text { R: 5'gaggtctgcttgcaggaag } 3^{\prime}\end{array}$ & BbsI ou BpiI \\
\hline
\end{tabular}

Tabela 4. Estratégias de detecção das mutações da GBA analisadas 


\section{RESULTADOS}

Dentre os 65 pacientes com DP incluídos no estudo, a idade no momento da avaliação variou de 30 a 76 anos: 41 eram do sexo masculino e 24 do sexo feminino, uma proporção estabelecida para se equivaler à maior prevalência da doença em homens. Somente um paciente foi selecionado de cada família. A idade de início dos sintomas parkinsonianos variou de 12 a 55 anos (Figura 5). Quatorze pacientes $(21,5 \%)$ tinham história familiar positiva para DP (Figura 6) e cinco $(7,7 \%)$ tinham pais consangüíneos. Não havia casos com antecedente de traumatismo craniano moderado ou grave. O grau de escolaridade teve grande variação, assim como a ocupação profissional. Nenhum dos participantes do estudo tinha ascendência judaica, uma população que representa somente cerca de $0,05 \%$ da população brasileira total. Os sintomas iniciais da DP são mostrados na Figura 7. Um total de 94\% dos pacientes tinha assimetria dos sinais motores no início da doença.

\section{Idade de início da DP}

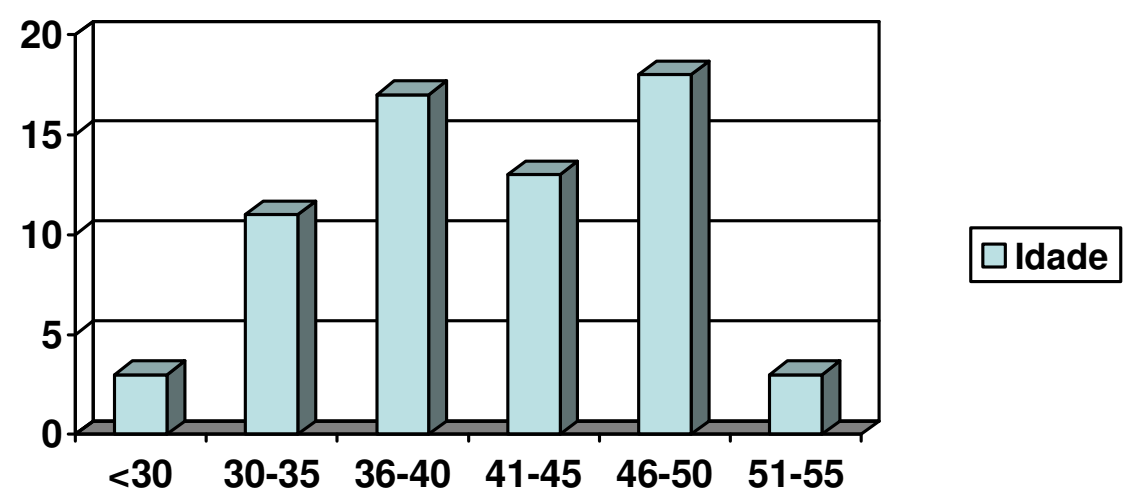

Figura 5. Idade de início da DP 


\section{História familiar de DP}

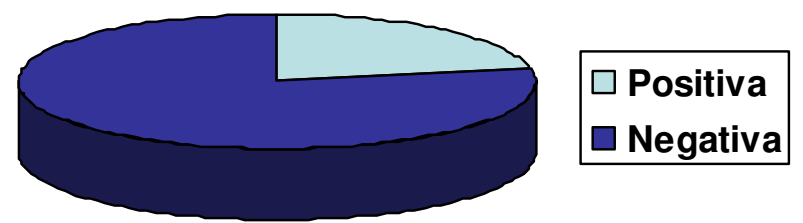

Figura 6. História familiar de DP dentre os pacientes estudados.

\section{Sintoma inicial}

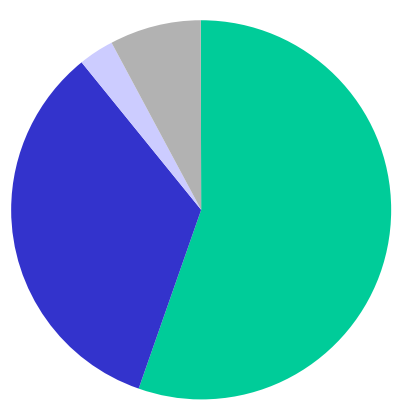

\begin{tabular}{|l|}
\hline Tremor \\
Rigidez \\
Bradicinesia \\
Outros \\
\hline
\end{tabular}

Figura 7. Sintoma inicial da DP nos pacientes estudados.

A Tabela 5 mostra as características dos 65 pacientes com DP que foram incluídos no presente estudo.

Os 267 controles que integraram a pesquisa também tinham idades que variavam de 30 a 76 anos, não possuíam diagnóstico de DP, e apresentavam uma relação homem:mulher de aproximadamente 1,75, semelhante ao observado nos pacientes. Nenhum dos indivíduos tinha ascendência judaica. Onze deles $(4,1 \%)$ relatavam consangüinidade dos pais. Tanto no grupo controle como entre os 
pacientes, a grande maioria dos participantes não sabia informar acerca da origem étnica da família.

Entre os 65 pacientes com DP analisados, foram encontrados dois heterozigotos (3\%) para DG. A Tabela 6 mostra os dados clínicos destes pacientes carreadores de mutações da DG. Os dois heterozigotos detectados tinham a mutação L444P, sendo que um deles apresentava também E326K. Ambos eram homens e com história familiar positiva para DP. O primeiro (paciente 1, número 20 na Tabela 5) é um homem de 64 anos, cujo sintoma inicial da DP foi tremor na mão esquerda aos 46 anos. Sua mãe e avô materno também eram afetados. Ele tem uma progressão lenta da doença e mantém uma boa resposta à levodopa após quase duas décadas de tratamento. O outro paciente (paciente 2, número 26 na Tabela 5) é um homem de 56 anos, cuja manifestação inicial da doença foi dor e rigidez em MSD aos 42 anos.

\begin{tabular}{|l|l|l|l|l|l|l|l|}
\hline Paciente & Sexo & Idade & \multicolumn{1}{|c|}{$\begin{array}{c}\text { História familiar } \\
\text { de DP }\end{array}$} & $\begin{array}{c}\text { Idade } \\
\text { de } \\
\text { início }\end{array}$ & \multicolumn{1}{|c|}{$\begin{array}{c}\text { Forma } \\
\text { de início }\end{array}$} & $\begin{array}{c}\text { Sintoma } \\
\text { Inicial }\end{array}$ & $\begin{array}{c}\text { Resposta } \\
\text { à } \\
\text { levodopa }\end{array}$ \\
\hline 1 & M & 55 & Não & 47 & Assimétrico E & Rigidez & Sim \\
\hline 2 & M & 59 & Não & 45 & Assimétrico D & Tremor & Sim \\
\hline 3 & M & 62 & Não & 55 & Assimétrico D & Rigidez & Sim \\
\hline 4 & M & 76 & Não & 50 & Assimétrico E & Tremor & Sim \\
\hline 5 & M & 50 & Não & 40 & Assimétrico D & Tremor & Sim \\
\hline 6 & M & 64 & Não & 49 & Assimétrico E & Rigidez & Sim \\
\hline 7 & M & 44 & Não & 38 & Assimétrico D & Tremor & Sim \\
\hline 8 & F & 53 & Não & 42 & Assimétrico E & Tremor & Sim \\
\hline 9 & M & 40 & Não & 38 & Assimétrico D & Rigidez & Sim \\
\hline 10 & M & 55 & Não & 36 & Assimétrico D & Tremor & Sim \\
\hline 11 & F & 67 & Não & 43 & Simétrico & Peso & Sim \\
\hline 12 & M & 57 & Não & 40 & Assimétrico D & Tremor & Sim \\
\hline 13 & M & 51 & Não & 38 & Assimétrico D & Rigidez & Sim \\
\hline 14 & F & 43 & Não & 42 & Assimétrico D & Não sabe & Não usa \\
\hline 15 & M & 65 & Não & 46 & Assimétrico D & Bradicinesia & Sim \\
\hline 16 & M & 63 & Não & 36 & Assimétrico E & Rigidez & Sim \\
\hline 17 & M & 68 & Sim, avó paterna & 26 & Assimétrico D & Tremor & Sim \\
\hline 18 & M & 32 & Não & 38 & Assimétrico D & Tremor & Sim \\
\hline 19 & M & 61 & Não & 46 & Assimétrico E & Tremor & Sim \\
\hline $20 *$ & M & 61 & Sim, mãe e avô materno & & & & Sim \\
\hline
\end{tabular}




\begin{tabular}{|c|c|c|c|c|c|c|c|}
\hline 21 & $\mathrm{~F}$ & 50 & Não & 38 & Assimétrico E & Tremor & Sim \\
\hline 22 & $\mathrm{M}$ & 58 & Sim, tia materna & 49 & Assimétrico D & Tremor & Sim \\
\hline 23 & $\mathrm{M}$ & 52 & Não & 45 & Assimétrico E & Rigidez & Sim \\
\hline 24 & $\mathrm{M}$ & 58 & Não & 37 & Assimétrico E & Rigidez & Sim \\
\hline 25 & $\mathrm{M}$ & 44 & Não & 34 & Simétrico & Tremor & Sim \\
\hline $26^{*}$ & $\mathrm{M}$ & 54 & Sim, pai & 42 & Assimétrico D & Rigidez & Sim \\
\hline 27 & $\mathrm{~F}$ & 63 & Não & 50 & Assimétrico D & Rigidez & Sim \\
\hline 28 & $\mathrm{M}$ & 56 & Sim, irmão & 40 & Assimétrico E & Rigidez & Não usa \\
\hline 29 & $\mathrm{~F}$ & 30 & Sim, 5 primos & 12 & Simétrico & Tremor & Sim \\
\hline 30 & $\mathrm{~F}$ & 68 & Sim, pai & 53 & Assimétrico D & Bradicinesia & Sim \\
\hline 31 & $\mathrm{M}$ & 69 & Não & 47 & Assimétrico E & Tremor & Sim \\
\hline 32 & $\mathrm{M}$ & 69 & Não & 50 & Assimétrico E & Rigidez & Sim \\
\hline 33 & $\mathrm{M}$ & 49 & Não & 35 & Assimétrico D & Rigidez & Sim \\
\hline 34 & $\mathrm{M}$ & 59 & Não & 45 & Assimétrico E & Rigidez & Sim \\
\hline 35 & $\mathrm{~F}$ & 50 & Não & 43 & Assimétrico E & Rigidez & Sim \\
\hline 36 & $\mathrm{M}$ & 56 & Sim, tia materna & 41 & Assimétrico E & Tremor & Sim \\
\hline 37 & $\mathrm{M}$ & 57 & Não & 45 & Assimétrico E & Tremor & Sim \\
\hline 38 & $\mathrm{~F}$ & 39 & Não & 35 & Assimétrico E & Rigidez & Sim \\
\hline 39 & $\mathrm{~F}$ & 55 & Não & 35 & Assimétrico E & Tremor & Sim \\
\hline 40 & $\mathrm{~F}$ & 72 & Não & 49 & Assimétrico D & Tremor & Sim \\
\hline 41 & $\mathrm{~F}$ & 49 & Não & 36 & Assimétrico E & Tremor & Sim \\
\hline 42 & $\mathrm{~F}$ & 52 & Sim, tio materno & 46 & Assimétrico D & Tremor & Sim \\
\hline 43 & $\mathrm{~F}$ & 50 & Não & 38 & Assimétrico D & Peso & Sim \\
\hline 44 & $\mathrm{~F}$ & 45 & Não & 39 & Assimétrico D & Tremor & Sim \\
\hline 45 & $\mathrm{~F}$ & 71 & Não & 48 & Assimétrico D & Tremor & Sim \\
\hline 46 & $\mathrm{M}$ & 62 & Não & 44 & Assimétrico D & Tremor & Sim \\
\hline 47 & $\mathrm{M}$ & 57 & Não & 49 & Assimétrico E & Rigidez & Sim \\
\hline 48 & $\mathrm{~F}$ & 61 & Sim, mãe e 2 tias maternas & 46 & Assimétrico E & Rigidez & Sim \\
\hline 49 & $\mathrm{M}$ & 56 & Não & 48 & Assimétrico E & Tremor & Sim \\
\hline 50 & $\mathrm{M}$ & 58 & Sim, irmão & 28 & Assimétrico E & Rigidez & Sim \\
\hline 51 & $\mathrm{M}$ & 53 & Não & 35 & Assimétrico E & Câimbra & Sim \\
\hline 52 & $\mathrm{M}$ & 59 & Não & 50 & Assimétrico E & Tremor & Sim \\
\hline 53 & $\mathrm{~F}$ & 44 & Não & 36 & Assimétrico D & Tremor & Sim \\
\hline 54 & $\mathrm{M}$ & 38 & Não & 38 & Assimétrico E & Tremor & Sim \\
\hline 55 & $\mathrm{M}$ & 36 & Não & 33 & Assimétrico D & Tremor & Sim \\
\hline 56 & $\mathrm{~F}$ & 51 & Não & 38 & Simétrico & Rigidez & Não usa \\
\hline 57 & $\mathrm{M}$ & 65 & Não & 48 & Assimétrico E & Tremor & Sim \\
\hline 58 & $\mathrm{M}$ & 72 & Não & 44 & Assimétrico E & Tremor & Sim \\
\hline 59 & $\mathrm{~F}$ & 42 & Não & 35 & Assimétrico E & Tremor & Sim \\
\hline 60 & $\mathrm{~F}$ & 38 & Sim, tio paterno & 30 & Assimétrico D & Rigidez & Sim \\
\hline 61 & $\mathrm{~F}$ & 43 & Sim, tio e prima maternos & 40 & Assimétrico E & Rigidez & Sim \\
\hline 62 & $\mathrm{~F}$ & 46 & Não & 34 & Assimétrico E & Tremor & Não usa \\
\hline 63 & $\mathrm{M}$ & 57 & Não & 53 & Assimétrico D & Tremor & Sim \\
\hline 64 & $\mathrm{~F}$ & 55 & Não & 34 & Assimétrico E & Tremor & Sim \\
\hline 65 & $\mathrm{M}$ & 35 & Sim, pai & 34 & Assimétrico D & Tremor & Não usa \\
\hline
\end{tabular}

Tabela 5. Características dos 65 pacientes com DP que integraram o presente estudo.

Ambos os pacientes com DP nos quais mutações da GBA foram encontradas tiveram amostras de sangue enviadas para dosagem da atividade de 
glicocerebrosidase no Hospital de Clínicas de Porto Alegre (Anexo E). Tanto o paciente 1 como o 2 obtiveram níveis de glicocerebrosidase dentro dos limites esperados para heterozigotos (Anexo F). Apesar do início precoce da DP (42 e 46 anos), estes pacientes tinham um quadro clínico indistinguível da DP clássica e foram tratados com levodopa, com boa resposta. Em ambos, o início da doença foi assimétrico e não havia características atípicas.

Nenhum heterozigoto foi encontrado entre os 267 controles. Foi comparada a freqüência de heterozigotos para as mutações de DG entre os pacientes com DP (2 em 65) e o grupo controle (0 em 267) e a diferença foi estatisticamente significativa $(\mathrm{P}=0,0379$, Teste exato de Fisher; odds ratio=21.06; intervalo de confiança $=99 \%$, 1.05 a 420.89).

\begin{tabular}{|l|l|l|}
\hline & Paciente 1 & Paciente 2 \\
\hline Mutação da GBA & L444P & L444P + E326K \\
\hline História familiar & Mãe e avô materno & Pai (início de DP aos 65 anos) \\
\hline Idade atual & 64 anos & 56 anos \\
\hline Idade de início da DP & 46 anos & 42 anos \\
\hline Sintomas iniciais & $\begin{array}{l}\text { Tremor na mão } \\
\text { esquerda }\end{array}$ & $\begin{array}{l}\text { Dor e rigidez no membro superior } \\
\text { direito }\end{array}$ \\
\hline Resposta à levodopa & Boa & Boa \\
\hline
\end{tabular}

Tabela 6: Perfil dos pacientes com DP carreadores de mutações da GBA. 


\section{DISCUSSÃO}

5.1.Da interpretação dos resultados

Após a descrição inicial da associação entre DP e mutações da GBA, vários estudos procuraram esclarecer se os pacientes com DP realmente teriam uma freqüência aumentada de mutações causadoras da DG. Na maioria dos estudos encontrou-se uma freqüência aumentada destas mutações, variando de 5 a $30 \%$ (Tabela 3), mas nem todos dispunham de um grupo controle apropriado. Em alguns casos a diferença estatística foi pouco significativa e, em artigo recente, Toft et al. não encontraram aumento de susceptibilidade à DP entre os carreadores de mutações da GBA na Noruega ${ }^{4}$, tornando o tema ainda mais controverso.

O presente estudo indica um resultado diferente do norueguês na população brasileira, tendo sido encontrados 3\% de heterozigotos para mutações da GBA entre 65 pacientes com DP. A análise estatística confirma que, apesar de pequeno, houve aumento significativo da freqüência, quando obtido e analisado um grupo controle de 267 indivíduos emparelhados para idade e sexo. A partir destes dados, há evidências de que as mutações da DG contribuem em algum grau para o desenvolvimento de DP em certos indivíduos. Dessa forma, mutações da GBA podem constituir um fator de susceptibilidade para DP no Brasil.

Alguns aspectos merecem ser enfatizados ao se inserir o estudo brasileiro no contexo das publicações mundiais:

1) Origem étnica da população analisada

Alguns estudos que avaliaram a freqüência de mutações da GBA em pacientes com DP foram restritos a judeus Ashkenazi, uma população em que sabidamente existe alta incidência de DG, estimada em 1 para 10.000 indivíduos $^{62}$. A freqüência 
de carreadores de alelos causadores da DG é estimada em 0,0343 em judeus Ashkenazi $^{61}$, valor bem acima do encontrado na população geral. Esta alta prevalência pode ter influenciado os resultados de alguns dos estudos realizados, que demonstraram uma alta freqüência de mutações da GBA em pacientes com DP nesta população. Exemplificam esta situação os estudos de Aharon-Peretz et al. ${ }^{3}$, que analisaram apenas judeus Ashkenazi de Israel, e de Clark et al. ${ }^{103}$, que incluíram 160 pacientes com DP e 92 controles de Nova York, todos com os quatro avós judeus (neste caso não houve interrogação específica acerca do subgrupo étnico, mas os autores consideraram que cerca de $90 \%$ dos judeus nos Estados Unidos são Ashkenazi).

Por outro lado, a DG é muito rara no Brasil. O único artigo publicado acerca da prevalência da DG no Brasil, datado de 2005, identificou 412 pacientes com o diagnóstico em questão no país, a grande maioria do tipo 1, com concentração maior nas regiões Sudeste, Sul e Nordeste, o que resulta em aproximadamente $1 \mathrm{em}$ 400.000 indivíduos afetados pela doença ${ }^{115}$. Desta forma, os achados deste estudo mostraram uma freqüência maior de mutações de DG entre os pacientes com DP quando comparados a um grupo controle, em uma população com baixa prevalência de DG.

No presente estudo, a origem étnica da amostra analisada foi diversa e difícil de caracterizar, pela reconhecida multiplicidade étnica existente no país, implicando em um revés na definição étnica dos participantes, tanto por parte dos investigadores como dos próprios indivíduos entrevistados.

Sato et al. ${ }^{104}$, em seu estudo, avaliaram 88 pacientes com DP sem parentesco entre si, todos canadenses de origem caucasiana, e 122 controles da mesma 
população. Toft et al. ${ }^{4}$ definiram a população que integrou seu estudo - 311 pacientes com DP e 474 controles - como homogênea e "etnicamente norueguesa".

O estudo de Eblan et al. ${ }^{105}$, realizado na Venezuela, assim como o presente estudo, não tinha entre seus participantes nenhum com ascendência judaica, e a amostra avaliada também foi classificada como etnicamente diversa.

\section{2) Proporção homem: mulher}

Neste estudo foi incluído um total de 65 pacientes, sendo 41 do sexo masculino (63\%) e 24 do sexo feminino (37\%), de acordo com a maior prevalência da DP em homens, conforme previamente mencionado. Todos os demais estudos sobre a associação entre DP e mutações da GBA também incluíram uma proporção maior de homens, em uma relação variada. No estudo de Toft et al. ${ }^{4}, 60 \%$ dos pacientes com DP eram do sexo masculino e $40 \%$ do sexo feminino; no de Clark et al. ${ }^{103}$, $62,3 \%$ dos participantes eram homens e 37,7\% mulheres. Finalmente, no estudo de AharonPeretz et al. ${ }^{3}, 55,5 \%$ da amostra analisada eram do sexo masculino, em comparação a $44,4 \%$ do sexo feminino e no de Sato et al. ${ }^{104}$ eram $59 \%$ de homens versus $41 \%$ de mulheres.

\section{3) Idade de início da DP}

Os dois pacientes com mutações da GBA neste estudo eram homens, com início precoce da DP (42 e 46 anos). A idade de início da doença abaixo da média descrita na literatura era condição necessária para integrarem o estudo. Uma vez que a DP de início mais precoce tende a ter concentração familiar, pode haver um componente genético mais marcado determinando o aparecimento da doença neste 
grupo. Esta é a razão para termos optado por incluir no estudo pacientes com DP de início mais precoce.

Lwin et al. ${ }^{75}$ ressaltaram que pelo menos 5 dos 12 indíviduos com mutações da GBA no grupo que analisaram tinham início da DP antes de 60 anos.

Aharon-Peretz et al. ${ }^{3}$ observaram que entre os pacientes com DP, aqueles que carreavam mutações da GBA eram significativamente mais jovens do que os não carreadores (média de 60 x 64,2 anos, P=0,04). O mesmo grupo de Aharon-Peretz ${ }^{78}$, em outra avaliação, observou tendência de início mais precoce da DP nos carreadores de mutações da GBA em relação aos não portadores, mas sem significância estatística neste estudo, ao contrário de publicações anteriores ${ }^{3,102}$. Toft et al. ${ }^{4}$, por sua vez, descreveram que a idade média de início da DP no seu estudo foi de 59 anos (variando de 31 a 88 anos), sendo de 56,9 anos no grupo de pacientes em que mutações da GBA foram identificadas, valores estes considerados comparáveis..

Clark et al. ${ }^{102}$ não utilizaram a idade de início da DP como critério de inclusão em seu estudo, no qual a média de idade de início da doença foi de 59 anos. No subgrupo de pacientes com DP e mutações da GBA (total de 17 pacientes), 5 tinham idade de início da doença abaixo e 12 acima de 50 anos.

Outros estudos, de forma semelhante ao aqui descrito, selecionaram para pesquisa de mutações da GBA pacientes com DP de início precoce. Foi o caso do estudo de Eblan et al. ${ }^{105}$ - DP com início entre 24 e 50 anos, com média de 36 anos e de Sato et al. ${ }^{104}$, em que foi realizada uma pré-seleção dos pacientes para idade de início precoce e/ou história familiar positiva. Neste último estudo, a idade média de início da DP foi de 41,2 anos, variando de 14 a 72 anos (70\% de todos os casos de 
DP tinham idade de início abaixo de 50 anos). Entre os pacientes com mutações da GBA, a idade de início variou de 31 a 52 anos.

\section{4) História familiar de DP}

Os dois pacientes com mutações da GBA neste estudo tinham história familiar positiva para DP (um na família materna e outro na paterna).

Em estudos anteriores, esta variável mostrou-se presente de forma inconsistente: no estudo de Toft et al. ${ }^{4}$, história familiar de DP esteve presente em apenas um dos sete pacientes com DP e mutações da GBA; Aharon-Peretz et al. ${ }^{3}$ não observaram diferença estatisticamente significativa entre pacientes com DP carreadores e não carreadores de mutações da GBA em relação à história familiar de DP em parentes de primeiro ou segundo grau; apenas um dos pacientes com DP e mutação da GBA descritos por Eblan et al. ${ }^{105}$ tinha história familiar de DP.

Por outro lado, Sato et al. ${ }^{104}$ relataram história familiar positiva para DP em $51 \%$ dos pacientes avaliados e Clark et al. ${ }^{103}$ relataram que $15,7 \%$ do total de pacientes com DP referiam história familiar positiva em parentes de primeiro grau, sendo este valor de 35,3\% no grupo de indivíduos com DP e mutações da GBA.

\section{5) Mutações da GBA}

Os dois heterozigotos identificados no presente estudo tinham a mutação L444P, sendo que o paciente 2 tinha ainda o alelo complexo E326K. A triagem da maioria dos exons da GBA nestes pacientes não mostrou outras alterações. 
Ainda deve ser elucidado se mutações específicas da GBA têm maior probabilidade do que outras de predispor os carreadores ao desenvolvimento de DP, o que não foi evidenciado nos estudos realizados até o momento.

No estudo norueguês ${ }^{4}$ foram pesquisadas as mutações N370S e L444P e, dentre os pacientes com DP, 4 tinham a mutação N370S e 3 a mutação L444P, enquanto no grupo controle 7 tinham a mutação N370S e 1 a mutação L444P. Clark et al. ${ }^{103}$ optaram por pesquisar apenas a mutação N370S, com a justificativa de que carreadores da mutação N370S podem ter DG de início tardio - normalmente nãoneurológico ou até sem quaisquer sintomas significativos - e que esta é a mutação mais comum entre judeus Ashkenazi com DG tipo 1. Foram identificados 2 homozigotos e 15 heterozigotos.

No estudo de Aharon-Peretz et al. ${ }^{3}$ foram pesquisadas 6 mutações da GBA: N370S, L444P, 84GG, IVS+1, V394L e R496H, as mais comuns entre judeus Ashkenazi, e dos 31 pacientes com DP e mutações da GBA, a distribuição por mutação foi a seguinte: 23 heterozigotos para N370S, 4 heterozigotos para 84GG, 3 homozigotos para N370S e 1 heterozigoto para R496H.

Sato et al. ${ }^{104}$ pesquisaram cinco mutações da GBA: N370S, L444P, 84GG, IVS+1 e Rec. Os 5 heterozigotos detectados dentre a população com DP avaliada carreavam as seguintes mutações: N370S - 1; L444P - 1; Rec - 3 (Rec é um alelo recombinante que compreende as alterações L444P, A456P e V460V ${ }^{105}$ ).

Em dois estudos o gene da glicocerebrosidase foi seqüenciado: no de Eblan et al. ${ }^{105}$, três alelos mutantes diferentes foram encontrados - L444P, N370S e Rec - e no de Lwin et al. ${ }^{75}$ o resultado foi de 2 homozigotos para N370S, 3 heterozigotos para N370S e um heterozigoto para cada: L444P, K198T e R329C. 
6) Quadro clínico

As manifestações clínicas da DP observadas nos pacientes com mutações da GBA neste estudo foram as esperadas para a forma idiopática da DP, com rigidez, bradicinesia e início assimétrico dos sinais motores.

Aharon-Peretz et al. descreveram em 2005 as características clínicas de 148 pacientes judeus Ashkenazi com DP idiopática, dentre os quais 40 apresentavam mutações próprias da $\mathrm{DG}^{78}$. Os carreadores de mutações da GBA não diferiam de não-carreadores em relação à idade de início da doença, sexo, história familiar de DP ou manifestações motoras no início e seguimento. Enquanto 92\% dos nãocarreadores tinham uma manifestação inicial assimétrica, foi observada assimetria em apenas $72 \%$ dos carreadores $(\mathrm{P}=0,004)$. A duração média da doença era semelhante entre os grupos. Os autores concluíram, em contraposição aos relatos de parkinsonismo em pacientes com DG, que pacientes com DP esporádica que carreiam uma mutação de DG manifestam DP típica e não diferem clinicamente no início da doença e no seguimento de pacientes com DP sem mutação.

Também no estudo de Toft et al. ${ }^{4}$, os pacientes com DP carreadores de mutações da GBA tinham um fenótipo parkinsoniano típico. Durante a progressão da doença, três tiveram declínio cognitivo significativo. Lwin et al. ${ }^{75}$ verificaram que entre os indivíduos com diagnóstico de DP em cujos cérebros se identificaram mutações da GBA, a maioria tinha história de desenvolvimento de demência ou sintomas psiquiátricos. Os pacientes do presente estudo com DP e mutações da GBA não apresentavam alterações cognitivas ou psiquiátricas.

Sato et al. ${ }^{104}$ e Clark et al. ${ }^{103}$ também descreveram início assimétrico dos sinais motores dentro do grupo de pacientes com DP (65\% na amostra de Clark et al.) e 
mutações da GBA que avaliaram. Sato et al. ${ }^{104}$ determinaram que a manifestação da doença era típica da DP em seus pacientes e Clark et al. ${ }^{103}$ especificaram os sintomas iniciais da DP relatados pelos pacientes: tremor de repouso (64\%), alteração da marcha (24\%), cãibra nos pés $(6 \%)$ e rigidez $(6 \%)$.

\section{7) Resposta à levodopa}

Outro fato que mereceu atenção foi a boa resposta à levodopa demonstrada pelos dois pacientes com DP e mutações da GBA deste estudo.

Os trabalhos iniciais que descreveram o desenvolvimento de parkinsonismo em pacientes com DG tipo 1 (portanto homozigotos para mutações da GBA) apresentavam em comum a característica da resposta insatisfatória dos pacientes ao tratamento com levodopa, contrariando o que se observa na grande maioria dos indivíduos com a forma clássica de DP. No entanto, nos estudos subseqüentes, em que pacientes com DP eram analisados para mutações da GBA, os resultados mostraram uma resposta favorável à levodopa, mesmo nos pacientes heterozigotos para mutações da GBA, estando desta forma nosso achado em consonância com a literatura.

No estudo de Toft et al. $^{4}$ os pacientes com DP e mutações da GBA tinham resposta boa ou excelente à levodopa. Resultado semelhante foi descrito por Sato et al. ${ }^{104}$, Eblan et al. ${ }^{105}$ e Aharon-Peretz et al. ${ }^{3}$, que destacaram em seu artigo que não houve diferença estatisticamente significativa entre pacientes com DP carreadores e não carreadores de mutações da GBA em relação à resposta inicial à levodopa. 
8) Outros genes relacionados à DP

Idealmente todos os pacientes avaliados neste estudo deveriam ter sido testados também para os outros genes da DP já descritos; no entanto não dispomos da possibilidade de realizar tal procedimento de rotina. Alguns dos pacientes que integraram o estudo participaram também de outro projeto de pós-graduação desenvolvido no ambulatório de Distúrbios do Movimento, que visava pesquisar as mutações do tipo PARK. Para serem incluídos neste outro trabalho, os pacientes deveriam ter idade de início da doença inferior a 40 anos e/ou história familiar positiva para DP. Dentre os pacientes testados para mutações da GBA, em um (número 29 da Tabela 5) foi detectada a presença de mutação do gene de parkin (PARK2) e em outro (número 48 da Tabela 5), mutação do gene LRRK2 $\left(\right.$ PARK8) ${ }^{116,117,118}$. Ambos não apresentavam mutações da GBA.

Dentre os estudos já publicados acerca da associação DP e mutações da GBA, apenas dois fazem referência à pesquisa de outros genes relacionados à DP. Toft et al. ${ }^{4}$ mencionaram o fato de que "pacientes com uma causa genética conhecida de parkinsonismo não foram incluídos”, sem maiores especificações. Já Sato et al. ${ }^{104}$ relataram que a presença de mutações nos genes de parkin e DJ-1 foi excluída em todos os casos de DP avaliados.

Um fato particularmente interessante quanto à identificação da maior susceptibilidade à DP entre carreadores de mutações da GBA (mesmo em um único alelo) é que até então a heterozigose para a DG seria supostamente assintomática. A própria DG tipo 1 caracteriza-se por uma heterogeneidade clínica, que pode permitir que muitos pacientes permaneçam virtualmente assintomáticos, sendo diagnosticados 
durante avaliação para distúrbio não relacionado ou por rastreamento familiar de um parente sintomático $^{79,82}$. Perez-Calvo et al., em 2005, em um inquérito nacional na Espanha, analisaram pacientes com DG e carreadores das mutações correspondentes não afetados por DG com o objetivo de avaliar o risco deste grupo de apresentar outras doenças quando comparados a pacientes saudáveis não carreadores das mutações ${ }^{119}$. Os autores concluíram que, como um grupo, os pacientes com DG tinham maior risco de desenvolver outras doenças como demência, DP, acidente cerebrovascular e infarto agudo do miocárdio do que indivíduos saudáveis e do que carreadores das mutações correspondentes. Já o status de carreador por si só, neste estudo, não pareceu aumentar o risco de outras doenças.

Atualmente, após a publicação dos estudos associando mutações da GBA e DP, acredita-se que os heterozigotos para mutações causadoras de DG sejam mais susceptíveis, quando expostos a outros fatores, a deflagrar o processo neurodegenerativo que culmina com a DP. Além dos exemplos de literatura de pacientes com DG que desenvolveram parkinsonismo, foi-nos possível avaliar no ambulatório dois pacientes que preenchiam estas características, conforme descrito na introdução.

\subsection{Da associação DP x DG - Fisiopatologia}

A natureza da associação entre DG e DP ainda não foi elucidada. Especula-se que o mecanismo envolvido no desenvolvimento da DP em pacientes carreadores de mutações da GBA esteja relacionado ao processamento defeituoso de proteínas tóxicas, agravado pela redução relativa na atividade de glicocerebrosidase e o conseqüente acúmulo de glicocerebrosídeos ${ }^{3}$. Estudos indicam que o acúmulo de 
glicocerebrosídeos induz apoptose em neurônios em cultura e que neurônios com níveis elevados de glicocerebrosídeos mostram sensibilidade aumentada a agentes que induzem morte celular. Células mesencefálicas, incluindo neurônios dopaminérgicos, sofrem apoptose após lesão induzida por ceramida ${ }^{120}$, sugerindo que a disfunção do metabolismo dos esfingolipídeos possa induzir a morte de células dopaminérgicas ${ }^{3}$.

Em 2004, Sidransky et al. estudaram a patologia cerebral de 14 pacientes com $\mathrm{DG}^{61}$. Nesta amostra, quatro tinham DG tipo 1 e parkinsonismo e seu estudo histopatológico evidenciou numerosas inclusões positivas para sinucleína, semelhantes aos corpos de Lewy encontrados na DP, sugerindo um mecanismo citotóxico comum ligando atividade reduzida da glicocerebrosidase, citotoxicidade neuronal e formação de corpos de Lewy na DG.

Feany, em artigo publicado em 2004, sugeriu que a ligação da alfa-sinucleína a membranas lipídicas protegeria a proteína do dobramento inadequado e agregação ${ }^{124}$. Mutações da GBA alterariam a composição lipídica da membrana, favorecendo o acúmulo de alfa-sinucleína no citossol e sua conseqüente agregação nos corpos de Lewy ${ }^{122}$. Já se mostrou que a afinidade da alfa-sinucleína por superfícies lipídicas é sensível à composição da mesma ${ }^{123}$.

Aharon-Peretz et al. posicionaram-se de acordo com a hipótese de Feany, enfatizando também, em publicação de 2005, que a forma funcional da alfasinucleína é um estado ligado a lipídeos e envolve a interação entre membranas lipídicas. O acúmulo de glicocerebrosídeo poderia perturbar a afinidade da alfasinucleína por superfícies lipídicas. Uma possível interseção DP-DG envolveria um ganho tóxico de função relacionado ao acúmulo de alfa-sinucleína aberrante, 
degradação imprópria de alfa-sinucleína, ou uma combinação de ambos os processos. Além disso, neurônios com nível elevado de glicocerebrosídeos, secundário à deficiência de glicocerebrosidase, podem ter sensibilidade aumentada a agentes que induzem morte celular através da mobilização de cálcio das reservas intracelulares ${ }^{3}$.

Shlossmaker et al. também exploraram a possibilidade de interação entre glicocerebrosídeos e alfa-sinucleína, após a descoberta de que uma variante da alfasinucleína no cérebro humano carreava ácido siálico e $\mathrm{N}$-acetilgalactosamina ${ }^{121}$. Foi observada, inesperadamente, uma forte ligação da alfa-sinucleína a glicoesfingolipídeos derivados do cérebro humano que continham glicosilceramida como sua estrutura central. Há evidências de que o processamento da alfa-sinucleína ocorra também dentro dos lisossomos, o local de metabolismo dos glicoesfingolipídeos. A observação da ligação direta da alfa-sinucleína a glicoesfingolipídeos contendo glicocerebrosídeo fornece uma possível ligação bioquímica entre a atividade enzimática da glicocerebrosidase e a sinucleinopatia associada à DP.

Vila et al. comentaram em estudo de 2004 que a alfa-sinucleína, em fungos, se liga preferencialmente a membranas plasmáticas e que esta interação, que é mediada por alterações de conformação da proteína, parece ser crucial para várias de suas funções fisiológicas. A alfa-sinucleína ligada à membrana parece estar em equilíbrio dinâmico com a citossólica, que, quando acumulada, pode tornar a dopamina endógena tóxica e agir na formação de inclusões citossólicas ${ }^{7}$.

Halperin et al. sugeriram que a alteração bioquímica (atividade enzimática minimamente reduzida ou depósito de glicolipídeo um pouco aumentado) em carreadores de mutações da DG poderia desencadear DP em pacientes predispostos 
por outros fatores, genéticos ou não ${ }^{125}$. Os autores defendem a hipótese de que uma mutação na GBA, mesmo em uma cópia, é um fator de susceptibilidade ou mediador não-genético no desenvolvimento de DP em um subgrupo de indivíduos. Isso poderia se dever a uma perda de função, onde a atividade enzimática reduzida levaria a um aumento focal de glicosilceramida em regiões cerebrais específicas. $\mathrm{O}$ efeito de um defeito bioquímico possivelmente existente em neurônios desde o nascimento seria uma nova hipótese para explicar o advento de DP em alguns indivíduos.

\subsection{Das descobertas genéticas na DP}

Este trabalho deve ser compreendido dentro de um contexto maior em que a Genética vem modificando a concepção da DP.

Atualmente os critérios diagnósticos mais utilizados para a DP idiopática são os do United Kingdom Parkinson's Disease Society Brain Bank - Banco de Cérebro de Londres (Anexo A), utilizados no presente estudo, que requerem a presença de bradicinesia e pelo menos mais um dos seguintes: rigidez muscular, tremor de repouso (geralmente de 4 a 6 Hertz) e instabilidade postural não causada por disfunção primária visual, cerebelar ou proprioceptiva, além da exclusão de uma série de fatores ${ }^{106,107,108}$. Considerando-se que outras doenças, como paralisia supranuclear progressiva e atrofia de múltiplos sistemas, entre outras, podem ser de difícil diferenciação de um quadro de DP, torna-se importante a atenção aos critérios vigentes, para que se mantenha uma boa acurácia diagnóstica. O início assimétrico dos sintomas e uma boa resposta ao tratamento com levodopa favorecem o diagnóstico de DP e são as características mais importantes para distinguir a DP de outros diagnósticos ${ }^{27}$. 
Um diagnóstico clínico fidedigno de DP era possível em $76 \%$ dos casos no início da década de 90, conforme revelado por um estudo clínico-patológico de um importante grupo de Distúrbios do Movimento de Londres ${ }^{126}$. Uma reavaliação pelo mesmo grupo quase 10 anos após mostrou que esse valor havia aumentado para $90 \%$ de acurácia diagnóstica para DP idiopática ${ }^{127}$, o que é considerado bastante satisfatório, ainda que não infalível.

Os novos avanços relacionados às descobertas genéticas na DP trouxeram mudanças significativas na compreensão e até mesmo na definição vigente da mesma, de modo que apesar de o diagnóstico de certeza da DP permanecer sendo o histopatológico, caracterizado por perda neuronal, gliose e corpos de Lewy, publicações recentes questionam tal "padrão-ouro", a partir do achado de casos familiares de DP sem a histopatologia típica ${ }^{128}$.

A identificação das formas genéticas da DP e a descrição das diversas faces da doença trouxeram à tona o fato de a DP ser uma condição clínica e patologicamente heterogênea, o que deve ser levado em conta considerando-se que na prática o diagnóstico da doença é essencialmente clínico. Muitos autores têm inclusive sugerido a substituição da denominação “doença de Parkinson” para "síndrome parkinsoniana", de modo a unificar os diferentes subgrupos que levam a uma via final comum - degeneração seletiva dos neurônios dopaminérgicos ${ }^{13}$.

Outra condição genética recentemente descrita que pode ocasionar um quadro clínico de parkinsonismo, simulando DP, é a síndrome de tremor/ataxia associada ao X frágil (FXTAS). Esta é uma doença neurológica decorrente da expansão - de 55 a 200 repetições - no gene FMR1 (fragile site mental retardation 1, também responsável, quando na presença de maior número de repetições, pela síndrome do $\mathrm{X}$ 
frágil, a principal causa hereditária de retardo mental). Os sinais cardinais da DP são comuns na síndrome FXTAS, sendo tremor e rigidez os mais proeminentes ${ }^{129}$.

A crescente identificação de genes associados à DP também levanta uma questão polêmica, que possivelmente se tornará habitual em um futuro próximo, referente à indicação de testar ou não testar pacientes com suspeita de DP de etiologia genética para as mutações já identificadas. Atualmente encontram-se disponíveis no mercado testes comerciais para as mutações nos genes de parkin e alfa-sinucleína ${ }^{33}$, mas não são recomendados de rotina na prática clínica, já que a detecção de um dos genes com a mutação não propicia alteração na abordagem do paciente, isto é, o tratamento permanece o mesmo, talvez com o acréscimo de um estigma para o paciente. Sem um tratamento preventivo disponível para a DP, o teste genético não oferece benefícios médicos diretos aos pacientes ou seus familiares ${ }^{51}$.

É provável que em breve encontre-se disponível uma gama maior de testes genéticos para a DP, mas antes de solicitar o exame, é fundamental que o médico avalie as vantagens, desvantagens e limitações do teste genético pré-sintomático da DP. Recomenda-se que ele só seja oferecido em famílias nas quais um membro afetado tenha sido previamente identificado como portador de uma mutação ou se existe uma alta probabilidade de que a DP herdada na família seja resultante de uma mutação genética conhecida ${ }^{33}$. Em todo o caso, se for decidido proceder ao teste, por sugestão do médico ou insistência do paciente, deve-se orientar um aconselhamento genético prévio em centros especializados e o paciente, ciente dos prós e dos contras do exame, deve assinar um termo de consentimento.

Outra desvantagem dos testes genéticos para DP é que, além do alto custo, eles freqüentemente geram resultados inconclusivos ${ }^{35}$. Por outro lado, estes testes têm o 
potencial de refinar diagnósticos clínicos e identificar pacientes com maior chance de se beneficiar de intervenções específicas (o que possivelmente será útil quando estiverem disponíveis mais opções terapêuticas). Do ponto de vista científico, estes testes permitem que carreadores assintomáticos de mutações que predispõem à DP possam ser identificados, gerando uma fonte valiosa para pesquisa sobre exposições ambientais ${ }^{13}$ e estratégias de neuroproteção ${ }^{35}$.

Klein afirma em publicação de 2006 que "os achados genéticos têm permitido avanços importantes na compreensão da fisiopatologia da DP, porém trazem consigo novos desafios, como a identificação de fatores de susceptibilidade genética e definição do espectro clínico das formas monogênicas"35.

\subsection{O futuro}

Em estudo recente, Goker-Alpan et al. (do grupo de Sidransky, do National Institute of Health) demonstraram a presença de mutações da GBA em número significativo de pacientes com demência por corpos de Lewy ${ }^{130}$. Esta condição, caracterizada por parkinsonismo associado a quadro demencial instalado no primeiro ano de evolução da doença, é considerada por muitos autores como parte do espectro patológico da DP, em que os corpos de Lewy ocorrem preferencialmente em regiões corticais, justificando a diferença clínica entre as doenças. No estudo, os autores seqüenciaram o gene da glicocerebrosidase em amostras de cérebros de pacientes com diagnóstico de sinucleinopatias: 35 com demência por corpos de Lewy, 29 com DP e 12 com atrofia de múltiplos sistemas. Nove dos cérebros estudados (12\%) apresentavam mutações da GBA em heterozigose, a grande maioria entre os pacientes com demência por corpos de Lewy, nos quais a taxa de mutação foi de 
23\%. Apenas em 1 de 28 cérebros de indivíduos com DP foi detectada mutação da GBA e em nenhum no grupo com atrofia de múltiplos sistemas. O achado de mutações da GBA como fator predisponente para demência por corpos de Lewy favorece a hipótese de um continuum entre esta entidade e a DP, possivelmente conectadas por uma via fisiopatológica comum. Novos estudos poderão reforçar este conceito. Os autores sugerem que este estudo implica a contribuição da glicocerebrosidase mutante em diferentes doenças caracterizadas por inclusões neuronais e que ela serve como exemplo de uma enzima que, quando submetida a uma mutação, pode ter um papel inesperado em relação à sua função primária e contribuir para a patogênese de condições complexas, como a DP e a demência por corpos de Lewy.

\subsection{Comentários finais}

Em pacientes com parkinsonismo idiopático de instalação precoce com resposta precária ao tratamento específico, o diagnóstico de DG deve ser levado em consideração, mesmo na ausência de manifestações típicas desta doença ${ }^{131}$, porém devido à baixa prevalência da DG, não deve ser considerada uma investigação mais invasiva para a doença na abordagem inicial do paciente.

Nos casos em que os diagnósticos concomitantes de DP e DG são estabelecidos, deve-se estar ciente de que este grupo de pacientes não obtêm melhora do quadro parkinsoniano com a terapia de reposição enzimática, específica para a DG.

Apesar da associação descrita, a vasta maioria dos pacientes com DG e portadores das mutações correspondentes nunca desenvolve sinais clínicos de 
parkinsonismo, assim como a maioria dos pacientes com DP não são portadores de mutações da GBA ${ }^{132}$. Certamente outros fatores, genéticos e ambientais, também devem interferir no processo etiopatogênico. A mutação da GBA poderia ser um segundo deflagrador em pacientes com predisposição genética a parkinsonismo ${ }^{61}$.

A importância de se compreender os mecanismos fisiopatológicos da DP a partir de dados genéticos é exemplificada pelo achado de que a presença de mutações no gene da alfa-sinucleína em pacientes com DP levou à descoberta da alfasinucleína como o principal componente dos corpos de Lewy, o marcador patológico da DP. Além disso, a identificação de parkin como uma ubiquitina E3 ligase ${ }^{45}$ trouxe $^{2}$ para o cenário o sistema ubiquitina-proteassomo. As evidências sugerem que o mesmo desempenha um papel de destaque na fisiopatologia da DP, à medida em que de sua disfunção resulta um processamento defeituoso das proteínas intracelulares, favorecendo sua agregação e depósito. As mutações da GBA funcionariam como mais uma peça deste quebra-cabeça.

O mecanismo biológico subjacente à associação DP-DG ainda deve ser elucidado, apesar de já terem sido aventadas algumas hipóteses. A importância de desvendar a razão desta associação está relacionada não apenas a uma melhor compreensão das bases etiológicas de ambas as doenças, mas também com a possibilidade de desenvolvimento de terapias mais específicas para DP neste grupo de pacientes no futuro.

No momento, devido aos conhecimentos ainda limitados na área, não se recomenda de rotina o teste para mutações da GBA em pacientes com DP.

Este é o primeiro estudo a investigar a associação entre mutações da GBA e DP na população brasileira e o sexto a fazê-lo em âmbito mundial (considerando-se 
apenas os artigos publicados). Novos estudos são necessários para tentar esclarecer a natureza da associação entre DP e DG. Apesar de já existirem hipóteses a este respeito, uma maior compreensão desta associação certamente contribuirá para um melhor entendimento da fisiopatologia da DP como um todo, ainda obscura na sua plenitude.

Mutações da GBA, mesmo em indivíduos heterozigotos, podem ser um fator de risco hereditário para o desenvolvimento de DP. Este achado, previamente descrito para outras populações, através deste trabalho mostra ser pertinente também para a população brasileira. 


\section{CONCLUSÕES}

1) Pesquisando-se as principais mutações da GBA (N370S, L444P e G377S) em 65 pacientes com DP em uma população brasileira, foi encontrada uma prevalência de aproximadamente $3 \%$.

2) Comparando-se este resultado com a análise de 267 controles emparelhados para idade e sexo, dos quais nenhum era portador das mutações da GBA avaliadas, obteve-se uma associação estatisticamente significativa $(\mathrm{P}=0,0379$, teste exato de Fisher).

3)A prevalência de mutações de GBA em pacientes brasileiros com DP foi menor do que previamente relatado na literatura, porém maior do que o esperado para a população geral, sugerindo uma provável associação entre as duas entidades nosológicas na nossa população.

4)Não foi possível identificar nos pacientes com DP portadores de mutações da GBA características que permitissem diferenciá-los clinicamente de pacientes sem a mutação. 


\section{ANEXOS}

Anexo A: Critérios diagnósticos de DP segundo o Banco de Cérebro de Londres

\section{Critérios Clínicos Diagnósticos do Banco de Cérebro da Sociedade de Doença de Parkinson do Reino Unido}

(UK Parkinson 's Disease Society Brain Bank Clinical Diagnostic Criteria)

\section{†Etapa 1: Diagnóstico de síndrome parkinsoniana}

Bradicinesia e pelo menos um dos seguintes: rigidez muscular, tremor de repouso de 4 a 6 $\mathrm{Hz}$, instabilidade postural não causada por disfunção primária visual, vestibular, cerebelar ou proprioceptiva.

\section{† Etapa 2:Critérios de Exclusão para Doença de Parkinson}

História de acidente cerebrovascular de repetição com progressão em degrau das características parkinsonianas; história de traumatismo craniano de repetição; história de encefalite definida; crises oculógiras; tratamento com neurolépticos no início dos sintomas; mais de um parente afetado; remissão sustentada; características estritamente unilaterais após 3 anos; paralisia supranuclear do olhar; sinais cerebelares; envolvimento autonômico precoce grave, demência precoce grave com distúrbios de memória, linguagem e praxia; sinal de Babinski; presença de tumor cerebral ou hidrocefalia comunicante na tomografia computadorizada; resposta negativa a altas doses de levodopa (excluindo-se mal absorção); exposição a MPTP.

\section{\Etapa 3:Critérios Prospectivos Positivos de Suporte para Doença de Parkinson (são} requeridos três ou mais para o diagnóstico de doença de Parkinson definida)

Início unilateral, tremor de repouso presente, doença progressiva, assimetria persistente afetando mais o lado de início, resposta excelente (70 a 100\%) à levodopa, coréia grave induzida por levodopa, resposta à levodopa por 5 ou mais anos, curso clínico de 10 anos ou mais. 
Anexo B: Termo de consentimento

\section{Termo de Consentimento Livre e Esclarecido}

Estudo: Mutações da glicocerebrosidase em pacientes com doença de Parkinson Você está sendo convidado a participar do projeto de pesquisa "Mutações da glicocerebrosidase em pacientes com doença de Parkinson". Este documento contém as informações necessárias sobre a pesquisa em questão. Sua participação neste estudo é importante para nós, mas se optar por desistir em qualquer momento, isso não causará prejuízo ao seu tratamento e acompanhamento no Setor de Distúrbios do Movimento do HCFMUSP.

$\mathrm{Eu}$, portador da cédula de identidade $\mathrm{n}^{\circ}$ inscrito no CPF $n^{\circ}$ nascido em

________ abaixo assinado (a), concordo de livre e espontânea vontade em participar como voluntário (a) do estudo Mutações da glicocerebrosidase em pacientes com doença de Parkinson. Declaro que obtive todas as informações necessárias, assim como todos os eventuais esclarecimentos quanto às dúvidas por mim apresentadas.

Estou ciente de que:

- O objetivo do estudo é identificar, dentre os pacientes com síndrome parkinsoniana de início precoce, aqueles portadores da mutação para Doença de Gaucher;

-Será feita coleta de material da mucosa jugal através do uso de uma haste flexível;

-Esta coleta será realizada para este estudo e não terá influência no meu tratamento, não envolve riscos para a saúde e não é terapêutica;

- A participação nesta pesquisa não tem objetivo de me submeter a um tratamento e não me trará qualquer ônus em relação aos procedimentos médicos envolvidos;

- Tenho o direito de desistir da participação no estudo em qualquer momento;

- A desistência não terá implicações na minha saúde ou no meu tratamento;

- Os resultados desta pesquisa serão mantidos em sigilo, mas concordo que sejam divulgados em publicações científicas, desde que meus dados pessoais não sejam mencionados;

- Caso eu desejar, poderei tomar conhecimento dos resultados ao final da pesquisa:

( ) Desejo conhecer os resultados desta pesquisa

( ) Não desejo conhecer os resultados desta pesquisa

São Paulo, de de 200

Assinatura do paciente: 
Anexo C: Aprovação do projeto pelo Comitê de Ética

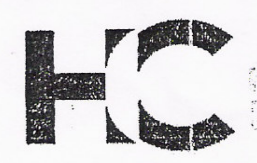

DIRETORIA CLÍNICA

Comissăa de Ética para Análise de Projetos de Pesquisa

\section{APROVACÃO}

A Comissão de Ética para Análise de Projetos de Pesquisa - CAPPesq da Diretoria Clínica do Hospital das Clínicas e da Faculdade de Medicina da Universidade de São Paulo, em sessão de 11.08.04, APROVOU o Protocolo de Pesquisa $n^{\circ} 359 / 04$, intitulado: "Síndrome Parkinsoniana como manifestação da doença de Gaucher" apresentado pelo Departamento de NEUROLOGIA, inclusive o Termo de Consentimento Livre e Esclarecido.

Pesquisador(a) Responsável: Prof. Dr. Egberto Reis Barbosa Pesquisador(a) Executante: Dra. Mariana Spitz

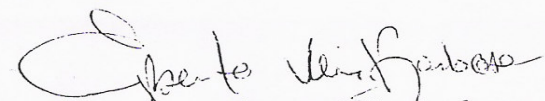

CAPPesq, 11 de Agosto de 2004.

Prof. Dr. Egberto Reis Barbosa Orientador

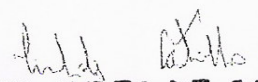

PROF. DR. EUCLIDES AYRES DE CASTILHO

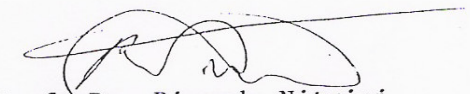

Presidente da Comissão de Ética para Análise de Projetos de Pesquisa

Prof. Dr. Ricardo Nitrini

Coordenador

OBSERVAÇÃO: Cabe ao pesquisador elaborar e apresentar à CAPPesq, os relatórios parciais e final sobre a pesquisa (Resolução do Conselho Nacional de Saúde $n^{\circ} 196$, de 10.10.1996, inciso IX.2, letra " $c$ ") 
Anexo D: Explicando a Genética (referências 112,113,114)

- Pseudogene: seqüência que se parece muito com um gene funcional conhecido, em outro locus dentro do genoma, que é não-funcional como conseqüência de mutações que impedem sua transcrição e/ou translação.

- Alelo: as duas cópias de um gene autossômico ou locus nos cromossomos materno e paterno são alelos. Se os dois alelos são idênticos, o indivíduo é homozigoto naquele locus.

- Eletroforese: método para analisar o tamanho dos fragmentos de DNA. Na presença de um campo elétrico, fragmentos maiores de DNA se movem através do gel mais lentamente que os menores, produzindo bandas no gel.

- Enzimas de restrição (ou endonucleases de restrição): classe de enzimas, geralmente isoladas de bactérias, capazes de reconhecer e cortar sequiências específicas do DNA.

- PCR (polymerase chain reaction): técnica utilizada para replicar um fragmento específico de DNA in vitro. Adicionam-se primers, que iniciam a cópia de cada banda do DNA, junto com nucleotídeos e uma enzima denominada Taq polimerase. Cicla-se a temperatura, fazendo com que o DNA alvo seja repetidamente desnaturado e copiado. Uma única cópia de DNA, mesmo se misturada com outro DNA indesejável, pode ser amplificada para se obter bilhões de réplicas.

- Polimorfismo de restrição de fragmento por comprimento: ensaio que utiliza a propriedade de reconhecimento de sequiências de enzimas de restrição para demonstrar variações ou polimorfismos na seqüência de DNA de duas amostras. O DNA genômico ou o DNA produzido a partir de uma reação de PCR é digerido por uma enzima de restrição e os fragmentos são analisados por eletroforese com gel, seguida de visualização por bandas. Alterações na sequiência do DNA podem resultar em alteração do reconhecimento da sequiência da enzima, que são refletidas em mudança no tamanho da banda visualizada no gel. 
Anexo E: Formulário para envio de sangue para dosagem de glicocerebrosidase.

\section{HOSPITAL DE CLÍNICAS DE PORTO ALEGRE SERVIÇO DE GENÉTICA MÉDICA}

\section{LABORATÓRIO DE ERROS INATOS DO METABOLISMO}

Rua Ramiro Barcelos, 2350 - CEP $90035-903$ - Porto Alegre - RS - fone (51) 33168011 - fax (51)3316 8010 e-mail: jcoelho@hcpa.ufrgs.br

PROGRAMA DE INVESTIGAÇÃO PARA GAUCHER, NIEMANN-PICK, FABRY, MPS I E POMPE

FORMULÁRIO DE SOLICITAÇÃO (preenchimento obrigatório / letra legivel)

n'SGM:

\begin{tabular}{|l|l|}
\hline \multicolumn{1}{c|}{ PACIENTE } \\
Iniciais: & Número do pront. inst. origem: \\
Responsável: & Sexo: \\
Data de Nascimento:
\end{tabular}

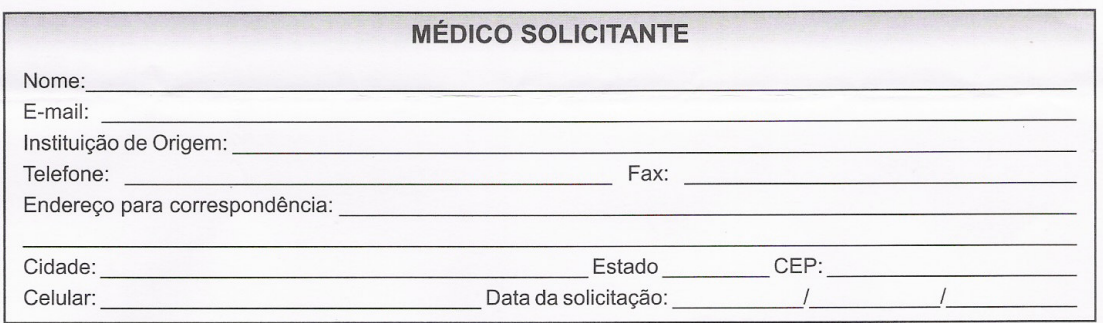

\begin{tabular}{l}
\hline Amostras enviadas \\
( ) urina \\
( ) plasma \\
( ) sangue heparinizado \\
( ) sangue com EDTA \\
( ) biópsia de pele \\
( ) papel filtro \\
( ) \\
\hline
\end{tabular}

Solicito diagnóstico enzimático para:
( ) Fabry
( ) Pompe
( ) MPS 1
( ) Gaucher
( ) Niemann-Pick do tipo B
( ) Outra situação (especificar)

( )

Em caso de diagnóstico positivo, genotipar?

$\square \operatorname{Sim} \square$ Não 
Anexo F: Resultado da dosagem de atividade da glicocerebrosidase dos pacientes $1 \mathrm{e}$ 2 , respectivamente.

\section{SERVICO DE GENETICA MEDICA HOSPITAL DE CLINICAS DEPORTO ALEGRE}

LABORATÓRIO DE REFERÊNCIA DE ERROS INATOS DO METABOLISMO

Rua Ramiro Barcelos, 2350 - CEP 90035 -903 - Porto Alegre - RS - fone (51) 21018011 - fax (51)2101 8010 e-mail: icoelho@hcpa.ufrgs.br

\section{PROGRAMA DE INVESTIGACÃO PARA} DOENÇA DE GAUCHER

No. SGM: 215

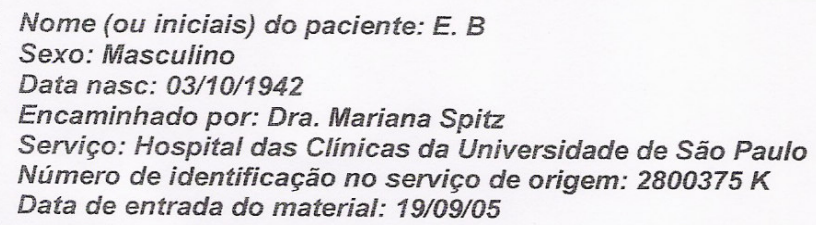

Resultado: $116 \mathrm{nmol} / \mathrm{h} / \mathrm{mL}$

Valores de referência: $\quad$ Normal $=\quad 8,8$ a $132 \mathrm{nmol} / \mathrm{h} / \mathrm{mL}$

Observação: Sugiro o envio de biópsia de pele para análise enzimática em fibroblastos. 


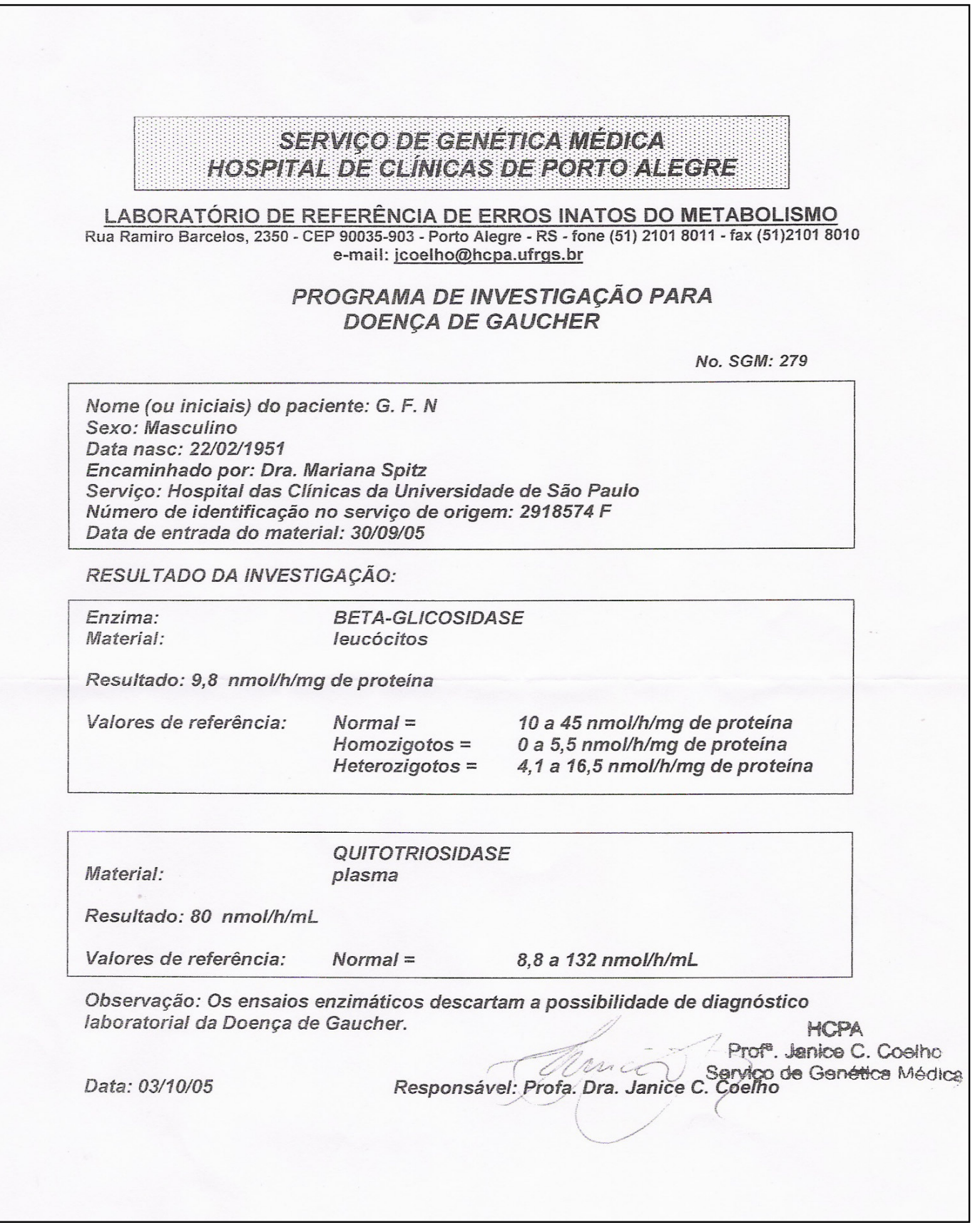




\section{REFERÊNCIAS}

1. Tolosa E, Martí MJ, Valldeoriola F, Molinuevo JL. History of levodopa and dopamine agonists in Parkinson's disease treatment. Neurology 1998;50(Suppl 6):S2-10.

2. Gwinn-Hardy K. Genetics of Parkinsonism. Mov Disord 2002;17:645-56.

3. Aharon-Peretz J, Rosenbaum H, Geshoni-Baruch R. Mutations in the glucocerebrosidase gene and Parkinson's disease in Ashkenazi jews. $N$ Engl J Med 2004;351:1972-7.

4. Toft M, Pielsticker L, Ross A, Aasly JO, Farrer MJ. Glucocerebrosidase gene mutations and Parkinson disease in the Norwegian population. Neurology 2006;66:415-7.

5. Teive H. O papel de Charcot na doença de Parkinson. Arq Neuropsiquiatr 1998;56:141-5.

6. Parkinson J. An essay on the shaking palsy. J Neuropsychiatry Clin Neurosci 2002;14:223-36. (originalmente publicado como uma monografia por Sherwood, Neely and Jones, Londres, 1817).

7. Vila M, Przedborski. Genetic clues to the pathogenesis of Parkinson's disease. Nat Med 2004;10(Suppl):S58-S62.

8. Dauer W, Przedborski S. Parkinson's disease: mechanisms and models. Neuron 2003;39:889-909.

9. Van Den Eeden SK, Tanner CM, Bernstein AL, et al. Incidence of Parkinson`s disease: variation by age, gender, and race/ethnicity. Am J Epidemiol 2003;157:1015-22.

10. Dawson TM, Dawson VL. Neuroprotective and neurorestorative strategies for Parkinson's disease. Nat Neurosci 2002;5(Suppl):1058-61.

11. Tolosa E, Wenning G, Poewe W. The diagnosis of Parkinson's disease. Lancet Neurol 2006;5:75-86.

12. Goedert M. Alpha-synuclein and neurodegenerative diseases. Nat Rev Neurosci 2001;2:492-5.

13. Farrer MJ. Genetics of Parkinson disease: paradigm shifts and future prospects. Nature 2006;7:306-18.

14. Miyasaki JM, Shannon K, Voon V, et al. Practice parameter: evaluation and treatment of depression, psychosis, and dementia in Parkinson's disease (an evidence-based review). Neurology 2006;66:996-1002.

15. Gelb DJ, Oliver E, Gilman S. Diagnostic criteria for Parkinson disease. Arch Neurol 1999;56:33-9. 
16. Suchowersky O, Reich S, Perelmutter J, Zesiewicz T, Gronseth G, Weiner WJ. Practice Parameter: Diagnosis and prognosis of new onset Parkinson disease (an evidence-based review): report of the Quality Standards Subcommittee of the American Academy of Neurology. Neurology. 2006;66:968-75.

17. Pahwa R, Factor SA, Lyons KE, et al. Practice Parameter: treatment of Parkinson disease with motor fluctuations and dyskinesia (an evidence-based review): report of the Quality Standards Subcommittee of the American Academy of Neurology. Neurology 2006;66:983-95.

18. Stocchi F. Optimising levodopa therapy for the management of Parkinson's disease. J Neurol 2005;252(Suppl 4):43-8.

19. Ropper AH, Brown RH. Adams and Victor's Principles of Neurology. $8^{\text {th }}$ edition New York: McGraw-Hill; 2005.

20. Barbosa ER, Limongi JC, Cummings JL. Parkinson's disease. Psychiatr Clin North Am 1997;20:769-90.

21. Barbosa MT, Caramelli P, Maia DP, et al. Parkinsonism and Parkinson's disease in the elderly: A community-based survey in Brazil (the Bambui study). Mov Disord 2006;21:800-8.

22. Jankovic J. Searching for a relationship between manganese and welding and Parkinson's disease. Neurology 2005;64:2021-8.

23. Schrag A, Schott M. Epidemiological, clinical, and genetic characteristics of early-onset parkinsonism. Lancet Neurol 2006;5:355-63.

24. Findley L, Aujla M, Bain PG, et al. Direct economic impact of Parkinson's disease: a research survey in the United Kingdom. Mov Disord 2003;18:1139-45.

25. Schrag A, Hovris A, Morley D, Quinn N, Jahanshahi M. Young- versus older-onset Parkinson's disease: impact of disease and psychosocial consequences. Mov Disord 2003;11:1250-6.

26. Baldereschi M, Dicarlo A, Vanni P, et al. and the Italian longitudinal study on aging working group. Life-style related risk factors for Parkinson's disease: a population study. Acta Neurol Scand 2003;108:234-44.

27. deLau LM, Breteler MB. Epidemiology of Parkinson's disease. Lancet Neurol 2006;5:525-35.

28. Twelves D, Perkins KSM, Counsell C. Systematic review of incidence studies of Parkinson's disease. Mov Disord 2003;18:19-31.

29. Schrag A, Ben-Shlomo Y, Quinn NP. Cross sectional prevalence survey of idiopathic Parkinson`s disease and parkinsonism in London. BMJ 
2000;321:21-2.

30. Sherer TB, Betarbet R, Greenamyre JT. Enviroment, mithocondria, and Parkinson's disease. The Neuroscientist 2002;8:192-6.

31. Healy DG, Abou-Sleiman PM, Wood NW. PINK, PANK, or PARK? A clinicians'guide to familial parkinsonism. Lancet Neurol 2004;3:652-62.

32. Firestonde JA, Smith-Weller T, Franklin G, Swanson P, Longstreth WT, Checkoway H. Pesticides and risk of Parkinson's disease - a populationbased case-control study. Arch Neurol 2005;62:91-4.

33. McInerney-Leo A, Hadley DW, Gwinn-Hardy K, Hardy J. Genetic testing in parkinson's disease. Mov Disord 2005;20:1-10.

34. Wirdefeldt K, Gatz M, Schaning M, Pedersen NL. No evidence for heritability of Parkinson's disease in Swedish twins. Neurology 2004;63:30511.

35. Klein C. Implications of genetics on the diagnosis and care of patients with Parkinson's disease. Arch Neurol 2006;63:328-34.

36. Warner TT, Schapira AH. Genetic and environmental factors in the cause of Parkinson's disease. Ann Neurol, 2003;53(Suppl 3):S16-23; discussion S23-5.

37. Polymeropoulos H, Lavedan C, Leroy E, et al. Mutation in the alphasynuclein gene identified in families with Parkinson's disease. Science 1997;276:2045-7.

38. Spillantini MG, Schmidt ML, Lee VMY, Trojanowski JQ, Jakes R, Goedert M. $\alpha$-Synuclein in Lewy bodies. Nature 1997;388:839-40.

39. Spillantini MG, Crowther RA, Jakes R, Hasegawa M, Goedert M. $\alpha$ Synuclein in filamentous inclusions of Lewy bodies from Parkinson's disease and dementia with Lewy bodies. Proc Natl Acad Sci 1998;95:6469-73.

40. Singleton A. What does PINK1 mean for Parkinson diseases? Neurology 2004;63:1350-1.

41. Zimprich A, Biskup S, Leitner $\mathrm{P}$, et al. Mutations in LRRK2 cause autosomal-dominant parkinsonism with pleomorphic pathology. Neuron 2004;44:601-7.

42. Lee MK, Stirling W, Xu Y, et al. Human $\alpha$-synuclein-harboring familial Parkinson's disease-linked Ala-53 $\rightarrow$ Thr mutation causes neurodegenerative disease with $\alpha$-synuclein aggregation in transgenic mice. Proc Nat Acad Science 2002;99:8968-73.

43. Shapira AHV. Etiology of Parkinson's disease. Neurology 2006;66(Suppl 4):S10-S23.

44. Kitada T, Asakawa S, Hattori N, et al. Mutations in the parkin gene cause 
autosomal recessive juvenile parkinsonism. Nature 1998;392:605-8.

45. Shimura H, Hattori N, Kubo S, et al. Familial Parkinson disease gene product, parkin, is a ubiquitin-protein ligase. Nat Genet 2000;25:302-5.

46. McNaught KSP, Jackson T, JnoBaptiste R, Kapustin A, Olanow W. Proteasomal dysfunction in sporadic Parkinson's disease. Neurology 2006;66(Suppl 4):S37-S49.

47. Greenamyre JT, Hastings TG. Parkinson's - divergent causes, convergent mechanisms. Science 2004;304:1120-2.

48. Valente EM, Abou-Sleiman PM, Caputo V, et al. Hereditary early-onset Parkinson's disease caused by mutations in PINK-1. Science 2004;304:115860.

49. Bonifati V, Rizzu P, van Baren $M$, et al. Mutations in the DJ-1 gene associated with autosomal recessive early-onset parkinsonism. Science 2003;299:256-9.

50. Bandmann O. DJ-1 - The second gene for early onset Parkinson disease. Neurology 2004;62:357-8.

51. Passey S. Gene mutation detected in Parkinson's disease. Lancet Neurol 2005;4:142-3.

52. Siva N. A new start for Parkinson's disease? Lancet Neurol 2006;5:24-5.

53. Paisán-Ruiz C, Jain S, Evans EW, et al. Cloning of the gene containing mutations that cause PARK8-linked Parkinson's disease. Neuron 2004;44:595-600.

54. Brice A. Genetics of Parkinson's disease: LRRK2 on the rise. Brain 2005;128:2760-2.

55. Agorogiannis EI, Agorogiannis GI, Papadimitriou A, Hadjigeorgiou GM. Protein misfolding in neurodegenerative diseases. Neuropathol Appl Neurobiol 2004;30:215-24.

56. Dawson TM, Dawson VL. Molecular pathways of neurodegeneration in Parkinson`s disease. Science 2003;302:819-22.

57. Eblan MJ, Walker JM, Sidranski E. The glucocerebrosidase gene and Parkinson's disease in Ashkenazi Jews. N Engl J Med 2005;352:728-31.

58. Braak H, Del Tredici K, Rub U, de Vos RA, Jansen Steur EN, Braak E. Neurobiol Aging 2003;24:197-211.

59. Lotharius J, Brundin P. Pathogenesis of Parkinson's disease: dopamine vesicles and $\alpha$-synuclein. Nat Rev Neurosci 2002;3:932-42.

60. Sharon R, Bar-Joseph I, Frosch MP, Walsh DM, Hamilton JA, Selkoe DJ. The formation of highly soluble oligomers of $\alpha$-synuclein is regulated by 
fatty acids and enhanced in Parkinson's disease. Neuron 2003;37:583-95.

61. Sidransky E. Gaucher disease: complexity in a "simple" disorder. Mol Genet Metab 2004;83:6-15.

62. Scriver CR, Beaudet AL, Sly WS, Valle D, Childs B, Kinzler KW, Vogelstein B. The metabolic and molecular basis of inherited disease. $8^{\text {th }}$ edition. New York: McGraw-Hill; 2001.

63. Brady RO. Gaucher's disease: past, present and future. Baillieres Clin Haematol 1997;10:621-34.

64. Bembi B, Zambito Marsala S, Sidransky E, et al. Gaucher's disease with Parkinson's disease: clinical and pathological aspects. Neurology 2003;61:99101.

65. Jankovic J, Tolosa E. Parkinson's disease and movement disorders. $4^{\text {th }}$ edition. Philadelphia: Lippincott, Williams \& Wilkins; 2002.

66. Rosemberg, S. Neuropediatria. $1^{\text {a }}$ edição. São Paulo: Sarvier; 1998.

67. Grabowski GA. Gaucher disease: lessons from a decade of therapy. J Pediatr 2004; 144:S15-S19.

68. Charrow, J, Andersson, HC, Kaplan P, et al. The Gaucher registry: demographics and disease characteristics of 1698 patients with Gaucher disease. Arch Intern Med 2000;160:2835-43

69. Schueler H, Kolter T, Kaneski CR, Zibzow GC, Sandhoff K, Brady RO. Correlation between enzyme activity and substrate storage in a cell culture model system for Gaucher disease. J Inherit Metab Dis 2004;27:649-58.

70. Koprivica V, Stone DL, Park JK, et al. Analysis and classification of 304 mutant alleles in patients with type 1 and type 3 Gaucher disease. Am J Hum Genet 2000;66:1777-86.

71. Goker-Alpan O, Schiffmann R, Park JK, Stubblefield BK, Tayebi N, Sidransky E. Phenotypic continuum in neuronopathic Gaucher disease: an intermediate phenotype between type 2 and type 3. J Pediatr 2003;143:273-6.

72. Grace ME, Ashton-Prolla P, Pastores GM, Soni A, Desnick RJ. Nonpseudogene-derived complex acid $\beta$-glucosidase mutations causing mild type 1 and sever type 2 Gaucher disease. J Clin Invest 1999;103:817-23.

73. Strasberg PM, Triggs-Raine BL, Warren IB, et al. Genotype-phenotype pitfalls in Gaucher disease. J Clin Lab Anal 1994;8:228-36.

74. Germain DP.Gaucher's disease:a paradigm for interventional genetics. Clin Genet 2004:65:77-86.

75. Lwin A, Orvisky E, Goker-Alpan O, LaMarca ME, Sidransky E. Glucocerebrosidase mutations in subjects with parkinsonism. Mol Genet 
Metab 2004;81(1):70-3.

76. Di Rocco M, Allegri AEM, Grossi S, Filocamo M. Gaucher disease phenotype. J Pediatr 2004;145:860.

77. Charrow, J, Andersson, HC, Kaplan P, et al. Enzyme replacement therapy and monitoring for children with type 1 Gaucher disease: consensus recommendations. J Pediatr 2004;144:112-20.

78. Aharon-Peretz J, Badarny S, Rosenbaum H, Geshoni-Baruch R. Mutations in the glucocerebrosidase gene and Parkinson disease: phenotype-genotype correlation. Neurology 2005;65:1460-1.

79. Neudorfer O, Giladi N, Elstein D, et al. Occurrence of Parkinson's syndrome in type I Gaucher disease. QJM. 1996;89:691-4.

80. Cox TM. Gaucher's disease - an exemplary monogenic disorder. QJM 2001;94:399-402.

81. Mendonça VF, Paula MTM, Fernandes C, Boasquevisque EM. Manifestações esqueléticas na doença de Gaucher. Radiol Bras 2001;34:151-4.

82. Behrman RE, Kliegman RM, Jenson HB. Nelson Textbook of Pediatrics. $17^{\text {th }}$ edition. Philadelphia: Saunders; 2004.

83. McKeran RO, Bradbury P, Taylor D, Stern G. Neurological involvement in type 1 (adult) Gaucher's disease. J Neurol Neurosurg Psychiatry 1985;48:172-5.

84. Brady RO. Enzyme replacement for lysosomal diseases. Annu Rev Med 2006;57:283-96.

85. Charrow, J, Esplin JA, Gribble TJ, et al. Gaucher disease: recommendations on diagnosis, evaluation, and monitoring. Arch Intern Med 1998;158:175460.

86. Richards B, Skoletsky J, Shuber AP, et al. Multiplex PCR amplification from the CFTR gene using DNA prepared from buccal brushes/swabs. Hum Mol Genet 1993;2:159-63.

87. Martinez-Arias R, Comas D, Mateu E, Bertranpetit J. Glucocerebrosidase pseudogene variation and Gaucher disease: recognizing pseudogene tracts in GBA alleles. Hum Mutat 2001;17:191-8.

88. Tayebi N, Stubblefield BK, Park JK, et al. Reciprocal and nonreciprocal recombination at the glucocerebrosidase gene region: implications for complexity in Gaucher disease. Am J Hum Genet 2003;72:519-34.

89. Monfort M, Chabás A, Vilageliu L, Grinberg D. Functional analysis of 13 GBA mutant alleles identified in Gaucher disease patients: pathogenic changes and "modifier" polymorphisms. Hum Mutat 2004;23:567-75. 
90. Park JK, Tayebi N, Stubblefield BK, et al. The E326K mutation and Gaucher disease: mutation or polymorphism? Clin Genet 2002;61:32-4.

91. Brady RO, Schiffman R. Enzyme replacement therapy for metabolic storage disorders. Lancet Neurol 2004;4:752-6.

92. Beutler E. Lysosomal storage disorders: natural history and ethical and economic aspects. Mol Genet Metab 2006;88:208-15.

93. Weinreb NJ, Charrow J, Andersson HC, et al. Effectiveness of enzyme replacement therapy in 1028 patients with type 1 Gaucher disease after 2 to 5 years of treatment: a report from the Gaucher registry. Am J Med 2002;113:112-9.

94. Van Bogaert, LF. Un cas de maladie de Gaucher de l'adulte avec syndrome de Raynaud,pigmentation,et rigidite du type extra-pyrajidal aux membres inferieurs. Ann Med 1939;45:57-70.

95. Machaczka M, Rucinska M, Skotnicki AB, Jurczak W Parkinson's syndrome preceding clinical manifestation of Gaucher's disease. Am J Hematol 1999;61:216-7.

96. Tayebi N, Walker J, Stubblefield B, et al. Gaucher disease with parkinsonian manifestations: does glucocerebrosidase deficiency contribute to a vulnerability to parkinsonism? Mol Genet Metab. 2003;79:104-9.

97. Spitz M, Rozenberg R, Silveira PAA, Barbosa ER. Parkinsonism in type 1 Gaucher's disease. J Neurol Neurosurg Psychiatry 2006;77:709-10.

98. Várkonyi J, Rosenbaum H, Baumann N, et al. Gaucher disease associated with parkinsonism: four further case reports. Am J Med Genet 2003;116A:348-51.

99. Várkonyi J, Simon Z, Soos K, Poros A. Gaucher disease type I complicated with Parkinson's syndrome. Haematologia (Budap) 2002;32:271-5.

100. Grewal RP, Doppelt SH, Thompson MA, Katz D, Brady RO, Barton NW. Neurologic complications of non-neuronopathic Gaucher's disease. Arch Neurol 1991;48:1271-2.

101. Zimran A, Neudorfer O, Elstein D. The glucocerebrosidase gene and Parkinson's disease in Ashkenazi Jews. N Engl J Med 2005;352:728-31.

102. Goker-Alpan O, Schiffmann R, LaMarca ME, Nussbaum RL, McInerney-Leo A, Sidransky E. Parkinsonism among Gaucher disease carriers. J Med Genet 2004;41:937-40.

103. Clark L, Nicolai A, Afridi S, et al. Pilot association study of the $\beta$ glucocerebrosidase N370S allele and Parkinson's disease in subjects of Jewish ethnicity. Mov Disord 2005;20:100-3. 
104. Sato C, Morgan A, Lang AE, et al. Analysis of glucocerebrosidase gene in Parkinson's disease. Mov Disord 2005;20:367-70.

105. Eblan MJ, Nguyen J, Ziegler SG, et al. Glucocerebrosidase mutations are also found in subjects with early-onset parkinsonism from Venezuela. Mov Disord 2006;21:282-3.

106. Hughes AJ, Daniel SE, Kilford L, Lees AJ. Accuracy of clinical diagnosis of idiopathic Parkinson's disease: a clinico-pathological study of 100 cases. J NeurolNeurosurg Psychiatr 1992;55:181-4.

107. Hughes AJ, Daniel SE, Ben-Shlomo Y, Lees AJ. The accuracy of diagnosis of parkinsonian syndromes in a specialist movement disorder service Brain 2002;125:861-70.

108. Hardy J, Cookson MR, Singleton A. Genes and parkinsonism. Lancet Neurol 2003;2:221-8.

109. DeStefano AL, Golbe LI, Mark MH, et al. Genome-wide scan for Parkinson's disease: The GenePD study. Neurology 2001;57:1124-6.

110. Decol RD. Judeus no Brasil: explorando os dados censitários. RBCS 2001;16:147-60.

111. Rozenberg R, Araújo FT, Fox DC, et al. High frequency of mutation G377S among type 3 Gaucher disease Brazilian patients. Br J Med Biol Res. In press.

112. Lyons, RH. A molecular biology glossary. University of Michigan. Jul 1998. Available from: http://seqcore.brcf.med.umich.edu/doc/educ/dnapr/ mbglossary/ mbgloss.html

113. Henry, JB. Clinical diagnosis and management by laboratory methods. $20^{\text {th }}$ ed. Philadelphia :WB Saunders;2001.

114. Eppig JT, Levan G. Rules for nomenclature of genes, genetic markers, alleles, and mutations in mouse and rat. Jan 2005. Available from: http://www.informatics.jax.org/mgihome/nomen/gene.shtml

115. Michelin K, Wajner A, de Souza FT. Application of a comprehensive protocol for the identification of Gaucher disease in Brazil. Am J Med Genet 2005;136:58-62.

116. Chien HF, Rohé CF, Costa MD, et al. Early-onset Parkinson`s disease caused by a novel parkin mutation in a genetic isolate from northeastern Brazil. Neurogenetics 2006;7:13-9.

117. Di Fonzo A, Tassorelli C, De Mari M, et al. Comprehensive analysis of the LRRK2 gene in sixty families with Parkinson`s disease. Eur J Hum Genet 2006; 14:322-31. 
118. Di Fonzo A, Rohé CF, Chien HF, et al. A frequent LRRK2 gene mutation associated with autosomal dominant Parkinson`s disease. Lancet 2005;365:412-5.

119. Perez-Calvo J, Bernal M, Giraldo P, et al. Co-morbidity in Gaucher's disease results of a nationwide enquiry in Spain. Eur J Med Res 2000;20:2315.

120. Brugg B, Michel PP, Agid Y, Ruberg M. Ceramide induces apoptosis in cultured mesencephalic neurons. $J$ Neurochem 1996;66:733-9.

121. Feany M. New Genetic Insight sinto Parkinson's disease. $N$ Engl J Med 2004;351:1937-40.

122. Wong K, Sidransky E, Verma A, et al. Neuropathology provides clues to the pathophysiology of Gaucher disease. Mol Genet Metab 2004;82:192207.

123. Bussell R, Eliezer D. Effects of Parkinson's disease-linked mutations on the structure of lipid-associated $\alpha$-synuclein. Biochemistry 2004;43:48108.

124. Schlossmacher MG, Cullen V, Muthing J. The glucocerebrosidase gene and Parkinson's disease in Ashkenazi Jews. $N$ Engl $J$ Med 2005;352:728-31.

125. Halperin A, Elstein E, Zimran A. Increased incidence of Parkinson disease among relatives of patients with Gaucher disease. Blood Cells, Mol and Dis 2006;36:426-8.

126. Hughes AJ, Ben-Shlomo Y, Daniel SE, Lees AJ. What features improve the accuracy of clinical diagnosis in Parkinson's disease: a clinicopathologic study. Neurology 1992;42:1142-6.

127. Hughes AJ, Daniel SE, Lees AJ. Improved accuracy of clinical diagnosis of Lewy body Parkinson's disease. Neurology 2001;57:1497-9.

128. Uitti RJ, Calne DB, Dickson DW, Wszolek ZK. Is the neuropathological 'gold standard' diagnosis dead? Implications of clinicopathological findings in an autosomal dominant neurodegenerative disorders. Parkinsonism Relat Disord 2004;10:461-3.

129. Baba Y, Uitti RJ. Fragile X-associated tremor/ataxia syndrome and movements disorders. Curr Opin Neurol 2005;18:393-8. 
130. Goker-Alpan O, Giasson BI, Eblan BA, et al. Glucocerebrosidase mutations are an important risk factor for Lewy body disorders. Neurology 2006;67:1-3.

131. Spitz M, Barbosa ER. Parkinsonismo em pacientes com doença de Gaucher. Rev Bras de Neurol 2005;41:5-10.

132. Sidransky E. Gaucher disease and parkinsonism. Mol Genet Metab 2005;84:302-4. 